UNIVERSIDADE DE SÃO PAULO

FACULDADE DE EDUCAÇÃO

JENNIFER STEPHANIE MONJE MARIN

Políticas públicas de educação infantil no Chile e no Brasil:

tensões e tendências sobre a gestão municipal como eixo de qualidade 
Políticas públicas de educação infantil no Chile e no Brasil: tensões e tendências sobre a gestão municipal como eixo de qualidade

\section{Versão Original}

Dissertação apresentada ao Programa de Pós-Graduação em Educação da Faculdade de Educação da Universidade de São Paulo, para a obtenção do grau de Mestre em Educação.

Área de Concentração: Educação e Ciências Sociais, Desigualdades e Diferencias.

Linha de Pesquisa: Sociologia da Educação

Orientadora: Profa. Dra. Maria Letícia Barros Pedroso Nascimento. 
AUTORIZO A REPRODUÇÃO E DIVULGAÇÃO TOTAL OU PARCIAL DESTE TRABALHO, POR QUALQUER MEIO CONVENCIONAL OU ELETRÔNICO, PARA FINS DE ESTUDO E PESQUISA, DESDE QUE CITADA A FONTE.

Catalogação na Publicação

Serviço de Biblioteca e Documentação

Faculdade de Educação da Universidade de São Paulo

372

M337p
Marin, Jennifer Stephanie Monje

Políticas públicas de educação infantil no Chile e no Brasil: tensões e tendências sobre a gestão municipal como eixo de qualidade / Jennifer Stephanie Monje Marin; orientação Maria Letícia Barros Pedroso Nascimento. São Paulo: s.n., 2017.

$$
145 \text { p.; grafs.; tabs. }
$$

Dissertação (Mestrado - Programa de Pós-Graduação em Educação. Área de Concentração: Sociologia da Educação) - Faculdade de Educação da Universidade de São Paulo.

1. Educação infantil 2. Educação (Reforma) 3. Qualidade da educação I. Nascimento, Maria Letícia Barros Pedroso, orient. 
Esta conquista é para você, Carmen, vovozinha amada. 


\section{AGRADECIMENTOS}

Os agradecimentos são um dos últimos e mais difíceis momentos da escrita de um trabalho como este, especialmente para aqueles que, como eu, decidiram sair do próprio país e se enriquecer de novas experiências, aprendizados, contextos e pessoas, aquelas que sabem que, sem seu apoio e ajuda, esta dissertação não teria sido possível. Assim, com meu mais profundo respeito, consideração e reconhecimento, agradeço:

A minha orientadora, Prof ${ }^{a}$. Dr ${ }^{a}$. Maria Letícia Nascimento, por acompanhar-me com competência e dedicação, por acreditar em mim e no meu trabalho e por me ensinar, com o seu exemplo, a ser uma profissional comprometida e humana.

À FEUSP e aos seus funcionários da secretaria de pós-graduação, por terem respondido todas minhas perguntas e me outorgarem a assistência necessária como estudante estrangeira.

Às minhas duas queridas famílias, "a de lá e a de aqui”. Meus pais, Carlos e Yolanda, minha irmã Melanie, meu irmão Cristóbal, vovô, primos (as) e tios (as), que, desde o Chile, sempre tem apoiado meus estudos e me motivado a confiar nas minhas escolhas. À família brasileira Pedreira-Perazzo, por me acolher como uma integrante a mais e me dar forças para continuar neste caminho.

Ao Fernando, por ser quem é, companheiro fiel de batalhas e aventuras. Com você ao meu lado, todo desafio parece ser bem mais simples.

Às professoras doutoras Lisete Regina Gomes Arelaro (FEUSP), Maria Carmen Silveira Barbosa (UFRGS) e Célia Regina Batista Serrão (UP Mackenzie) por terem aceitado gentilmente o convite para participar da banca de qualificação e pelas valiosas contribuições das duas primeiras professoras na minha qualificação.

Aos professores e colegas do Mestrado, pela fonte rica de aprendizagens, discussões e reflexões durante todo o curso.

Aos colegas do GEPSI pelo acolhimento e incentivo, por me mostrarem o maravilhoso campo da Sociologia da Infância e seu desenvolvimento no Brasil. Homens e mulheres que têm minha mais profunda admiração.

Ao CNPq pela concessão da bolsa para que eu pudesse realizar esta dissertação.

Aos meus amigos e amigas, os de sempre e os de hoje, a todos vocês, meu carinho especial e minha gratidão. 


\section{RESUMO}

Monje Marin, J. S. Políticas públicas de educação infantil no Chile e no Brasil: tensões e tendências sobre a gestão municipal como eixo de qualidade. 2017. 145 f. Dissertação (Mestrado em Educação) - Faculdade de Educação, Universidade de São Paulo, São Paulo, 2017.

Atualmente, no Chile, experimenta-se uma reforma educacional que pretende repercutir no entendimento e gestão da Educação Infantil de qualidade, alinhada coerentemente com os cenários locais e estabelecendo a responsabilização e a participação da gestão municipal como fatores de qualidade. $\mathrm{Na}$ busca de experiências que possam apoiar essas mudanças, desperta o interesse em entender outra forma de planejamento e aplicação de políticas públicas de Educação Infantil num país com um modelo de gestão educativa distinto, como é o caso do Brasil. Baseada nos fundamentos da Educação Comparada, esta dissertação descreve, explora e compara a configuração de políticas públicas contemporâneas de Educação Infantil formalizadas pelos Estados do Brasil e do Chile, na sua relação - muitas vezes conflituosa com a gestão municipal, a partir de três linhas de teorização: descentralização da educação, qualidade da Educação Infantil e responsabilização educativa, para compreender as tensões, implicações e possibilidades da gestão municipal como eixo de qualidade da Educação Infantil. O entendimento dos dois contextos não apenas permitiu conhecer as nuances do percurso histórico, das formas de organização do Estado e das influências de agencias internacionais que provocaram múltiplas reconstruções nas políticas de Educação Infantil no Chile e no Brasil, aliás, permitiu descobrir os nexos entre dois sistemas educativos muitas vezes apresentados como diferentes. Com base nas avaliações de políticas nacionais, legislações e pesquisas realizadas em cada país, assim como em documentos internacionais que situam ambos os países na contingência latino-americana, foi possível identificar um conjunto de convergências e divergências na configuração de políticas públicas, principalmente destacando a emergência de novas formas de equação entre participação e responsabilização tanto das esferas nacionais de governo, quanto das locais. Embora as políticas chilenas e brasileiras registrem uma serie de semelhanças e algumas significativas diferencias, o certo é que, atualmente, nos dois países existe uma tendência baseada na "responsabilização mista" entre as autonomias locais e as regulações do Estado como fator de qualidade na Educação Infantil. Dentre as conclusões, destaca-se a "negociabilidade" que a qualidade da Educação Infantil está adquirindo em ambos os países e o perfil da gestão municipal como mobilizador e canalizador da construção e avaliação da Educação Infantil. Através de um discurso eclético que concebe a educação de infância como função que compete a uma sociedade participativa, também destaca-se o papel de um Estado ativo que oriente, apoie e integre as gestões municipais e os centros educativos para a abordagem do tema da qualidade da Educação Infantil como um processo social complexo, multifatorial e de construção permanente onde os primeiros agentes da busca dessa qualidade sejam as próprias comunidades educativas, tendência que traz novos paradoxos para a Educação Infantil nos países estudados, não obstante, também permite indicar algumas considerações que possam contribuir ao cenário de reformas no Chile.

Palavras-chave: Educação Infantil, reformas educacionais, descentralização, qualidade, responsabilização, qualidade negociada. 


\section{RESUMEN}

Monje Marin, J. S. Políticas públicas de educação infantil no Chile e no Brasil: tensões e tendências sobre a gestão municipal como eixo de qualidade. 2017. 145 f. Dissertação (Mestrado em Educação) - Faculdade de Educação, Universidade de São Paulo, São Paulo, 2017.

Actualmente en Chile, se vive una reforma educacional que pretende repercutir en el entendimiento y gestión de la Educación Infantil de calidad, alineada coherentemente con los escenarios locales y estableciendo la responsabilización y participación de la gestión municipal como factores de calidad. En la búsqueda de experiencias que puedan apoyar estos cambios, despierta el interés por entender otra forma de planificación y aplicación de políticas públicas de Educación Infantil, en un país con un modelo de gestión educativa distinto, como es el caso de Brasil. Basada en los fundamentos de la Educación Comparada, esta disertación describe, explora y compara la configuración de políticas públicas contemporáneas de Educación Infantil formalizadas por los Estados de Brasil y Chile, en su relación -muchas veces conflictiva- con la gestión municipal, a partir de tres líneas de teorización: descentralización de la educación, calidad de la Educación Infantil y responsabilización educativa, para comprender las tensiones, implicaciones y posibilidades de la gestión municipal como eje de calidad de la Educación Infantil. El entendimiento de los dos contextos no solo permitió conocer los matices del recorrido histórico, de las formas de organización del Estado e de las influencias de agencias internacionales que provocaron múltiples reconstrucciones en las políticas de Educación Infantil en Chile y en Brasil, además, permitió descubrir los nexos entre dos sistemas educativos muchas veces presentados como diferentes. Con base en las evaluaciones de políticas nacionales, legislaciones e investigaciones realizadas en cada país, así como en documentos internacionales que sitúan ambos países en la contingencia latinoamericana, fue posible identificar un conjunto de convergencias y divergencias en la configuración de políticas públicas de Educación Infantil, principalmente destacando la emergencia de nuevas formas de ecuación entre participación y responsabilización, tanto de las esferas nacionales de gobierno, como de las locales. Aunque las políticas chilenas y brasileras registren una serie de semejanzas y algunas significativas diferencias, lo cierto es que, actualmente, en los dos países existe una tendencia basada en la "responsabilización mixta" entre las autonomías locales y las regulaciones del Estado, como factor de calidad de la Educación Infantil. Entre las conclusiones, se destaca la "negociabilidad" que la calidad de la Educación Infantil está adquiriendo en ambos países y el perfil de la gestión municipal como movilizadora y canalizadora de la construcción y evaluación de la Educación Infantil. A través de un discurso ecléctico que concibe la educación de infancia como función que compete a una sociedad participativa, también se destaca el papel de un Estado activo que oriente, apoye e integre las gestiones locales y los centros educativos para el abordaje del tema de la calidad de la Educación Infantil como un proceso social complejo, multifactorial y de construcción permanente donde los primeros agentes de búsqueda de esa calidad sean las propias comunidades educativas, tendencia que trae nuevas paradojas para la calidad de la Educación Infantil en los países estudiados, no obstante, también permite indicar algunas consideraciones que puedan contribuir al escenario de reformas en Chile.

Palabras claves: Educación Infantil, reformas educacionales, descentralización, calidad, responsabilización, calidad negociada. 


\begin{abstract}
Monje Marin, J. S. Políticas públicas de educação infantil no Chile e no Brasil: tensões e tendências sobre a gestão municipal como eixo de qualidade. 2017. 145 f. Dissertação (Mestrado em Educação) - Faculdade de Educação, Universidade de São Paulo, São Paulo, 2017.
\end{abstract}

Currently in Chile, there is an educational reform that aims to reflect on the understanding and management of quality child education. This reform pursues to be aligned with local scenarios, establishing the responsibility and the participation of municipal management as the two main quality factors. In the search for experiences that can support these changes, it arouses the interest to understand another form of planning and implementation of public policies of ECE in a country with a different educational management model, as Brazil. Based on the foundations of Comparative Education, this dissertation describes, explores and compares the configuration of contemporary public policies of ECE formalized by both the states of Brazil and Chile, in their - often conflictive -relationship with municipal management, starting from three theorization lines: educational decentralization, quality of ECE, and educational accountability. The aim is to understand the tensions, implications and possibilities of municipal management as the quality axis of ECE. The understanding of the contexts of Brazil and Chile allowed to know the nuances of the historical journey, the forms of State organization and the influences of the multinational agencies that provoked multiple reconstructions in the policies of ECE in both countries. This analysis also showed the links between two educational systems often presented as different ones. Based on the assessments of national policies, legislation and research carried out in both countries, as well as on international documents that place both countries in the Latin American contingency, it was possible to identify a set of convergences and divergences in the configuration of public policies of ECE. As a result, new forms of equation between participation and accountability, both in the national and local spheres of government were highlighted. Although Chilean and Brazilian policies record many similarities and some significant differences, the fact is that, in the two countries, there is a trend based on a kind of "mixed responsibility" between local autonomies and state regulations, as the quality axis of ECE. Among the most important conclusions of the study are the "negotiability" that the quality of ECE is acquiring in both countries, and the profile of municipal management as a mobilizer and channel for the construction and evaluation of quality Child Education. The eclectic discourse that conceives childhood education as a function of a participatory society highlights the role of an active State that guides, supports and integrates local efforts and educational centers to address the issue of quality of ECE. In this sense, the latter is understood as a complex, multifactorial and permanent social process where the first search agents of this quality are the educational communities themselves, a trend that brings new paradoxes to the quality of ECE in the countries studied. However, it also allows to indicate some considerations that may contribute to the scenario of reforms in Chile.

Key words: Early Childhood Education, Educational Reforms, Decentralization, Educational Quality, Accountability, Negotiated Quality 


\section{LISTA DE TABELAS E GRÁFICOS}

\begin{tabular}{|l|c|}
\hline $\begin{array}{l}\text { Tabela 1 - Instituições Responsáveis pela Educação Infantil Pública } \\
\text { Chilena }\end{array}$ & 45 \\
\hline Tabela 2 - Componentes e Categorias de Organização Curricular (Chile) & 50 \\
\hline $\begin{array}{l}\text { Gráfico 3 - Evolução da taxa de cobertura nacional de EI por faixa etária } \\
\text { em Chile (\%) 1990-2013 }\end{array}$ & 61 \\
\hline $\begin{array}{l}\text { Gráfico 4- Evolução da cobertura nacional de EI por quintil de ingresso } \\
\text { autônomo em Chile (\%) 1990-2011 }\end{array}$ & 61 \\
\hline $\begin{array}{l}\text { Tabela 5- Evolução da cobertura nacional de EI por região em Chile (\%) 1990- } \\
\text { 2011 }\end{array}$ & 62 \\
\hline $\begin{array}{l}\text { Gráfico 6 - Evolução do número de matrículas na pré-escola segundo } \\
\text { dependência administrativa em Chile - 1990-2013 }\end{array}$ & 62 \\
\hline $\begin{array}{l}\text { Gráfico 7- Evolução do gasto público nacional em EI em Chile 1990-2013 (por } \\
\text { milhões de pesos) }\end{array}$ & 63 \\
\hline $\begin{array}{l}\text { Gráfico 8- Evolução da frequência de crianças em instituições de EI por } \\
\text { faixa etária, Brasil, (\%) 1995 - 2013 }\end{array}$ & 92 \\
\hline $\begin{array}{l}\text { Gráfico 9 - Porcentagem de crianças de 0 a 3 anos que frequentam instituições } \\
\text { de EI - Brasil - 1995-2011, por unidades da federação e regiões metropolitanas }\end{array}$ & 92 \\
\hline $\begin{array}{l}\text { Gráfico 10 - Porcentagem de crianças de 4 a 5 anos que frequentam } \\
\text { instituições de EI- Brasil - 1995-2011, por unidades da federação e regiões } \\
\text { metropolitanas }\end{array}$ & 93 \\
\hline $\begin{array}{l}\text { Tabela 11 - Número de matrículas por dependência administrativa da pré- } \\
\text { escola, Brasil, anos escolhidos }\end{array}$ & 100 \\
\hline $\begin{array}{l}\text { Tabela 12 - Número de matrículas por dependência administrativa da creche, } \\
\text { Brasil, anos escolhidos }\end{array}$ & 93 \\
\hline $\begin{array}{l}\text { Tabela 13- Indicadores econômicos, sociais e demográficos, Brasil e } \\
\text { Chile (2014) }\end{array}$ & 99 \\
\hline $\begin{array}{l}\text { Tabela 14 - Panorama geral dos níveis educacionais, Brasil e Chile } \\
\text { (2016) }\end{array}$ & $\begin{array}{l}\text { Tabela 15- Evolução da taxa de Cobertura de EI (\%) Brasil e Chile, por } \\
\text { faixa etária - anos escolhidos }\end{array}$ \\
\hline $\begin{array}{l}\text { Gráfico 16 -Taxa de cobertura de “escolarização" em EI de crianças de 2 a 5 } \\
\text { anos, segundo indicadores OCDE 2014 }\end{array}$ \\
$\begin{array}{l}\text { Tabela 17 - Evolução da taxa de Cobertura de EI por apenas } \\
\text { dependência municipal (\%) Brasil e Chile - anos escolhidos }\end{array}$ \\
\hline
\end{tabular}




\section{LISTA DE SIGLAS E ABREVIAÇÕES}

BCEP - Bases Curriculares de la Educación Parvularia (Chile)

BID - Banco Interamericano de Desenvolvimento

$\mathrm{BM}$ - Banco Mundial

CDC - Convenção sobre os Direitos da Crianca

CEPAL - Comissão Econômica para América Latina e o Caribe

CF - Constituição Federal (Brasil)

ChCC - Chile Crece Contigo (Chile)

CPEIP - Centro de Perfeccionamiento, Experimentación e Investigación Pedagógica

COEDI - Coordenação de Educação Infantil (Brasil)

DAEM - Departamento de Educación Municipal (Chile)

EB - Educação Básica (Brasil)

EC - Educação Comparada

ECA - Estatuto da Criança e do Adolescente (Brasil)

EI - Educação Infantil

FCC - Fundação Carlos Chagas (Brasil)

FUNACO - Fundación Nacional de Ayuda a la Comunidad (Chile)

FUNDEB - Fundo de Manutenção e Desenvolvimento da Educação Básica e de Valorização dos Profissionais da Educação (Brasil)

FUNDEF - Fundo de Manutenção e Desenvolvimento do Ensino Fundamental e de Valorização do Magistério (Brasil)

JUNJI - Junta Nacional de Jardines Infantiles (Chile)

IBGE - Instituto Brasileiro de Geografia e Estatística

INEP - Instituto Nacional de Estudos e Pesquisas Educacionais Anísio Teixeira (Brasil)

LDB - Lei de Diretrizes e Bases da Educação Nacional (Brasil)

LOCE - Ley Orgánica Constitucional de Enseñanza (Chile)

LRF - Lei de Responsabilidade Fiscal (Brasil)

MARE - Ministério da Administração e Reforma do Estado (Brasil)

MEC - Ministério de Educação (Brasil)

MIEIB - Movimento Interfóruns de Educação Infantil do Brasil

MINEDUC - Ministerio de Educación (Chile)

OCDE - Organização para a Cooperação e Desenvolvimento Económico

OMEP - Organização Mundial para a Educação Pré-escolar

ONU - Organização das Nações Unidas

PNE - Plano Nacional de Educação (Brasil)

PPP - Propostas Pedagógicas e Projetos Políticos Pedagógicos

PSU - Prueba de Selección Universitaria (Chile)

UNESCO - Organização das Nações Unidas Educação, Ciência e a Cultura

UNICEF - Fundo das Nações Unidas para a Infância

VTF - Via Transferencia de Fondos (Chile) 


\section{SUMÁRIO}

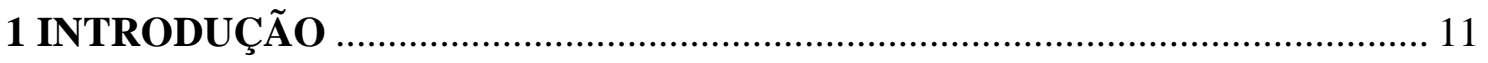

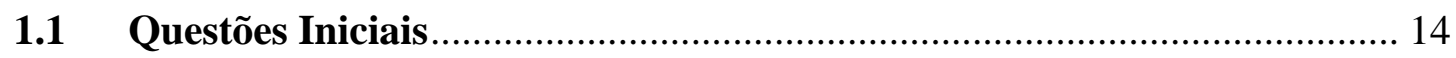

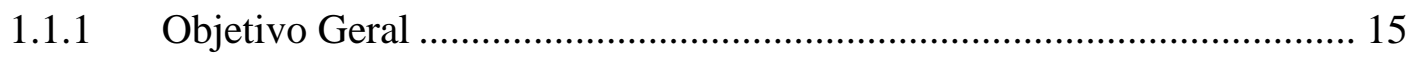

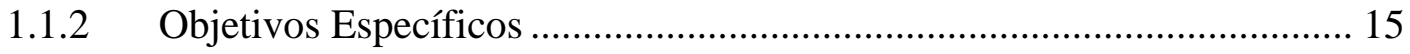

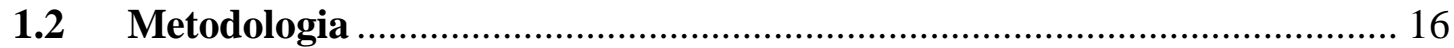

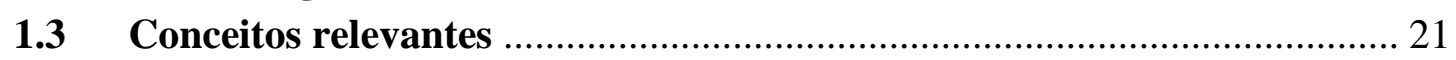

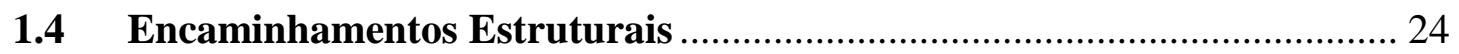

2 A CONFIGURAÇÃO DAS POLÍTICAS DE EDUCAÇÃO INFANTIL NO CHILE E NO BRASIL: CONTEXTO SUL-AMERICANO, MARCOS LEGAIS, PERCURSOS E

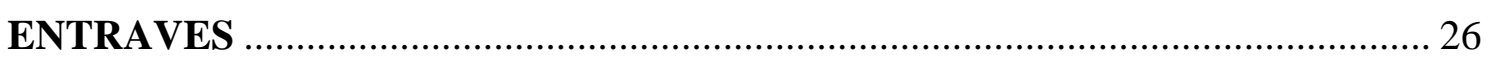

2.1 O ajuste estrutural e a EI como superação da pobreza da América do Sul .. 27

2.1.1 O direito das crianças à Educação ................................................................ 32

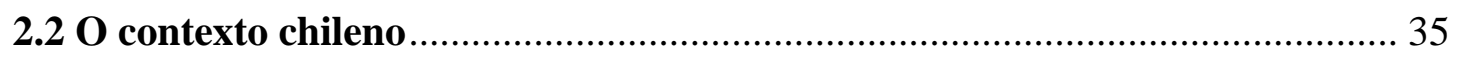

2.2.1 Educação Infantil chilena na ditadura (1973-1990) ...................................... 36

2.2.2 O Estado Compensatório (1990-2005)....................................................... 42

2.2.3 Século XXI: A Era do Estado Vigilante (2006 - 2014) ................................ 53

2.2.4 Estatísticas e conclusões preliminares ......................................................... 61

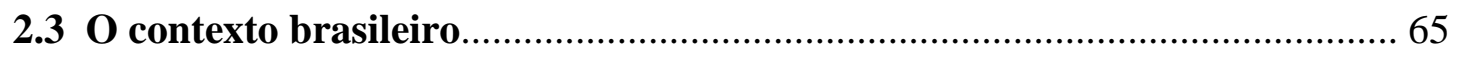

2.3.1 O regime militar e a posterior abertura democrática da EI (1964-1994) ....... 66

2.3.2 A Reforma do Estado e a LDB (1994-2001) ................................................. 73

2.3.3 O governo Lula e a definição de qualidade................................................ 81

2.3.4 Estatísticas e conclusões preliminares ..................................................... 92

3 EDUCAÇÃO INFANTIL NO CHILE E NO BRASIL EM BUSCA DE QUALIDADE:

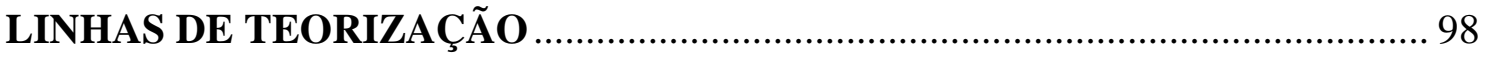

3.1 Educação Infantil chilena e brasileira frente aos fundamentos de descentralização educativa............................................................................. 104

3.2 Educação Infantil chilena e brasileira frente aos princípios atuais de qualidade

3.3 Educação de infância chilena e brasileira frente aos modelos da responsabilização educativa para a qualificação da Educação Infantil....... 119

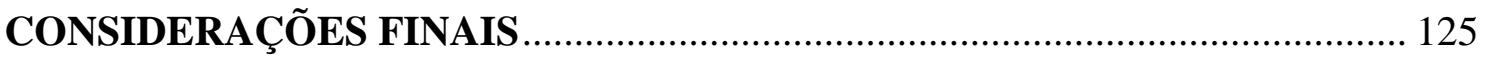

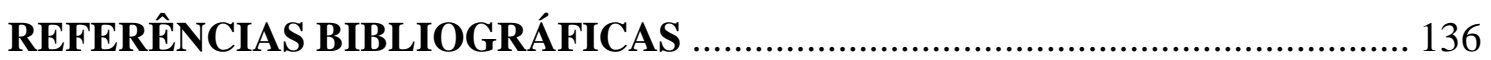




\section{INTRODUÇÃO}

Nas últimas décadas, produziram-se mudanças, tanto locais como mundiais, que alteraram a visão e a concepção de infância e de Educação Infantil. A ideia de crianças como sujeitos de direito, consagrada em 1990 pela Convenção Internacional dos Direitos da Criança $(\mathrm{CDC})^{1}$, estabelece um novo paradigma que rege a relação entre sociedade, Estado, família e crianças como parte de um processo democrático de reconhecimento e convivência social. $\mathrm{O}$ documento inclui normativas em torno dos direitos de provisão, proteção e participação das crianças, com vistas a garantir que a ação governamental das nações, após a ratificação da CDC, esteja empenhada em cobrir, de forma abrangente, a realização dos princípios nela contidos, criando políticas que permitam o bem-estar das crianças desde o nascimento, além de promover medidas de redução das desigualdades de crianças em situações vulneráveis.

$\mathrm{Na}$ América do Sul, a maioria dos países tem instaurado sistemas de atenção às crianças nos quais a Educação Infantil é uma estratégia importante, convertida inclusive numa bandeira política para evidenciar o compromisso dos governos com as suas crianças e com os princípios internacionais de educação e atendimento. Esse envolvimento, porém, nem sempre dependeu apenas da CDC, e sim de uma crescente intervenção de organismos internacionais que, ao longo do século XX, estabeleceram diretrizes e programas de ação conjunta com os Estados nacionais, como forma de responsabilização pela erradicação da pobreza e pela falta de oportunidades educativas que afeta, até hoje, grande parte de crianças no mundo, especialmente no continente latino-americano. Cabe destacar que a relação de dependência entre países remonta à década de 1970, quando as orientações do paradigma do capitalismo internacional agravaram o endividamento externo da maioria dos Estados da América Latina e Caribe, provocando a redução da capacidade de financiamento e custeio de políticas sociais e comprometendo a capacidade dos governos de fazer frente às necessidades sociais e educacionais. Isso originou uma nova relação dos Estados nacionais com o capitalismo, que os levou a adotar características orientadas pela desregulamentação de suas economias, abertura econômica, perda de equilíbrio fiscal e privatização de empresas e serviços públicos. Os sistemas educativos nacionais, a maioria deles em fase de expansão e consolidação, foram

\footnotetext{
1 A Assembleia Geral das Nações Unidas adotou a Convenção sobre os Direitos da Criança - Carta Magna para as crianças de todo o mundo - em 20 de novembro de 1989, e, no ano seguinte, o documento foi oficializado como lei internacional. A Convenção sobre os Direitos da Criança é o instrumento de direitos humanos mais aceito na história universal. Foi ratificado por 196 países. Atualmente, somente Estados Unidos não ratificou a Convenção.
} 
frontalmente atingidos por políticas com tais características, decorrendo, na maioria dos casos, em contextos dominados por forte burocratização, centralização dos sistemas e desperdício de recursos (ARAÚJO, 2005). Frente a tal diagnóstico, paradoxalmente sustentado também por agências internacionais e apoiado por amplos setores das sociedades locais, foi imposto um conjunto de reformas neoliberais paliativas, as quais foram assumidas pelos governos da maioria dos países. Segundo Araújo (2005), as duas marcas principais de tais reformas foram a redução do poder do Estado e a descentralização da gestão educacional, transferida para governos subnacionais com possibilidades muito heterogêneas e novas exigências que reorganizaram grande parte dos sistemas sociais e educativos.

O caso chileno é um exemplo dessa situação e destaca por suas peculiaridades. No período de 2008 a 2014, em trabalho como assistente técnico-pedagógico de Educação Infantil na Secretaria Municipal de Santiago (capital) e como assistente acadêmica na Universidade do Chile, observou-se tanto as transformações das políticas públicas em Educação Infantil deste país, assim como a realidade das instituições que as implementam. Com base nas estatísticas, podemos dizer que a Educação Infantil chilena alcançou importantes avanços nas últimas três décadas, em temas como organização institucional, gasto público, cobertura e base curricular comum, processos que adquiriram grande importância a partir de 1990, ano em que coincidiram dois acontecimentos marcantes para a pauta das políticas públicas contemporâneas deste país: a participação do Estado numa série de compromissos mundiais em nome da infância e a volta da democracia depois de dezessete anos de ditadura.

Desde então, o foco foi se instalando no direito da criança à educação e que esta educação seja de qualidade, elementos que ganharam consideração nas agendas públicas e supuseram a sua integração a um sistema educativo nacional legitimado constitucionalmente sob arquétipos neoliberalistas. O Chile enfatizou a integração da Educação Infantil ao sistema educativo, com a criação de políticas de acesso que garantem educação desde os primeiros anos de vida em todas as instituições públicas, mas, seguindo a linha de gestão e administração educativa nacional descentralizada, instalada no período ditatorial e formalmente influenciada pelas diretrizes do Banco Mundial: as políticas e os programas são planejados pelo governo central através do Ministério de Educação, enquanto a aplicação e a administração dessas políticas fica como responsabilidade de unidades básicas chamadas Municipalidades (município), ou a cargo de agentes particulares com financiamento público chamados sostenedores (mantenedores). 
No entanto, embora o desenvolvimento das políticas aconteça no âmbito governamental, sua aplicação tem se realizado na esfera local, não isenta de debates e problemáticas. Hoje a Educação Infantil pública chilena forma parte de um sistema educativo segregado e desigual, pois o certo é que, mesmo avançando, existem evidentes tensões entre os objetivos projetados nas políticas públicas de Educação Infantil e a sua implementação local, cuja gestão registra uma incapacidade de se desprender de um modelo educativo fortemente padronizado, dominado por estratégias de mercado e que tem permanecido legalmente sustentado pela Constituição até nossos dias. A partir de 1990, a política de Educação Infantil chilena tem transitado entre sistemas educativos desenhados por governos democráticos de centro-esquerda e de direita, com modelos cada vez mais parecidos aos do Ensino Fundamental e sofisticados através do tempo por princípios internacionais de qualidade e responsabilização educativa, mas também enormemente influenciados por modelos de gerenciamento empresarial. Esse cenário tem provocado grandes rupturas na gestão educativa local, deficiente autonomia administrativa e política, escassas instancias de participação e toma de decisões por parte dos municípios e instituições, padronização de práticas pedagógicas, falta de capacitação das lideranças locais e uma desigualdade territorial comparada às diversidades geográficas, culturais, raciais e sociais ao longo do Chile, que produziu uma segregação desmesurada que centralizou os resultados, os recursos públicos e as melhorias só em alguns contextos, deixando outros em clara desvantagem (OLIVA, 2008).

Para enfrentar essa situação, remanescente há mais de quatro décadas, em 2014 foi aprovada pelo governo chileno uma grande Reforma Educacional, a fim de fazer mudanças legislativas e de gestão educacional, como parte da "Nova Gestão Pública" do governo e para enfrentar a crise educativa desde uma ótica pertinente, que permita aliviar a tensão entre o desenvolvimento das políticas e a sua implementação. Entre os pilares da proposta, se encontram: mudar a organização institucional ou Institucionalidad do ensino público; devolver ao Estado chileno as funções de coordenador e administrador de instituições que hoje dependem de agentes particulares envolvidos com educação pública e; outorgar aos municípios e instituições educativas, instancias de participação, responsabilização e toma de decisões pela adequação das políticas públicas nacionais às realidades específicas e aos projetos educativos próprios.

Este último desafio é muito importante, principalmente porque se espera que as mudanças repercutam na qualidade da Educação Infantil, através de transformações profundas que permitam um alinhamento mais coerente com o cenário local, além de estabelecer a participação e a autonomia da gestão municipal como fator de qualidade da educação. Na 
busca de experiências que possam apoiar as mudanças, desperta o interesse em entender outra forma de planejamento e aplicação de políticas públicas de Educação Infantil num país com um modelo de gestão educativa distinto, também consolidado, como é o caso do Brasil.

Neste trabalho, considera-se importante estudar a configuração da Educação Infantil brasileira, pois, mesmo partilhando algumas similaridades com o Chile, o sistema brasileiro é conhecido em terras chilenas pela promoção da contextualização de políticas públicas nacionais, da gestão democrática e da participação dos municípios e instituições educativas na construção e avaliação da Educação Infantil local, elementos interessantes para explorar e que podem facilitar o entendimento da Reforma Educacional no Chile.

Esta pesquisa não pretende ser uma denúncia nem um elogio para nenhuma das duas sociedades. Espera-se que o texto permita conhecer as nuances do contexto chileno e brasileiro que provocaram múltiplas reconstruções na política de Educação Infantil, assim como oferecer os nexos entre dois sistemas muitas vezes apresentados como diferentes. Com base nas avaliações de políticas nacionais, documentos legislativos e pesquisas realizadas em cada país, espera-se colaborar em aspectos que possam contribuir significativamente à emergência de políticas públicas nacionais e sistemas de gestão municipais competentes, que sustentem os novos referenciais teóricos e críticos sobre a qualidade da educação da infância, tanto no Chile como no Brasil, e no restante do continente.

\subsection{Questões Iniciais}

A partir das indagações iniciais:

1) Pode a gestão municipal ser configurada como fator de qualidade da Educação Infantil?

2) Quais são as similaridades e as discrepâncias entre a configuração de políticas públicas de Educação Infantil estabelecidas pelo Brasil e pelo Chile - dois Estados com sistemas de gestão educativa diferentes - que podem repercutir na concepção da gestão municipal como fator de qualidade?

Os tópicos a seguir apresentarão objetivos geral e específicos a serem alcançados. 


\subsubsection{Objetivo Geral}

Descrever, explorar e comparar a configuração de políticas públicas de Educação Infantil formalizadas pelos Estados do Brasil e do Chile na sua relação com a gestão municipal, a partir dos princípios de descentralização da gestão educativa, qualidade da Educação Infantil e responsabilização educativa, a fim de compreender as tensões, implicações e possibilidades da gestão municipal como fator de qualidade da Educação Infantil.

\subsubsection{Objetivos Específicos}

Visando assegurar a coerência e a pertinência da pesquisa em torno do objetivo geral, elencase:

- Situar os países em estudo no panorama sul-americano em relação aos principais fatores sociais, políticos e econômicos que circunscreveram a configuração de políticas de Educação Infantil no continente até ser legitimada como interesse de governo.

- A partir da caracterização de três períodos históricos, desde o ano 1973 até 2014, descrever a configuração das principais políticas públicas de Educação Infantil formalizadas pelo Estado do Chile, na sua relação com a gestão municipal como eixo de qualidade.

- A partir da caracterização de três períodos históricos desde o ano 1964 até 2014, descrever a configuração das principais políticas públicas de Educação Infantil formalizadas pelo Estado do Brasil, na sua relação com a gestão municipal como eixo de qualidade.

- Reconhecer tensões, convergências e divergências da gestão educativa de Educação Infantil em ambos os países, a partir dos princípios de descentralização da gestão educativa, da qualidade da Educação Infantil e da responsabilização educativa.

- Comparar ambos os países para compreender as implicações, possibilidades e tendências que podem repercutir na concepção da gestão municipal como fator de qualidade no Brasil e no Chile. 


\subsection{Metodologia}

Considerando que a preocupação pela Educação Infantil se tornou um fenômeno transnacional, faz-se imprescindível estudá-la como estrutura organizacional, e como esta é influenciada pelas características sociais, econômicas, políticas e pedagógicas, locais e mundiais, até ser legitimada como interesse de governo. O questionamento e a interpretação resultantes deste exercício podem trazer importantes reforços para o entendimento das reformas educacionais próprias e alheias, assim como das escolhas passadas, presentes e futuras na educação dos contextos estudados. Com esta perspectiva, realizar-se-á um estudo comparado entre dois países latino-americanos: Brasil e Chile. Segundo Ferreira (2008, p. 124), “a comparação em educação gera uma dinâmica de raciocínio que obriga a identificar semelhanças e diferenças entre dois ou mais factos, fenómenos ou processos educativos e a interpretá-los levando em consideração a relação destes com o contexto social, político, económico, cultural, etc. a que pertencem".

Os primórdios modernistas da Educação Comparada (EC) como campo de estudo são convencionalmente ligados ao período do pós-Iluminismo, no início e em meados do século XIX, especificamente ao trabalho pioneiro de Marc-Antoine Jullien de Paris, intitulado Esquisse et vues préliminaires d'éducation comparée ${ }^{2}$, e aos discursos de formuladores de políticas educacionais, reformadores e administradores na área da educação na Europa e nos Estados Unidos (KALOYIANNAKI E KAZAMIAS, 2012). A Educação Comparada surgiu, assim, num contexto histórico em que a expansão escolar e a afirmação da ciência se constituíam como pilares fundamentais do progresso e como contribuição para reformas educativas mais fundamentadas.

A curiosidade por conhecer os sistemas educacionais de outros países teve grande impulso no século XX, motivada pelo esforço de "construção de sistemas nacionais (...) que retirassem o encargo da educação dos limites da responsabilidade de cada indivíduo (...) para passá-la para a responsabilidade do Estado" (GOERGEN, 1991, p. 6-7). Desde então, estudiosos procuraram conhecer outras experiências educacionais que pudessem inspirar os sistemas de seus países. Na América Latina, "coerente(s) com a lógica de dependência e subordinação (em relação) aos centros hegemônicos”, desde o início da constituição de seus sistemas educacionais, procuraram espelhar-se nos modelos praticados nos países desenvolvidos, tornando comuns os estudos que pretendiam comparar o "desenvolvimento

\footnotetext{
${ }^{2}$ Nota de tradução: "Esboço e opiniões da educação comparada".
} 
educacional em diferentes países" (IBIDEM, p. 8-9). É desta perspectiva que os estudos comparados tiveram grande impulso na segunda metade do século $\mathrm{XX}$, utilizados por "centros de pesquisa (...) e pelos organismos intergovernamentais para subsidiar políticas educacionais nos países periféricos" (KRAWCZYK e VIEIRA, 2003, p. 127-128). Organismos Internacionais prestigiados, como a UNESCO, o Conselho da Europa, a OCDE e o Banco Mundial, têm promovido sobretudo estudos comparativos em educação com base na recolha e no tratamento de dados quantitativos sobre os diferentes países, fornecendo importantes informações aos políticos e aos reformistas em geral e, dessa maneira, condicionar a Educação Comparada à dedução de "princípios" e "regras" capazes de tornar a educação uma "técnica" que justificasse os interesses pragmatistas e imediatistas das entidades que dirigem as políticas educativas e as reformas a serem adotadas por um país para colocá-lo no caminho do aperfeiçoamento e do progresso.

A insistência na apresentação de dados descritivos que deveriam favorecer a comparação com vistas a avaliar as melhores escolhas educativas para as transpor para outros países contrastou-se com as propostas de James E. Russel e Michael Sadler, o primeiro procurando uma abordagem em que a comparação dos sistemas educativos se fizesse sempre em estreita relação com as condições em que as sociedades se inseriam; e o segundo introduzindo a ideia de que cada sistema educativo não é facilmente separável da sociedade que lhe serve de base (FERREIRA, 2008, p.128) e que é necessário compreender os sistemas educativos de cada país e explicar as especificidades de cada um, levando em consideração o contexto social que os envolve.

Um sistema nacional de educação é algo vivo, produto de lutas e dificuldades
esquecidas e de batalhas do passado. Contém em si algo da dinâmica secreta da vida
nacional. Reflete, ao mesmo tempo que procura remediar, os defeitos do carácter
nacional. Instintivamente põe, com frequência especial, ênfase naqueles aspectos da
formação que o carácter nacional necessita. Da mesma forma evita acentuar tudo o
que no passado causou conflitos que podem dividir a vida nacional. Mas é provável
que, se captarmos com um espírito aberto e compreensivo as relações e os
significados profundos de um sistema educativo estrangeiro, nos vejamos melhor
preparados para nos introduzirmos no espírito e na tradição do nosso sistema [...] O
valor prático de estudar o funcionamento dos sistemas educativos estrangeiros, no
seu verdadeiro espírito e com precisão científica, é que, como resultado disso,
estaremos melhor preparados para estudar e compreender o nosso (SADLER, 1964,
p. 313-314).

A partir de Michael Sadler, a Educação Comparada tomou uma postura mais explicativa e analítica. Sem preocupar-se tanto com o que deve ser imitado ou transplantado do estrangeiro, o que pretende é compreender o sistema educativo do país através do estudo dos fatores e das forças que determinam e condicionam os sistemas educativos em geral. Nas 
décadas seguintes, outros estudiosos tentariam avançar nessa linha, vindo a explicar as semelhanças e as diferenças da educação dos diferentes países através de expressões como caráter nacional, cultura, raça, forças imanentes que, embora demonstrassem um esforço de conceitualização, vieram a ser consideradas prejudiciais à objetividade da abordagem comparativa, por correntes positivistas que se desenvolveram no período pós Segunda Guerra Mundial. A discussão acerca dos estudos comparados revela diversas vertentes de análise e tensões que ainda permanecem, relacionadas aos princípios, formas de intervenção e de abordagens dos fenômenos educativos que as pesquisas desse campo apresentam. Sem ter pretensão de discutir aqui a problemática presente nesse campo de pesquisa, serão salientados os pressupostos metodológicos utilizados para a realização do estudo comparado em pauta, sob os enfoques da perspectiva de Sadler e da abordagem específica de Barroso (2005), que afirma que um estudo das políticas educacionais deve tomar como base a compreensão sobre o processo histórico de regulação das políticas públicas e, portanto, os encaminhamentos metodológicos das análises nas atuais pesquisas comparativas devem apresentar alterações decorrentes da mudança no papel do Estado e nos mecanismos estruturais de sua gestão, processo esse que deve ser compreendido, segundo o autor, mediante três aspectos: a regulação transnacional, a regulação nacional e as microrregulações locais.

Assim, no desafio de comparar contextos nos quais se organizam e constroem concepções que consagram sentidos e definem limites, sem que isso gere categorização ou classificação, o estudo aqui proposto se associa ao esforço de descrição e compreensão das políticas de Educação Infantil efetivadas no Chile e no Brasil, na sua relação com a gestão municipal como fator de qualidade.

Pretende-se, inicialmente, descrever as mudanças realizadas nos sistemas educacionais, situando-as historicamente. Para isso, foi feita, em ambos os países, uma caracterização de três momentos históricos chaves na configuração de políticas públicas de Educação Infantil. Neste sentido, foi necessário responder a duas indagações fundamentais nos dois países estudados: 1. Quais são os principais movimentos dos Estados nacionais na configuração de políticas públicas de Educação Infantil? 2. Quais dessas mudanças foram efetivadas para dar sustentação às políticas de descentralização da gestão educativa, de melhoria da qualidade da Educação Infantil e de fortalecimento da responsabilização municipal?

Um segundo bloco de perguntas permitiu detalhar e analisar as repercussões das reformas educacionais de cada contexto: 1. A que níveis de governo e em que momento foi descentralizada a Educação Infantil? 2. Qual é a importância conferida pelos Estados 
nacionais à responsabilização da gestão municipal como fator de qualidade da Educação Infantil? 3. Quais foram as concepções de qualidade da Educação Infantil que predominaram nos períodos históricos estudados? 4. A configuração de políticas públicas favoreceu à gestão municipal como forma de redução das desigualdades e aumento do respeito dos direitos das crianças?

As respostas a essas perguntas foram encontradas na revisão bibliográfica e nas legislações do Chile e do Brasil, de maneira a entender, com mais propriedade, a amplitude e o significado que essas políticas tiveram para os sistemas educacionais nacionais e suas concepções de Educação Infantil. Destarte, foi realizado um levantamento documental em cada país de: 1. A Constituição Política; 2. As principais políticas públicas sobre financiamento, organização institucional, currículo e formação docente da Educação Infantil; 3. Pesquisas nacionais e académicas sobre o contexto das políticas públicas de Educação Infantil, na sua relação com os modelos de descentralização educativa, qualidade e responsabilização municipal adotados.

Paralelamente, foram pesquisados e sistematizados um conjunto de dados estatísticos de Educação Infantil que contribuíram para uma visão mais completa de cada cenário. $\mathrm{O}$ Ministério de Educação (MINEDUC) e o Ministério de Planificação (MIDEPLAN) do Chile disponibilizam, todos os anos, desde 1998, um compêndio de estatísticas educacionais, com dados sobre matrículas, gastos educacionais e indicadores diversos, todos facilmente dispostos nos portais dos referidos ministérios. No Brasil, as estatísticas educacionais foram mais difíceis de sistematizar pela variedade de fontes, por isto, além do Ministério de Educação (MEC), foi necessário apurar as informações do Instituto Brasileiro de Geografia e Estatística (IBGE) e do Instituto Nacional de Estudos e Pesquisas Educacionais Anísio Teixeira (INEP). Porém, em ambos os contextos, as dificuldades se centraram na falta de informações do início e de antes da década de 1990, e na impossibilidade de categorizar os dados da mesma maneira em ambos os países para a comparação.

Aliás, algumas pesquisas e artigos acadêmicos de vários autores chilenos e brasileiros foram essenciais para esclarecer o contexto de cada país. Do lado da cordilheira, os estudos de Andrea Tokman e Maria Victoria Peralta sobre o percurso da Educação Infantil chilena; de Rodrigo Cornejo e Maria Angélica Oliva sobre descentralização e municipalização da Educação no Chile; e de Alejandra Falabella sobre responsabilização municipal em educação, disponibilizaram uma fonte rica de informações que complementaram os antecedentes da pesquisadora e contribuíram para uma melhor descrição e análise. Da mesma forma, no Brasil, sendo o contexto menos explorado, artigos de pesquisadoras como Fúlvia Rosemberg 
e Bianca Correa, sobre as tensões da Educação Infantil brasileira; Maria Malta Campos, sobre políticas públicas e gestão de Educação Infantil; Lisete Arelaro, sobre financiamento e descentralização educativa; Maria Cármen Barbosa e Bruna Ribeiro, sobre avaliação de Educação Infantil nos contextos municipais, foram muito significativos para elucidar os caminhos de Educação Infantil, políticas públicas, organização do Estado nacional e descentralização no Brasil.

É importante destacar, como informação complementar, o texto de Theresa Adrião (2009) intitulado Educação no Chile: Olhares do Brasil; o estudo de Juca Gil (2000) intitulado $O$ mito da descentralização do ensino: o caso chileno; e a pesquisa Estudio de Calidad Educativa en Educación Parvularia: Experiencias Internacionales y Representaciones Sociales Nacionales (2015), realizada pela Universidade Alberto Hurtado, do Chile. Esse referencial representa o interesse concreto de aproximação e conhecimento entre o Chile e o Brasil, especialmente nos temas educacionais.

O objetivo final deste trabalho, como dito, envolve comparar a configuração de políticas públicas de Educação Infantil formalizadas pelo Estado do Brasil e do Chile na sua relação com a gestão municipal como eixo de qualidade. Os aspectos que aproximam e distanciam os países estudados são procurados na influência que os princípios de descentralização da gestão educativa, qualidade da Educação Infantil e responsabilização municipal têm sobre as possibilidades e as implicações da gestão local, como fator de qualidade da Educação Infantil. A comparação, como no entendimento de Zemelman (2003, p. 88-89)

(...) Tem que ser capaz de reconhecer as potencialidades do contexto. Não se trata apenas de ajustar contextos históricos e sociais às exigências normativas de um modelo, por mais fundamento teórico que o modelo tenha, se previamente não se fizer o esforço de se perguntar a que potencialidades do contexto corresponde aquele modelo (Tradução minha).

Só assim é possível percorrer algumas trilhas que ajudem a compreender as mudanças educacionais efetivadas nesses dois países, identificando, mesmo em suas similitudes, diferenciações próprias das identidades nacionais que as influenciaram e, em suas diferenciações, motivações dos valores nacionais que as adotaram. 


\subsection{Conceitos relevantes}

Ao aproximarmo-nos do desenvolvimento dos objetivos do estudo, é importante salientar alguns conceitos que subsidiarão a análise central da pesquisa e facilitarão seu entendimento. As opções conceituais iniciais do presente estudo relacionam-se, essencialmente, com o amplo processo de mudanças nas políticas públicas efetivadas no Chile e no Brasil nas últimas décadas em torno da Educação Infantil, em especial desde 1990, as quais receberam em grande parte dos casos a denominação genérica de reformas. No trabalho, foram enquadradas muitas das políticas de mudanças realizadas pelos Estados nacionais de ambos os países. A qualificação de "reformas" dadas a essas mudanças se presta a lhes conferir legitimidade, pois, como assinala Borón (1999, p. 11), reforma é um conceito originário de uma "concepção iluminista ligada a transformações sociais e econômicas orientadas para uma sociedade mais igualitária, democrática e humana”. No mesmo sentido, Oliveira (1996, p. 94) afirma que reformas, originariamente, eram a representação de "um avanço democrático conjugado a um avanço em um contexto popular", embora atualmente, na prática, a história nos indique que a maioria das reformas de nossa sociedade ocidental tem sido, nas palavras de Borón, "orientadas para aumentar a desigualdade econômica e social e para esvaziar de todo conteúdo as instituições democráticas” (BORÓN, 1999).

A partir dessa referência, ganham também relevância os conceitos de políticas públicas, políticas educacionais, políticas sociais e Educação Infantil.

Políticas públicas são entendidas como um conjunto de medidas e decisões que dirigem ações de governo. Assim, o estudo parte da compreensão de que a política educacional integra uma "totalidade maior" e, por isso, deve ser considerada

\footnotetext{
(...) em sua articulação com o planejamento mais global que a sociedade constrói como seu projeto e que se realiza por meio da ação do Estado. São, pois, as políticas públicas que dão visibilidade e materialidade ao Estado e por isto, são definidas como sendo o "Estado em ação" (AZEVEDO, 2001, p. 60).
}

Portanto, compete ao Estado nacional e às suas esferas subnacionais de governo, a criação e a implementação de políticas educacionais vinculadas ao projeto de sociedade que se pretende implantar e ao perfil de cidadão que quer se formar, projeto que "é influenciado por todos os setores da sociedade com poder para manifestar seus interesses junto ao governo, na ordem direta de suas diferentes capacidades de pressão" (Ibidem, p. 60).

Ora, num continente como o nosso, em que predominam as desigualdades, fruto do processo histórico-político-sócio-econômico e que se refletem perversamente no sistema 
educativo, faz-se necessária a construção e a implementação de políticas sociais por parte dos Estados, com o objetivo de minimizar o fantasma das desigualdades e equalizar as oportunidades. Demo (1994, p.14) afirma:

Política social pode ser contextuada, de partida, do ponto de vista do Estado, como proposta planejada de enfrentamento das desigualdades sociais. Por trás da política social existe a questão social, definida desde sempre como a busca de composição pelo menos tolerável entre alguns privilegiados que controlam a ordem vigente, e a maioria marginalizada que a sustenta.

Neste cenário, a educação tem sido configurada, em grande parte da América Latina como uma importante ação social do Estado, com respeito tanto à promoção social quanto ao combate da pobreza. De acordo com Campos (2003, p.186-188), as políticas educacionais sofreram alterações nas suas orientações, tendendo a responder às demandas crescentes de maior integração social das populações vulneráveis, associadas ao "direito universal à educação", sendo parte do padrão de proteção social vigente. Isso implicou em que algumas políticas sociais fossem absorvidas pelo sistema educacional, enquanto que outras tenham sido focalizadas exclusivamente nos segmentos mais pobres e como parte de políticas assistenciais. $\mathrm{Na}$ intersecção, muitas vezes contraditória, entre as políticas assistenciais voltadas para os segmentos mais pobres e as políticas educacionais - por definição, universalistas e abertas a todos -, há uma convivência marcada por estratégias políticas e econômicas de organismos internacionais que influenciaram os movimentos de estruturação do Estado, desregulamento da gestão e a priorização de ações básicas de saúde, nutrição e programas de caráter produtivo, como o investimento na formação de força de trabalho apta, também chamado "capital humano" (OLIVEIRA E DUARTE, 2005, p.289).

A Educação Infantil (que, a partir deste momento do trabalho, será nomeada também como EI) é o ponto crucial neste tema, pois ela foi concebida por muito tempo como um subsetor de políticas educacionais e de assistência ao(à) trabalhador(a), sendo integrada às políticas sociais. De fato, grande parte das transformações ocorridas no início da educação de crianças de zero a cinco anos na América do Sul foram resultantes das necessidades de priorizar a qualidade da assistência e do cuidado às crianças enquanto seus pais trabalhavam, além de garantir a intervenção do poder público "no sentido de ordenamento hierárquico de opções entre necessidades e interesses explicitados pelos diferentes segmentos que compõem a sociedade" (ROSEMBERG, 2002, p.29). Atualmente, reconhece-se o Estado como principal provedor de EI pública, assim como o responsável pela maioria das mudanças e reformulações nas políticas educacionais e sociais dessa etapa. Porém, as diferentes 
concepções legitimadas historicamente, que transitam da consideração da criança como receptor de medidas assistenciais e de cuidado até ser reconhecida sujeito de direito à educação e ao desenvolvimento integral têm sido fortemente atingidas por processos mais amplos de reorganização do Estado nacional e do sistema educativo, repercussão da economia global, descentralização da gestão, e por marcadas influências tanto de setores da sociedade quanto de organizações internacionais, estas últimas com permanente participação e poder nas reformulações da educação de infância de qualidade através do tempo (ROSEMBERG, 2002). Torna-se, ainda, necessário enfatizar que esses processos não são homogêneos e respondem a construções próprias de cada sociedade, sem estar isentas de tensões, conflitos, coalizões e negociações. Daí o interesse por aprofundar o contexto específico do Brasil e do Chile, para compreender os fundamentos que sustentam as concepções de Educação Infantil de qualidade e sua coerência com os sistemas de gestão nacional e local. Assim, diante da impossibilidade de definir a Educação Infantil como conceito único, será entendida nesta pesquisa como a educação destinada a crianças menores de 6 anos e fruto de processos políticos, econômicos, sociais e históricos de cada contexto, que ganha diferentes contornos e especificidades ao longo do tempo.

Finalmente, consideram-se relevantes, como base conceitual, os conceitos de Estado Unitário e Estado Federativo, por acreditar que a configuração das políticas públicas depende, em grande parte, das diferentes formas de governo assumidas pelos países de América do Sul, particularmente no Chile e no Brasil.

Nos Estados Unitários, em tese, os governos locais dispõem de menos autonomia do que nos Estados Federativos, pois

\begin{abstract}
Apenas o governo central tem autoridade política própria, derivada do voto popular direto. A unidade do Estado Nacional está garantida pela concentração de autoridade política, fiscal e militar no governo central, ao passo que a autoridade política dos governos locais é derivada de uma delegação de autoridade da autoridade política central (ARRETCHE, 2002, p. 28).
\end{abstract}

Abrucio (2003, p. 230) identifica que o que diferencia o Estado Unitário é que a “soberania está concentrada no governo central e é, por tal motivo, única e indivisível". Ainda corrobora da afirmação de Arretche quando diz que "o poder dos entes subnacionais deriva da ação voluntária da esfera nacional, que delega funções e graus de autoridade". Nesse sentido, a distribuição do poder entre o governo central e as unidades subnacionais é hierárquica e assimétrica. 
Os Estados Federativos, por sua parte, resultam de um pacto entre as unidades territoriais que escolheram estabelecer uma parceria, conformando uma nação. Portanto, "há uma união voluntária entre os cidadãos dos territórios constituintes, que mantêm seus direitos originários, mas cujo produto é a constituição de um governo nacional autônomo" (Ibidem, p. 232). Essa autonomia está ligada ao princípio de “equidade”, tanto na relação entre os indivíduos como entre várias regiões federadas:

Esse valor/objetivo capaz de legitimar solidariamente a convivência federativa supõe a existência de instrumentos e mecanismos comuns aceitos e capazes de compensar, de maneira imediata, os desequilíbrios agudos e inesperados, mas também capazes de promover uma progressiva diminuição das desigualdades mais permanentes ou estruturais (FIORI, 1995a, p. 25).

Assim, a conformação dos Estados Federais precisa levar em conta as relações entre o Governo Central e os Estados-Membros, e estes com as "menores unidades de governo": os municípios. Dessa perspectiva, ganha importância a divisão de responsabilidades ou de competências entre os diversos governos que constituem os Estados Federais, os quais tem competências próprias, havendo algumas que são exclusivas de cada governo e outras que são exercidas em comum por mais de um governo.

Os conceitos relacionados e tratados ao longo deste capítulo ganharão maior significado no desenvolvimento do estudo, a partir da análise do contexto e das mudanças educacionais nos países estudados, e, de forma preponderante, a partir dos princípios de descentralização da gestão, qualidade de Educação Infantil e responsabilização municipal, que serão tratados amplamente mais adiante, como parte do exercício de comparação entre as realidades chilena e brasileira.

\subsection{Encaminhamentos Estruturais}

Este texto foi elaborado em três partes principais.

$\mathrm{Na}$ primeira parte, foram apresentadas a introdução e metodologia adotada para a concretização do estudo. Além de identificar as principais indagações que motivam a pesquisa, são resumidas as etapas de descrição e exploração, bem como alguns caminhos percorridos para analisar as políticas dos dois países estudados. Também, neste capítulo, foram apresentados os conceitos considerados relevantes para o início do desenvolvimento do estudo e aqueles utilizados para mediar a comparação a se realizar. 
Na sequência, o segundo capítulo, "A configuração das políticas de Educação Infantil no Chile e no Brasil: contexto sul-americano, marcos legais, percursos e entraves", situa os países em estudo no panorama sul-americano em relação aos principais fatores sociais, políticos e econômicos que circunscreveram a configuração de políticas de Educação Infantil no continente. A partir da caracterização de três períodos históricos em cada país, realiza-se uma descrição sobre a trajetória das principais políticas públicas do Chile e do Brasil em separado, apresentando o contexto em que foram geradas para extrair as principais tensões do sistema de gestão educativa nacional na sua relação com a gestão municipal, além de elucidar o percurso do papel da gestão local do município como fator de qualidade da Educação Infantil.

No terceiro capítulo, intitulado "Educação infantil no Chile e no Brasil, em busca de qualidade: linhas de teorização”, identificam-se as convergências e as divergências entre o Chile e o Brasil, a partir de uma comparação baseada em três linhas de teorização referentes aos mecanismos de descentralização da gestão educativa adotados por cada país, aos princípios de qualidade da Educação Infantil e aos modelos de responsabilização educativa.

Por fim, nas considerações finais, estabelecem-se as principais conclusões desta pesquisa. 


\section{A CONFIGURAÇÃo dAS POLÍTICAS DE EDUCAÇÃO INFANTIL NO CHILE E NO BRASIL: CONTEXTO SUL-AMERICANO, MARCOS LEGAIS, PERCURSOS E ENTRAVES}

A infância e as crianças têm experimentado, desde as últimas décadas do século XX, uma nova visibilidade, e sua educação tem se convertido, cada vez mais, em objeto de atenção. A educação de crianças pequenas em estabelecimentos educacionais integrantes do sistema de ensino, tal como hoje a conhecemos, tem sido parte de uma construção histórica para a qual contribuíram incontáveis pensadores, educadores e pesquisadores de vários campos do conhecimento, tanto da psicologia do desenvolvimento, da biologia, da medicina, da pedagogia, da sociologia e da neurociência, quanto estadistas, políticos, economistas e dirigentes de organizações governamentais e não governamentais.

Assim, num exame sobre o desenvolvimento da Educação Infantil em diferentes países da América do Sul, através de documentos produzidos por organismos internacionais que têm dedicado uma farta produção a essa área, permitem explanar que, a partir dos anos 1990, emerge um interesse renovado pela educação das crianças de 0 a 6 anos, observando-se uma expressiva ampliação na oferta e na obrigatoriedade dessa etapa educativa.

Diversos autores, entre eles Borón (1999) e Gentili (2002), ao estudarem as reformas educacionais contemporâneas, chamam atenção à similitude dos processos de implementação entre países e regiões. Destacam a presença de um tipo de "concertação" ou "agenda partilhada", mediada por organismos internacionais, como Banco Mundial (BM), UNESCO, UNICEF, que indicam regulações transnacionais, metas e ações que, ao longo das últimas décadas, vêm reconfigurando os sistemas educacionais, de modo que estes possam, com mais eficácia, atender as novas demandas da sociedade e do capitalismo contemporâneo. No caso da EI, esse fenômeno adquire lógica ao se constatar a adesão dos governos da região a compromissos firmados em instâncias mundiais em "nome" da infância, cujos princípios têm produzido desdobramentos nas políticas nacionais além de estarem presentes na elaboração, na implementação e na execução de planos ou programas educacionais orientadores das reformas.

Porém, a compreensão das relações entre os Estados nacionais e essas forças "supranacionais", também chamadas "forças globalmente estruturadas" (DALE, 2004, p.454), requer entender que não se trata apenas de processos lineares, mas, ao contrário, para bem compreendermos essa relação global/nacional, é preciso acreditar que as construções e as orientações adotadas pelos países resultam de complexas interações entre os modos locais de 
formulação e interpretação dos princípios internacionais, bem como da articulação, por parte do Estado, dos recursos históricos, econômicos, estruturais e políticos como possibilidade de resposta às demandas da sociedade.

Considerando então esse último aspecto como central no estudo da configuração de políticas de Educação Infantil no Chile e no Brasil, este capítulo está dividido em três partes que, articuladas, permitem obter a descrição do panorama sul-americano e dos dois países em separado, de acordo com o recorte temporal e os objetivos do estudo, para facilitar, assim, a análise e a comparação nos capítulos posteriores.

\subsection{O ajuste estrutural e a EI como superação da pobreza da América do Sul}

Na América do Sul, a origem da EI é próximo, relacionada ao tempo e aos modelos de instituição. No caso do Chile e do Brasil, a preocupação pela educação da pequena infância surgiu no início do século XX, com fortes influências pedagógicas norte-americanas e europeias, principalmente da escola fröbeliana, que estabelece os kindergardens como centros exclusivos de educação para crianças desde os 4 anos. Embora em ambos os países tenha havido a intenção de ampliar esse estilo de educação como parte de iniciativas públicas ${ }^{3}$, houve muita controvérsia na época acerca da necessidade e da importância dessa forma de atendimento educacional no sistema público que, somado a oscilações econômicas e políticas de cada contexto, prejudicaram sua valorização e expansão na esfera pública, restringindo a oferta majoritariamente ao setor particular. Em relação à pequena infância, a educação pública de crianças de 0 a 4 anos não foi tema relevante das agendas de governo, nem foi centro de pesquisas acadêmicas nas primeiras décadas do século XX, pois era considerada uma ação que devia ser realizada exclusivamente dentro do contexto privado familiar. Porém, a crescente urbanização registrada na época, consequência da industrialização e do êxodo rural, foi um fenômeno produzido no Chile e no Brasil, que empobreceu as condições de vida do trabalhador, incrementou a necessidade da incorporação da mulher ao trabalho e reformulou processos sociais, econômicos e políticos em cada país, que exigiram medidas do Estado para garantir a proteção dos trabalhadores e de suas famílias (OLIVA, 2008 \& ROSEMBERG, 2002). Foram os sindicatos e os movimentos sociais de trabalhadores da época que exigiram,

\footnotetext{
${ }^{3}$ No Brasil, o primeiro Jardim de Infância público foi instalado anexo à Escola Caetano de Campos, em São Paulo, em 1896 (KISHIMOTO, 1988) e, no Chile, o primeiro Kindergarten da Escuela Normal N 1 de Santiago, em 1906 (PERALTA, 2010).
} 
dos respectivos Estados, a criação de lugares específicos para oferecer atendimento às crianças enquanto seus pais trabalhavam fora de casa, ações que, em conjunto, foram consolidadas como parte dos sistemas de proteção social.

Neste sentido, e de acordo com pesquisa realizada pelo Ministério de Educação do Brasil (MEC) em parceria com a UNESCO, intitulada A Educação Infantil nos países do MERCOSUL: Análise Comparativa da Legislação (2013), os caminhos da construção da EI pública para crianças menores de seis anos nos países membros do tratado ${ }^{4}$ estão diretamente ligados a acontecimentos históricos, de organização social mais ampla, do que ao estritamente pedagógico. Daí que o surgimento e a legitimação do atendimento às crianças por quase todo o século "apresentou uma tríplice semelhança: a) a bifurcação de caminhos entre assistência e educação; b) a precedência temporal do modelo assistencial; e c) a renda familiar ou classe social como fator determinante para a criança seguir um ou outro caminho" (2013, p. 16). Estas três semelhanças explicitam o caráter da EI na época marcado pela diferenciação de classe: enquanto que o atendimento dos filhos das mulheres trabalhadoras que começaram a ingressar nas fábricas se realizava em locais - creches no Brasil e salas cunas no Chile - que priorizaram a beneficência e as medidas assistenciais orientadas à sobrevivência, à alimentação, à saúde e ao cuidado, principalmente devido às condições vulneráveis em que viviam as crianças afetadas pela pobreza das suas famílias; as crianças de famílias mais abastadas, assistiam a instituições - jardins de infância no Brasil e jardines infantiles no Chile -, que ao contrário, tinham um explícito propósito educacional (Ibidem, p.18).

Nessa mesma linha, Chamboredon e Prevot (1986, p.37) afirmam que a diferenciação do atendimento da EI pode ser explicada, por um lado, por meio de fatores derivados da categorização das classes sociais - como trabalho feminino, urbanização, número de filhos, recursos econômicos, etc - e, por outro, através de fatores culturais relacionados à definição da primeira infầncia como "objeto pedagógico" e como período de aprendizagem. A "descoberta" das potencialidades da criança como futuro aprendiz e, sobretudo, a crença da importância desse tempo como base para a constituição da personalidade e das potencialidades cognitivas como pré-requisito para o sucesso escolar foram definindo o status da criança como sujeito educável, sustentado principalmente por teorias vindas da área da psicologia do desenvolvimento. Dessa maneira, embora na América do Sul a diferenciação da

\footnotetext{
${ }^{4}$ O MERCOSUL (Mercado Común do Sul) é um tratado de integração comercial entre países de América do Sul, formado pelos Estados Partes: Argentina, Brasil, Paraguai, Uruguai, Venezuela e Bolívia - este último em estado de adesão - e pelos Estados Associados: Chile, Colômbia, Equador, Peru, Guyana e Suriname. A pesquisa referida considera o estudo da Educação Infantil de Argentina, Brasil, Paraguai e Uruguai, com a participação do Chile como convidado.
} 
EI tenha condicionado por muito tempo as funções das instituições e sua valorização na sociedade, com o passar do tempo, a história parece tender à aproximação entre os dois caminhos, constituindo-se, em alguns países, como interesse e objetivo de governo: a educação e o cuidado, na primeira infância, a partir do seu nascimento, como direito universal da criança e dever do Estado.

Como é que esse complexo processo de integração entre assistência e educação tem se dado em alguns países do continente? Para responder tal questão, é preciso revisar alguns antecedentes históricos.

Entre os anos de 1960 a 1980, verifica-se uma época especialmente agitada para o continente sul-americano. Brasil, Chile, Argentina, Uruguai, Bolívia, Paraguai e Equador enfrentaram governos ditatoriais, impostos no contexto da Guerra Fria e de um mundo bipolar ${ }^{5}$; regimes fortemente centralizados que permitiram o controle burocrático-autoritário das políticas sociais e levaram grande parte dos países do continente a adotarem políticas respaldadas no modelo americano de educação. As transformações e a decorrente crise econômica durante os anos 1970 levaram os governos latino-americanos a efetivarem uma série de ajustes estruturais não apenas nas suas economias, mas também na organização da sua sociedade e, inclusive, no caráter que assumiram os Estados nacionais.

Segundo Soares (1996, p.21-22), a crise capitalista só ganha dramaticidade na América do Sul após o final da década de 1970, “com a restrição dos créditos privados para os países do continente e conferindo ao sistema financeiro enorme poder de direcionamento das políticas assumidas pelos governos latinos". Os países endividados, limitados em sua possibilidade de captar créditos com bancos privados, dependeram do Banco Mundial e do Fundo Monetário Internacional para obter novos financiamentos, o que provocou a legitimidade e o poder desses organismos multilaterais como promotores das novas políticas de desenvolvimento e de gestão do Estado, as quais foram adotadas pelos países capitalistas em geral, mas especialmente pelos países subdesenvolvidos. A obtenção de novos créditos pelos governos passou a depender da concordância com uma série de condicionalidades impostas por essas agências, um renovado status para interferir "diretamente na formulação da política interna e influenciar a própria legislação dos países” (Ibidem, p.24). Essa situação colocou em xeque o papel dos Estados nacionais latino-americanos, que passaram a ter questionada suas competências no plano econômico, assim como sua capacidade de efetivar

\footnotetext{
${ }^{5}$ Uma referência à disputa entre os dois principais eixos políticos de então: de um lado, o Mundo Capitalista, liderado pelos EUA e, de outro, o Mundo Socialista, liderado pela URSS.
} 
políticas sociais.

O "remédio" único capaz de solucionar a crise veio de um ideário neoliberal imposto também por organismos multinacionais e bancos privados após os anos $1980^{6}$, instituições que partilhavam a ideia de que a intervenção do Estado na economia era a principal causa da crise de acumulação do capital, e também “de que o mercado é a única instituição capaz de coordenar racionalmente quaisquer problemas sociais, sejam eles de natureza puramente econômica ou política" (TEIXEIRA, 1996, p.195). Sobre os resultados do nomeado "ajuste neoliberal", chama a atenção que, mesmo sendo relativamente sucedido no que concerne à contenção da crise inflacionária no que se refere às taxas de crescimento dos países, os resultados foram mínimos. Da mesma maneira, com respeito aos resultados sociais, a "onda" neoliberal foi absolutamente nefasta, a ponto de ser definida por Borón como "holocausto social", o que não deixa de ser paradoxal, visto que as demandas civis se multiplicavam e a quantidade de pessoas em situação de pobreza e indigência aumentava, afetando milhões de crianças por ano. Foi configurado um novo papel para o Estado, no qual os direitos sociais e a obrigação da sociedade em garanti-los por meio da ação estatal eram desconsiderados. Ao contrário, emerge um estilo de Estado que só deve intervir quando existir a necessidade de aliviar a pobreza absoluta e de produzir aqueles serviços que o setor privado não pode ou não quer fazer, constituindo assim um Estado compensatório. De acordo com Araújo (2005), é decorrente dessa nova configuração que o conceito de equidade assuma importância, ou seja, um Estado que reduz as desigualdades, que assegura um patamar mínimo de condições sociais, mas que não persegue mais os princípios da universalidade e da igualdade.

A redução do protagonismo do Estado no que concerne ao gasto público social foi parte importante do processo de ajuste neoliberal, na medida em que a implementação de práticas de gestão da esfera pública fosse baseada na descentralização de responsabilidades e ações, o que tornou possível não apenas a privatização de programas sociais como também a transferência de responsabilidade para a própria população, pela oferta de serviços sociais. Esse processo teve grande êxito na América Latina, já fragilizada e fragmentada pelas ditaduras militares e pela fraca transição que as sucederam na década de 1980 (BORÓN, 2007; GENTILI, 2002).

Assim, as ações empregadas no combate à pobreza, em especial após a década de 1990, podem ser caracterizadas como um conjunto de medidas compensatórias e focalizadas,

\footnotetext{
${ }^{6}$ Cabe destacar que o Chile foi um dos primeiros países do continente a implementar políticas neoliberais impostas pelo BM, na metade da década dos anos 1970, no contexto da ditadura que afetou o país entre os anos 1973 e 1989.
} 
que buscam retirar da condição de miséria aqueles que não conseguem atingir o nível mínimo da sobrevivência, muito diferentes das políticas sociais de cunho universalistas que buscam a promoção dos direitos básicos da cidadania (ZICCARDI, 2001). Dentre essas ações, a educação se tornou foco privilegiado, sendo considerada como fundamental no rompimento dos ciclos de pobreza e na consolidação da equidade social. A partir dessa premissa, a Educação Infantil ganhou relevância, uma vez que poderia atuar nos setores historicamente desfavorecidos, como uma estratégia modificadora da situação de carência crítica.

Difundiu-se, então, no continente, a ideia da "mudança social via educação", postulando a Educação Infantil com o papel de compensar as carências culturais das crianças pobres, a importância da expansão institucional e a criação de condições de acesso equitativo às oportunidades educativas. Desse modo, as instituições de Educação Infantil, por criarem condições para o futuro sucesso escolar, serviriam de ponte para atravessar as diferenças existentes entre as classes sociais (KRAMER, 1995).

Segundo Rosemberg (2002), este período foi caracterizado também pela participação constante de organizações internacionais, como UNESCO e UNICEF, no âmbito da Educação Infantil. Sua inserção na América Latina implicou não apenas incentivos e políticas de indução à expansão do atendimento educacional via instituições não formais, ONGs ou aquelas nomeadas como "terceiro setor", senão também mudanças no tipo e nos modos de organização das instituições e suas práticas educativas para as crianças pequenas. Ainda assim, em termos de políticas públicas, a ampliação do atendimento ficou mais relacionada às políticas de assistência do que às políticas educativas, caracterizando-se pela prevalência de atendimentos organizados com baixo custo, da transferência de responsabilidades para outras esferas de ação e pela falta de financiamento suficiente, obstáculos que repercutiram no modelo de garantia de "educação de qualidade" em grande parte do continente. 


\subsubsection{O direito das crianças à Educação}

Concomitante ao intuito de ampliação da EI das ultimas décadas do século XX, movimentos sociais reivindicatórios e pesquisas da área na região avançavam no debate e na exigência acerca da concepção da Educação Infantil como direito das crianças, trazendo à tona a importância de repensar a educação das crianças pequenas em espaços coletivos a partir de um conjunto de conhecimentos que propiciaram a ruptura da concepção de Educação Infantil preparatória à escolarização obrigatória ou compensatória das carências culturais.

Especial participação no Brasil, desde a década de 1970, teve o movimento feminista, que considerava as demandas da Educação Infantil desde uma dupla perspectiva: a dos direitos das mulheres e a dos direitos das crianças. No Chile, o tema central foi a violação aos direitos humanos sofrida por crianças na ditadura, o que fez com que várias organizações lideradas por mulheres chefes de família - muitas delas viúvas de detidos desaparecidos tornassem os direitos da criança uma luta política, denunciando as situações de violência e demandando ao Estado medidas de proteção às crianças sem família como consequência da repressão exercida sobre seus pais.

Outra importante influência sobre a Educação Infantil da América do Sul, na época, foram as obras de Paulo Freire e Emília Ferreiro. Enquanto os livros de Freire se espalhavam nos países do continente que retomavam a democracia, os estudiosos colocavam ênfase na sua pedagogia, que concebia a educação como um processo de retroalimentação, no qual o professor e o aluno descobrem e aprendem através do diálogo e da escuta. As teorias de Ferreiro, por sua vez, puseram em questão os métodos preparatórios tradicionais de alfabetização das crianças, demonstrando que estas têm um papel ativo no aprendizado e são construtoras do próprio conhecimento.

Tais óticas também tiveram destaque nos acordos internacionais: a Convenção dos Direitos das Crianças (CDC) - ratificada em 1990, por 179 países, entre eles todos os da América do Sul - surgiu no auge dos movimentos em prol das crianças, generalizando uma sensibilidade relativa, em especial, no que concerne aos chamados direitos de proteção e aos direitos de provisão ou bem-estar. De acordo com Wintersberger (2006), na CDC, pela primeira vez as crianças foram reconhecidas como sujeitos legais, o que implicou questionar de modo fundamental a ordem geracional existente nas sociedades e países. Diferente das declarações anteriores, nas quais as crianças figuravam como "objetos de proteção", na Convenção elas foram consideradas sujeitos de direitos, não apenas abordando seus problemas como se não que lhes outorgando maior visibilidade. 
Sem pretender desconsiderar a importância da CDC como uma das primeiras agendas mundiais partilhadas pelos Estados em favor da infância, vários autores, entre eles o referido Wintersberger (2006) e Gaitán Muñoz (2006), assinalam que, assim como a Convenção possui méritos, possui também limitações, manifestadas, por exemplo, na redação, que se apresenta bastante diplomática, deixando brechas para diferentes interpretações, o que, às vezes, contradiz sua própria essência. De acordo com os autores, a concepção de "bem-estar" da infância e sua associação às políticas sociais relaciona-se diretamente com os modos de organização que o Estado assumiu em diferentes países, influenciando, em consequência, o próprio bem-estar das crianças, bem como a compreensão de seus direitos. Assim, seguindo essa análise, embora a Convenção reconheça o direito das crianças à educação, não menciona nem cria dispositivos legais que garantam o seu provimento obrigatório, exceto quando se trata do ensino primário, denominação que também é subjetiva e que pode variar significativamente nos diferentes países. De fato, no que se refere à educação proclamada na Convenção, ao se referir apenas ao "ensino primário", deixa de abordar o direito das crianças menores de 6 anos à educação. Dessa maneira, parece que a concepção de EI no documento continuou se circunscrevendo à perspectiva de proteção e de responsabilidade das famílias, as quais, conforme discutido anteriormente, podem receber auxílio do Estado em conformidade com as suas necessidades, carências e as políticas sociais estatais instauradas. É interessante perceber que essa relação família - Estado, na qual a família é protagonista, é também enfatizada no "modelo neoliberal", que define família como a grande responsável pelos seus membros, convertendo-se na chave para a retração das políticas públicas, assim como na ferramenta para a aquisição dos serviços de mercado (GAITÁN MUÑOZ, 2006), afastando-se do que concerne aos direitos das crianças propriamente ditas.

No ano seguinte à ratificação da Convenção, foi realizada a Cúpula Mundial pela Infância - com mais de 80 países signatários, entre eles o Chile e o Brasil - que gerou o documento Declaração Mundial sobre a Sobrevivência, a Proteção e o Desenvolvimento da Criança. Rosânia Campos (2008) analisa este entre outros documentos produzidos internacionalmente e assinados por países da América Latina. O plano de ação originário da Cúpula, afirma a autora, está focado em garantir as necessidades básicas de sobrevivência das crianças, sendo a educação mencionada de forma geral em apenas um dos vinte e cinco itens e afirmada como oportunidade para garantir uma vida produtiva.

Os países têm que trabalhar por programas de redução do analfabetismo que garantam oportunidades educacionais para todas as crianças, independentemente de sua origem e sexo; que preparem a criança para o trabalho produtivo e para as oportunidades de aprendizagem para toda a vida, isto é, pela educação 
profissionalizante, e que permitam que a criança cresça até a idade adulta num contexto cultural e social propício e protetor (ONU, 1989 - tradução minha).

Embora, da mesma forma como aconteceu com a CDC, não seja feita uma referência específica à EI como etapa educativa, ambas as convenções trazem concepções que orientarão posteriormente os debates e as políticas na região. Campos destaca três concepções claras: a) a educação da criança pequena deve ser responsabilidade da família, cabendo ao Estado a complementação desse processo, de acordo com as necessidades sociais das mesmas; b) a educação deve ser voltada para a formação produtiva, preparando o indivíduo para aprendizagens para a vida; e c) a definição da educação como oportunidade, deslocando-se, assim, do seu sentido histórico de direito (Campos, R. 2008, p. 63).

Os sucessivos encontros mundiais realizados na área trabalharam sobre as ideias básicas descritas no parágrafo anterior. A Conferência Mundial de Educação Para Todos (1990) e o Fórum Mundial de Educação para Todos (2000) estipulam a importância da integração da EI como primeira etapa da educação básica e a necessidade de um "planejamento polifônico" com a tarefa de divulgar a importância de educar as crianças durante os anos pré-escolares através de programas de proteção e desenvolvimento da primeira infância. Essas indicações podem ser organizadas em dois grandes conjuntos: indicações para atendimento às crianças maiores de 4 anos (pré-escola) e outra para as crianças menores de 4 anos (programas de desenvolvimento). É possível destacar também a ênfase, dada no Fórum, ao conceito de educação integral e qualidade como dever do Estado para garantir o acesso das crianças a essa educação e, de modo especial, para aquelas desfavorecidas, em situação de vulnerabilidade social, ideias que tomaram especial força nos primeiros anos do século XXI na América Latina, quando alguns países criaram "sistemas de proteção integral à infância" a fim de construir políticas com caráter integrado interdependente, sociais e educativas, além de sistemas educacionais com "garantia de qualidade" a partir de indicadores definidos externamente.

Assim, é possível perceber como a EI foi inserida nos discursos educacionais dos governos a partir, em grande parte, das intenções dos organismos internacionais. Se, inicialmente, a luta era para proteger as crianças e assegurar sua sobrevivência e cuidado, paulatinamente a importância da definição de seus direitos e de seu reconhecimento como sujeitos de direitos - sendo esta a matriz orientadora das lutas, dos movimentos sociais em prol das crianças e de sua educação - tem ocupado espaço nos discursos e agendas públicas, embora, atualmente, pareça haver uma apropriação dessa reivindicação pelos organismos 
internacionais, mas sob outra ótica, ou seja, transferindo a educação, e/ou as instituições de educação, do campo dos valores culturais para a lógica do valor econômico.

Não há qualquer exagero em afirmar, portanto, que as transformações efetivadas no plano transnacional têm influenciado os ajustes da estrutura e a atuação dos Estados latinoamericanos, encontrando-se estes permanentemente ancorados a modelos compartilhados internacionalmente. A entrada franca dos organismos internacionais nas orientações das políticas públicas pode ser caracterizada, de acordo com Gentilli (2002), por duas tendências: o instrumentalismo e o condicionamento. De modo especial, organismos de financiamento, como Banco Mundial e FMI, fundamentam suas orientações subordinando a política social à dinâmica mais ampla da lógica econômica, tendo como objetivo principal apoiar, respaldar e legitimar os programas de ajuste, o que revela o caráter instrumental dessas indicações. Ao mesmo tempo, as políticas educacionais são pensadas a partir da lógica custo-benefício, sendo enfatizadas as taxas de retorno dos recursos investidos. O condicionamento se expressa na forma como esses organismos realizam empréstimos e como financiam certos programas setoriais da região.

Porém, pensar que os governos de América do Sul levaram em consideração as concepções internacionais de maneira causal e homogênea é simplesmente uma conclusão precipitada. No âmbito interno, cada país buscou adequar suas políticas de Educação Infantil e os modos de implementação ao padrão internacional de modernização, processo enormemente complexo, que merece atenção e estudo. De acordo com os objetivos desta pesquisa, a seguir se apresenta a descrição do Chile e do Brasil, salientando os principais movimentos de organização do Estado e as tensões na configuração de políticas públicas de Educação Infantil.

\section{$2.2 \mathrm{O}$ contexto chileno}

Embora o clima social e político no Chile tenha mudado drasticamente com a volta da democracia, em 1990, depois de dezessete anos de ditadura, é fundamental explicitar que grande parte das transformações na educação de infância neste país tem a sua gênese no regime militar. Para tais fins, a configuração das políticas públicas de EI será descrita através de três momentos chaves na organização do Estado, salientando as principais políticas públicas, mudanças legais e de gestão educativa. Será apresentado também um quarto ponto, 
com dados estatísticos que mostram a evolução da EI chilena ao longo do tempo e conclusões preliminares.

\subsubsection{Educação Infantil chilena na ditadura (1973-1990)}

O período ditatorial instalou no Chile um complexo cenário fundado no neoliberalismo como doutrina econômica e em uma nova concepção de Estado que condicionou as políticas públicas. Embora o Estado constituído pelo governo do ex-presidente Salvador Allende tenha sido interrompido pelo golpe militar, a maioria das reformas ditatoriais obedeceu a uma nova lógica de mercado (competição, eleição), subsidiariedade estatal (focalização e privatização) e descentralização territorial (OLIVA, 2008) que, influenciadas pelo governo estadunidense e pelas políticas do Banco Mundial7, sustentaram a redução da ação pública estatal e deram espaço à intervenção de setores particulares e esferas municipais de gestão nas diferentes áreas. Nesse sentido, a situação das políticas públicas para a infância na ditadura esteve marcada por sinais contraditórios: enquanto que, por um lado, a focalização de programas sanitários e assistenciais para os setores desfavorecidos da população teve sucesso e propagou uma imagem estatal benévola de proteção, por outro, os conflitos políticos, estruturais e econômicos repercutiram na qualidade de funcionamento das políticas e programas nacionais.

Com o general Pinochet na presidência da República, instaurou-se uma nova ênfase na forma de entender a Educação Infantil nomeada como Educación Parvularia. O novo foco se inscreveu na refundação de uma sociedade apoiada na descentralização e no conceito de Estado subsidiário. Desde o ponto de vista estrutural, foi estabelecida a diferenciação entre creche ou "Jardin Infantil" e pré-escola ou "Pre-Básica". As políticas públicas para a Educação Infantil na creche foram elaboradas pelo Ministério do Interior e pela Corporação Nacional para a Alimentação e Nutrição (CONPAN), com grande ênfase no desenvolvimento de programas temporais de assistência e de baixo custo, focalizados no bem-estar sanitário,

\footnotetext{
${ }^{7}$ Segundo as diretrizes do Banco Mundial, de acordo com o exposto por Oliva (2008), o maior envolvimento da sociedade está na implementação de serviços sociais, e a retirada do Estado cujo papel passou a ser o de um órgão distribuidor e catalisador de recursos só em algumas áreas específicas. Nessa lógica, o setor privado pode ter participação em serviços de atenção primária e educação que, anteriormente, eram de domínio absoluto da esfera pública. Pode-se observar, em alguns contextos latino-americanos influenciados pela coerência bancária, novas modalidades de combinações públicas e privadas e, em outros, onde o Estado se retira por completo, permitindo aos grupos privados com e sem fins de lucro que se ocupem da prestação dos serviços, estabelecendo assim uma nova relação entre Estado e sociedade civil.
} 
alimentício e de cuidado das crianças, não existindo canais formais de coordenação entre os organismos executores JUNJI - Junta Nacional de Jardines Infantiles - e FUNACO Fundación Nacional de Ayuda a la Comunidad -; enquanto as políticas para a pré-escola foram coesas ao Ministério de Educação que incluiu a pré-escola em toda sua organização legislativa e curricular.

Toda essa estruturação institucional no Chile obedeceu a uma política maior de descentralização do Estado, sustentada pela Constituição Política promulgada em 1980. O sistema educativo implementado pelo governo militar destacou quatro aspectos fundamentais que permitiram o seu reconhecimento como uma enorme reforma, na época considerada como Modernização da Educação, cujos pilares permanecem até hoje:

Primeiro, a transformação do papel do Estado na educação, com a mudança de uma democracia liberal e um Estado intervencionista para uma ditadura com estado subsidiário; segundo, a transformação do sistema de financiamento da educação; terceiro, a passagem dos estabelecimentos escolares do Ministério de Educação aos municípios; e, finalmente, a modificação da estrutura do cargo de professor, que perdeu o status de funcionário público. (OLIVA, M., 2008, p.215 - tradução minha)

Seguindo esta linha, o governo militar redefiniu a administração territorial do país e transferiu uma significativa parte dos serviços sociais, entre estes, a educação, aos municípios e alguns agentes particulares. O Ministério de Educação reteve as funções normativas, de supervisão técnica e de fiscalização, enquanto municípios e mantenedores particulares assumiram a gestão das instituições, assim como do modelo de financiamento, que foi baseado em subvenções.

O sistema de subvenções ou "vouchers" foi um modelo de financiamento considerado, no discurso governamental, como a forma de promover o ingresso à educação pública de crianças de setores vulneráveis. Um sistema em que o Estado outorgava ao estabelecimento educacional um valor fixo por aluno presente, de acordo com a média de assistência mensal, sendo esse benefício também concedido a crianças de 4 a 6 anos que estavam matriculadas na pré-escola. Dessa maneira, as instituições municipais e aquelas dependentes de mantenedores particulares foram chamadas de "subvencionadas", embora estas ultimas contassem com apoio econômico estatal, estas entidades eram administradas por particulares, os quais também podiam cobrar mensalidade às famílias pela educação. Com a verba obtida, foram habilitadas pré-escolas dentro das instalações escolares e aumentaram as

\footnotetext{
${ }^{8} \mathrm{O}$ chileno foi o primeiro sistema educacional no mundo em que se adotou, em escala nacional, o "Voucher" proposto pelo economista estadounidense e defensor da economia de livre mercado, Milton Friedman. Quase um quarto de século mais tarde, sua conveniência ainda é discutida nos principais debates de política educacional nos EUA, onde apenas foi adotada a escala local em alguns estados.
} 
vagas, favorecendo mais crianças a ingressarem na Educação Infantil; porém, desde a lógica de mercado instalada, foram introduzidos mecanismos de competitividade por matrícula, recursos e rankings entre as instituições municipais e "particulares subvencionadas". Os estabelecimentos educacionais concorriam para captar alunos, muitos funcionando no limite máximo permitido, mesmo que o estabelecimento não contasse com os recursos humanos, materiais e a infraestrutura necessária para tais objetivos. O modelo via nessa competitividade um mecanismo eficiente para melhorar a qualidade da educação; as famílias teriam informação dos resultados da escola, escolheriam as melhores e tirariam seus filhos das piores, o que se traduziria em uma pressão constante por produzir resultados "de qualidade" (COX, 1997). Ampliou-se, dessa forma, a tipologia das instituições educativas existindo, até hoje: a) escolas públicas municipais gratuitas com financiamento estatal completo; b) escolas particulares subvencionadas que contam com pagamento mensal das famílias e subvenção estatal; e c) escolas particulares sem intervenção econômica do Estado.

Independente das consequências que esse tipo de sistema trouxe para a concepção de educação no Chile, o certo é que objetivamente a instalação do sistema de subvenções permitiu a abertura de vagas para que mais crianças ingressassem na pré-escola, e o investimento desses recursos econômicos por parte de algumas instituições em oferecer um ambiente pré-escolar que atraísse mais alunos - e, com isso, mais recursos econômicos validando, assim, a inclusão dessa etapa como forma de assegurar os "lucros" dos "serviços" educativos.

A municipalização, por sua vez, foi parte da política concebida como medida fundamental na descentralização do país. Em junho de 1980, o governo sancionou a normativa legal que facilitava a transferência das escolas públicas aos municípios, processo que se completou em 1986, com a ordem presidencial que obrigou a transferir a totalidade dos estabelecimentos. Conforme ressalta Sanchez (1985), podem-se listar seis objetivos da municipalização: i) melhorar a administração do sistema educacional; ii) dar maior participação à comunidade local; iii) gerar igualdade de oportunidades educacionais a todas as crianças em idade escolar, aumentando a quantidade de instituições nos setores pobres, especialmente em idade pré-escolar e escolar; iv) melhorar a qualidade de ensino; v) incrementar o gasto público em educação; e vi) aumentar os salários e as perspectivas laborais do magistério. O município assumiu o compromisso com a manutenção das infraestruturas escolares, a contratação e a demissão de pessoal, e a dotação de insumos necessários, através da criação do Departamento de Educación Municipal (DAEM), cuja equipe também assumiu a supervisão das subvenções nos centros e da aplicação dos currículos nacionais. Dessa 
forma, os municípios, junto com os centros particulares subvencionados ${ }^{9}$, legitimam-se como encarregados diretos das instituições educativas, um estilo de descentralização educativa que no Chile paradoxalmente ocasionou uma completa dependência das instituições em termos administrativos e curriculares. As redes municipais e os "mantenedores" particulares subvencionados assumiram a função de distribuidores dos recursos econômicos, e o Ministério de Educação centrou seu poder nas decisões relacionadas às orientações curriculares nacionais. Seguindo essa linha, esse modelo de gestão do sistema trouxe grandes dificuldades:

\begin{abstract}
O poder que recaiu nos mantenedores municipais e particulares não guardou relação nenhuma com as suas capacidades técnicas e pedagógicas. Fato claramente reconhecido pelos docentes de estabelecimentos municipais e particulares subvencionados, pois a maioria destes não contava com equipes técnicas qualificadas que tomassem as decisões escolares. Pelo contrário, a maior parte das decisões eram tomadas pelo poder central sob o critério de maximização dos lucros (CORNEJO, R., 2006, p. 13 - tradução minha).
\end{abstract}

O status do município pôde ter significado uma importante contribuição para a consolidação da gestão local, não obstante, na prática, a crise econômica do período ditatorial tenha contribuído para a redução paulatina de recursos fiscais entregues aos municípios e gerado práticas variáveis de gestão. A diferença de recursos recebidos dos municípios urbanos, dos rurais e das zonas extremas do país - diferenciação originada pela variabilidade na quantidade de alunos - e o corte da verba municipal, decorrente da crise de 1980, prejudicou enormemente a distribuição de recursos para os diferentes níveis de ensino. Os municípios priorizaram investir no Ensino Fundamental obrigatório, em detrimento da Educação Infantil, esta última etapa sofrendo gradualmente a diminuição de pessoal especializado em infância dentro da sala de aula -- de acordo com a proporção criança/adulto - e a falta de insumos para realizar as atividades, o que produziu, em vários casos, apenas a manutenção de programas de atendimento de baixo custo. Aliás, toda esta essa metamorfose política e estrutural afetou em grande medida os docentes de Educação Infantil, os quais perderam a condição de funcionários públicos para se tornarem empregados diretos dos municípios ou dos mantenedores particulares. No caso das Educadoras de Infância, a ampliação de pré-escolas favoreceu a oportunidade de vagas de emprego, mas a nula intervenção do Estado na regulação das condições trabalhistas gerou grandes diferenças

\footnotetext{
${ }^{9}$ Cabe destacar que grande parte dos estabelecimentos particulares subvencionadas nas décadas de 1970 e 1980 no Chile dependia de congregações religiosas cujo envolvimento e exercício de poder nos processos do Estado foi característico no Chile na ditadura.
} 
salariais entre os diversos tipos de instituições e a diminuição salarial de até um terço do valor original.

As mudanças educativas, entre os anos 1973 e 1990, surgiram para enfrentar a urgência do "grave problema" da educação pública do regime popular do ex-presidente Salvador Allende e o fracasso do Estado provedor. Este relato faz parte de um discurso antiestatista, no qual se critica um Estado como "inoperante e burocrático" (FALABELLA, 2014). As mudanças foram justificadas a partir de três eixos diretivos, os mesmos preconizados pelo BM: Estado subsidiário, descentralização/expansão do setor privado e supremacia da liberdade do ensino. Estes eixos foram consolidados em dois documentos sancionados no governo militar: A Constituição Política, de 1980, e a Ley Orgánica Constitucional de Enseñanza (LOCE), aprovada em 1989. Ambos reúnem a complexa gama de modificações educativas deste período.

Na Constituição ${ }^{10}$, a educação se estabelece como direito fundamental do ser humano e o exercício dele é dever primordial da família com respeito aos filhos. O Estado aparece apenas como protetor e garante do cumprimento da função familiar.

Art. 10 - O direito à Educação

A educação tem por objetivo o pleno desenvolvimento da pessoa nas distintas etapas da sua vida. Os pais têm o direito preferente e dever de educar aos filhos. Corresponderá ao Estado outorgar especial proteção ao exercício de este direito.

O Estado promoverá a Educação Parvularia, sem ser obrigatória.

A Educação fundamental é obrigatória, devendo o Estado financiar um sistema gratuito com tal objeto, destinado a assegurar o acesso a elas de toda a população (...)

Nota-se que a Educação Infantil, situa-se no núcleo privado da família, e o papel do Estado é proteger essa liberdade individual, o que substituiu o ideário republicano da educação como direito e bem social.

O princípio subsidiário do Estado também está normatizado na Constituição, advertindo uma clara intenção de privilegiar a competitividade e estabelecendo o direito de "livre ensino" para os mantenedores municipais e particulares.

Art.11- A liberdade de ensino inclui o direito de abrir, organizar e manter estabelecimentos educacionais. A liberdade de ensino não tem outras limitações que as impostas pela moral, os bons costumes, a ordem publica e a segurança nacional. (...). É preocupação preferente do Supremo Governo estimular a criação de instituições particulares de ensino que integrem o sistema educacional, ajustando-se aos planos e programas oficiais. É de toda conveniência propender a um adequado financiamento da educação particular que não persiga fins de lucro, outorgando-lhe

\footnotetext{
${ }^{10}$ Nota: Todos os artigos e trechos de documentos legais e oficiais do Chile foram traduzidos por mim.
} 
o direito de impetrar o benefício de uma subvenção que lhe permita cobrir gastos que demanda sua gestão docente administrativa.

Os pais têm o direito de escolher o estabelecimento de ensino para seus filhos.

\section{O princípio descentralizador do Estado que sustenta a municipalização também se} esclarece nesta Constituição Política:

Art.3 - O Estado de Chile é unitário, seu território se divide em regiões. Sua administração será funcional e territorialmente descentralizada ou desconcentrada em conformidade com a lei.

Art.17 - A administração de cada cidade reside no município, a qual estará constituída pelo prefeito, que é a máxima autoridade, e uma equipe de gestão em cada área (....). Os municípios são corporações autônomas de direito público, com responsabilidade jurídica e patrimônio próprio, cuja finalidade é satisfazer as necessidades da comunidade local e assegurar sua participação no progresso econômico, social e cultural da cidade (...).

Art. 110 - Os municípios para o cumprimento das suas funções poderão criar ou suprimir empregos e fixar remunerações, como também instaurar órgãos ou unidades que a lei permita (...)

Art.111 - Os municípios terão autonomia absoluta para a administração de suas finanças. A lei poderá outorgar-lhes recursos para atender seus gastos sem prejuízo dos recursos que possam administrar autonomamente, ou que sejam conferidos por outras normas de distribuição dos fundos municipais.

A Lei Orgânica Constitucional (LOCE) estabeleceu os requisitos mínimos que são exigidos em cada um dos níveis de ensino e sinalizou as normas objetivas de aplicação no reconhecimento dos estabelecimentos educacionais de ensino pré-escolar, fundamental e médio, assim como nas instituições de educação superior.

Nos trechos que abordam a Educação Infantil, destacam-se os seguintes artigos:

Art.6- A Educação Infantil é o nível educacional que atende integralmente crianças desde o seu nascimento até seu ingresso no ensino fundamental, sem constituir antecedente obrigatório para isso. Seu propósito é favorecer de maneira sistêmica, oportuna e pertinente os aprendizados relevantes e significativos para os alunos, apoiando a família no seu papel insubstituível de primeira educadora. A Educação Infantil não exige requisitos mínimos para acesso, nem permite estabelecer diferenças arbitrárias.

Art.21- Os requisitos para o reconhecimento oficial dos estabelecimentos que transmitam ensino pré-escolar serão os seguintes:

a) Ter um mantenedor que cumpra os requisitos estabelecidos e que não tenha sido condenado à pena aflitiva;

b) Ter um projeto que tenha como referência as Bases Curriculares da Educação Infantil chilena, elaboradas pelo Ministério de Educação;

c) Contar com pessoal idôneo e qualificado;

d) Dispor de mobiliário, equipamento e materiais didáticos necessários, de acordo com os níveis de atendimento;

e) Acreditar que o local onde funciona o estabelecimento cumpre com as normas gerais de aplicação previamente estabelecidas.

Esses requisitos serão regulamentados mediante Decreto Supremo do Ministério de Educação. 
Sem ter pretensões de analisar profundamente o Estado chileno na ditadura, cumpre esclarecer os aspectos políticos, econômicos e legislativos que influenciaram a configuração das políticas públicas de Educação Infantil. A dicotomia entre creche e pré-escola sustentada pela distinção de suas funções, instituições responsáveis e princípios dominantes; o estilo de financiamento subsidiário do Estado que determinou o funcionamento das pré-escolas; a municipalização e a legitimação das instituições particulares envolvidas com educação pública; e a perda de valorização docente foram elementos distintivos desse período. Embora o Chile tenha conseguido reduzir a desnutrição infantil, aumentar a expectativa de vida e ampliar o acesso de crianças à educação, a maior crise econômica desatada na década de 1980 e o consequente aumento do desemprego que chegou a 30\%, a forte repressão social vivida pela população com situações de violência, perseguição, morte e exílio, submeteu à realidade chilena a uma profunda desigualdade e converteu-se no retrato do sistema educacional da época: um incremento da quantidade de famílias em condição de pobreza e segregação.

\subsubsection{O Estado Compensatório (1990-2005)}

No início da década de 1990, a educação chilena exibiu índices positivos na cobertura do ensino fundamental, ampliação da escolaridade média e redução do analfabetismo, principalmente pelo aumento de instituições escolares particulares subvencionadas e pela medida constitucional da obrigatoriedade do ensino fundamental. Em contraste, na EI foram registrados baixos índices relacionados à inequidade na sua distribuição, resultante da redução do gasto público, e a deficiente gestão das redes provedoras, que deteriorou o funcionamento dos centros de atendimento e a situação laboral dos seus professores.

A volta da democracia significou para a Educação Infantil uma enorme tarefa de "normatização". A dissociação entre creche e pré-escola, traduzida na institucionalização dispersa da creche, e a relação clientelística entre a pré-escola e as famílias, não equiparou as realidades de ensino, e terminou legitimando as desigualdades entre escolas municipais e particulares subvencionadas, estas últimas com melhores condições devido ao ingresso de recursos mistos e ao gradual aumento da população estudantil cuja escolha avançou de 7\%, em 1980 a 37\%, no ano de 2001 (MINEDUC, 2005). A autonomia "disfarçada" dos municípios, dos centros educativos, dos educadores, da comunidade e o rol passivo das crianças em torno aos processos educativos que priorizavam o assistencialismo foram a motivação para necessárias mudanças nas políticas públicas, e também para a incorporação de 
novos paradigmas internacionais que permitissem uma gestão pela melhoria da qualidade de educação, conceito cada vez mais presente na agenda nacional.

O fim do governo militar no ano de 1990 coincide com a ratificação da Convenção dos Direitos da Criança pelo governo chileno frente às Nações Unidas e com a participação signatária em outros compromissos mundiais em defesa dos direitos da infância como a Cúpula Mundial pela Infância e a Conferência Mundial de Educação para Todos. Embora as primeiras emergências sobre a preocupação com os direitos infantis tenham surgido em plena ditadura, no ano de 1979, nomeado "Ano Internacional da Criança", foi na volta da democracia e nos sucessivos governos da Concertación $^{11}$ que a decisão política de garantir explicitamente a proteção das crianças menores de 18 anos significou um compromisso do Estado na tomada de providências para possibilitar a sua aplicação, sobretudo frente ao tema da violação dos direitos humanos no período militar e à grande quantidade de crianças em situação de pobreza. Temas como: desenvolvimento infantil e educação das crianças pequenas; educação fundamental; saúde materno-infantil; nutrição; saneamento e higiene; trabalho infantil; responsabilidade penal; abandono e abuso sexual; entre outros, foram os que concentraram maior quantidade de mudanças.

Tal como expõe Rojas,

\begin{abstract}
A doutrina dos direitos da criança, que em rigor aplica-se também aos adolescentes, provocou vários efeitos no plano legal, porém a ideia da defesa dos direitos infantis se fez recorrente também no discurso governamental e seus alcances superaram o estrito campo do direito, penetrando por diversas vias na população e instalando-se no cotidiano. (ROJAS, 2010, p. 33 - tradução minha)
\end{abstract}

Nos primeiros governos da Transição Democrática (1990-2005), a educação foi declarada como prioridade fundamental, com base na garantia do direito educativo das crianças dentro da função "promotora" do Estado, e como elemento estratégico para "o fortalecimento de uma sociedade mais justa e equitativa em vias de desenvolvimento" (Ibidem, p.36). O conjunto de políticas dos anos 1990 provocou uma ampliação do papel do Estado, não apenas desde a função tipicamente subsidiária, senão de um papel promotor e responsável que intervém, outorga recursos e supervisiona os marcos institucionais, tanto os objetivos de qualidade como da equidade do sistema na sua totalidade. Essa função apoiaria a especificidade da natureza da ação pública na educação, que começou a surgir nessa época:

\footnotetext{
${ }^{11}$ O bloco da Concertación foi a coalizão política que derrotou o regime militar nas eleições de 1989 e que deu passo ao primeiro governo democrático. Essa aliança contou com o apoio dos partidos socialista, comunista, o Movimiento de Izquierda Revolucionaria $(M I R)$ e a parte esquerdista do partido democrata cristão, do qual o primeiro presidente Patricio Aylwin foi secretário geral.
} 
programas integrais de intervenção, de cobertura universal para crianças de 0 a 6 anos, para a melhoria da qualidade das aprendizagens, e programas compensatórios focados nas instituições de menores recursos, para a melhoria da equidade (COX, 1997 - tradução minha).

A missão principal da esfera pública foi reestabelecer as ideias fundantes da Educação Infantil chilena e os critérios de qualidade, expressados antes da ditadura "como o desenvolvimento integral das crianças e a participação da comunidade na construção de projetos educativos" (PERALTA, 2010, p.8 - tradução minha). Não obstante, o cenário social também determinou uma rápida tomada de decisões para implementar medidas em torno das deficiências decorrentes da ditadura, principalmente as relacionadas à vulnerabilidade e aumento de famílias em condição de pobreza. Foi planejada uma reforma do sistema educacional em crise, sem modificar sua estrutura original. Os propósitos dessa reforma buscavam remediar os efeitos negativos em torno da severa desigualdade entre alunos de escolas municipais e particulares subvencionadas, causados pela redução do gasto fiscal, em coerência com a Constituição de 1980, a LOCE - os artigos referentes à educação nesses dois documentos não foram emendados - e os princípios internacionais da Convenção dos Direitos da Criança, aspectos orientados por similares instrumentos de Estado/Mercado, modelos de municipalização e financiamento do período anterior.

O governo, como dito, estimou como pilares da reforma os conceitos de equidade de acesso e qualidade educativa, eixos imprescindíveis para investir na Educação Infantil, acreditando que as aprendizagens na etapa inicial da vida constituem fator determinante no futuro escolar das crianças, especialmente para aquelas provenientes de famílias pobres, para quem a escola pode significar o lugar para desenvolver competências e enriquecer a linguagem, e, com isso, reduzir os índices de fracasso escolar nos primeiros anos da escola primária. As políticas foram orientadas de acordo com o critério de "direito universal" de oportunidades das crianças ao acesso às instituições, e com a estratégia de discriminação positiva, segundo a qual a igualdade de oportunidades educativas para grupos heterogêneos requer outorgar mais recursos e prestar mais atenção ao segmento mais vulnerável da população $^{12}$. Assim, a ação governamental configurou-se em torno de três reformas nas políticas de Educação Infantil: de reorganização estrutural, de financiamento e de referencial curricular, as quais serão detalhadas a seguir:

\footnotetext{
${ }^{12}$ Veja-se em HeRmosilla, B. La Educacación Parvularia en la Reforma: Una Contribución a la Equidad. Ministerio de Educación de Chile, 1998.
} 


\section{a) Política de reorganização estrutural do Sistema de Educação Infantil}

Uma reformulação substancial foi elaborada para a educação de crianças de 0 a 3 anos 11 meses, na creche, nomeada como "primeiro ciclo". No novo cenário, a FUNACO modificou sua dependência institucional, passando a depender do MINEDUC e do Ministério do Interior conjuntamente, mudou sua razão social para Fundación Nacional para el Desarrollo Integral del menor (INTEGRA) e iniciou o planejamento de um projeto educativo. Foram formalizadas as vias de conexão e parceria entre INTEGRA e JUNJI - que, por sua vez, tinha voltado a depender do MINEDUC em 1987 -, contratados profissionais, capacitados trabalhadores antigos e consolidados convênios com a UNICEF e as Universidades. O "segundo ciclo" incluiu o atendimento de crianças de 4 a 6 anos, em níveis denominados Transição I (Pre-kinder, de 4 a 5 anos) e Transição II (Kinder, de 5 a 6 anos).

Todavia, a maioria das mudanças na organização institucional da Educação Infantil pública obedeceu a um ordenamento de funções, já que os dois ciclos continuaram trabalhando isoladamente e de modo distinto. As normas de fiscalização, financiamento e de provisão de serviços ficaram como responsabilidade de distintas entidades.

Tabela 2 - Instituições Responsáveis pela Educação Infantil Pública Chilena

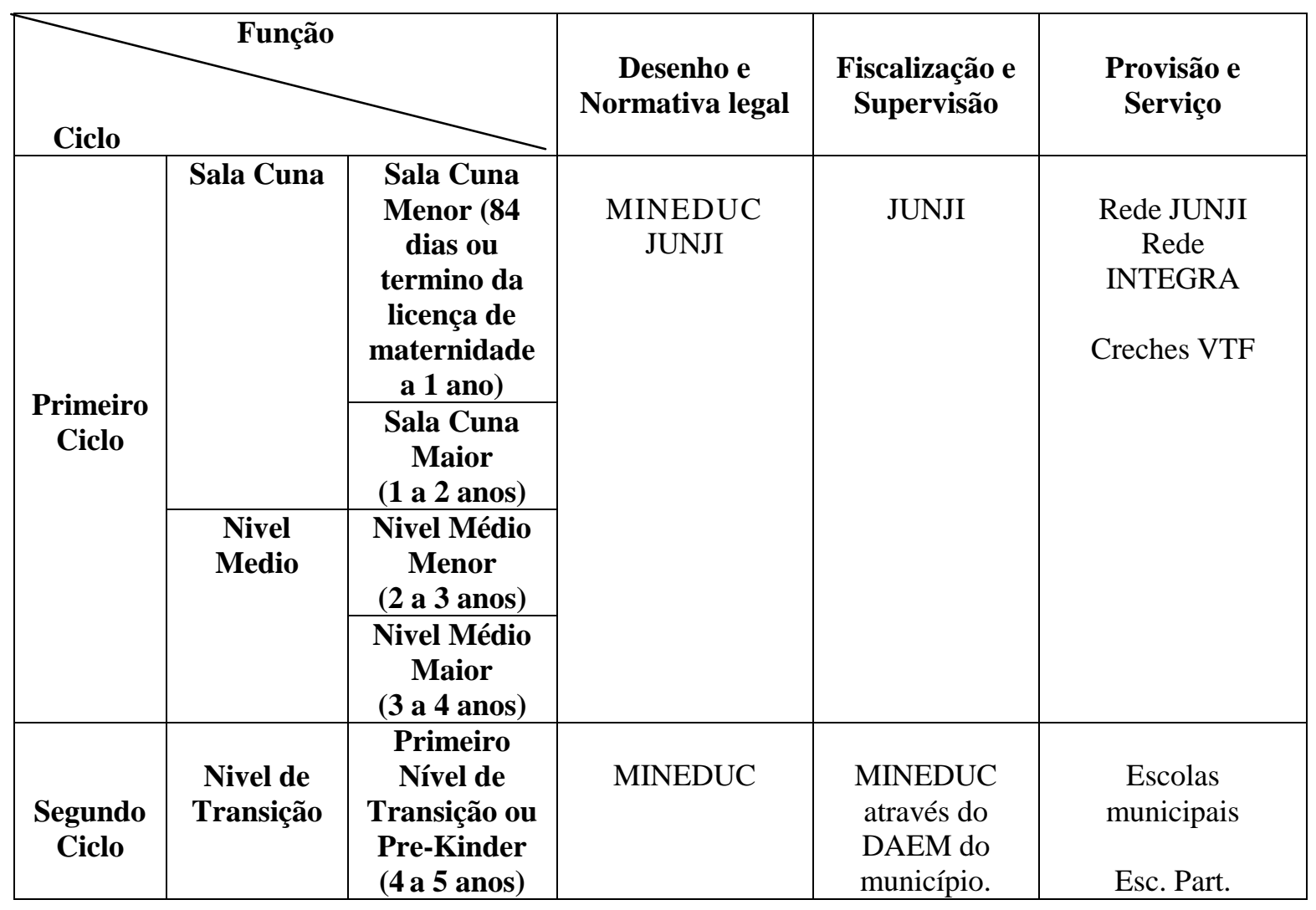




\begin{tabular}{|l|c|c|l|l|}
\hline & Segundo & & & Subvencionadas \\
& Nível de & & & \\
Transição ou & & & & \\
Kinder & & & & \\
\hline
\end{tabular}

Fonte: MINEDUC, Antecedentes Generales del Nivel de Educación Parvularia en Chile, 2014

Como se observa, a organização institucional que operou desde 1990, embora tenha buscado integrar e sistematizar a responsabilidade pública da creche e da pré-escola, a JUNJI e a MINEDUC respectivamente, continuou dividindo a dependência administrativa das instituições, coerente com o modelo misto (público e privado) do resto do sistema educacional e, portanto, sujeita às mesmas críticas da época do regime militar. O município, como esfera governamental, não tem gerência no desenho de políticas públicas e tomada de decisões na Educação Infantil, pois figura como mero fiscalizador e executor dentro da organização institucional.

\section{b) Política de Financiamento}

Quanto ao financiamento, os dois ciclos também continuaram divididos, de acordo com a natureza das fontes financiadoras. No primeiro ciclo, a JUNJI começou a receber recursos econômicos provenientes diretamente do Estado - MINEDUC e MIDEPLAN -, segundo critérios que não tiveram relação com a oferta das creches nem com as características das crianças $^{13}$. A INTEGRA, por sua parte, recebeu verba fiscal e privada, esta última proveniente de corporações particulares e ONGs. Destaca-se a legitimação e a integração das creches "Via Transferencia de Fondos" (VTF), com um sistema similar às pré-escolas particulares subvencionadas e administradas por terceiros, com recursos mistos repassados pelas Secretarias Municipais e pelas famílias.

De modo diferente no segundo ciclo, o MINEDUC entregou recursos aos municípios e mantenedores particulares subvencionados para o funcionamento das pré-escolas seguindo o modelo de subvenções instaurado na ditadura. No caso do município, a verba recebida devia ser distribuída entre as pré-escolas da rede municipal e as creches VTF. Segundo a pesquisa de Tokman (2010), embora até o ano 2000, os valores entregues por aluno tenham sido quase os mesmos que os outorgados para o ensino fundamental, a idoneidade da subvenção como única forma de cálculo do financiamento para pré-escola e creche era discutível, dados os

\footnotetext{
${ }^{13}$ Em grande parte dos casos, os recursos econômicos recebidos tiveram a ver com critérios de ordem institucional como, por exemplo, localização geográfica da instituição, quantidade de empregados, estilos de programas educativos e assistenciais que implementam: por temporada, em zonas extremas, apoio às famílias, etc.
} 
altos graus de ausência das crianças menores de seis anos e a alta proporção de custos fixos (pessoal e infraestrutura). O município, mesmo tendo autonomia administrativa sobre os recursos, legalmente não está obrigado a gerar recursos próprios e destiná-los à educação. Porém, o fundo recebido do MINEDUC muitas vezes não era suficiente para cobrir as despesas educativas, sendo estas então arcadas pelo município, que nem sempre priorizava a EI.

Não obstante, a injeção de recursos econômicos pelo Estado na Educação Infantil foi triplicada no período 1990-2005, principalmente para incrementar a quantidade centros educativos, sendo este um dos pilares da Reforma. Cabe salientar que o intuito de expansão do Estado veio ligado à implantação de uma série de políticas sociais - como merenda escolar, caixas de materiais escolares, atenção nutricional e dental - para crianças provenientes de famílias vulneráveis ou com baixa avaliação $C A S^{14}$, como forma de assegurar o acesso e a permanência de todas as crianças dentro das instituições públicas e como compromisso político do Estado com a garantia do patamar mínimo de condições nessa etapa educativa.

Assim, concomitante à reorganização institucional e financeira, as políticas nacionais orientadas a incrementar o gasto público para assegurar cobertura na Educação Infantil tiveram grande sucesso nos primeiros governos democráticos; o incremento em matrículas, junto à população de crianças em idade de 0 a 6 anos decrescendo, levaram a duplicar a taxa de vagas, chegando a $38 \%$ no primeiro ciclo e a $65 \%$ no segundo ${ }^{15}$, no período entre 1990 e 2006.

Na correlação matrículas-vagas, observou-se um fenômeno demográfico importante: ainda que a quantidade de vagas aumentasse, o número de crianças no Chile reduziu. Esse fenômeno, visto pela ótica estrutural, facilitou a disponibilidade dos centros de Educação Infantil; porém, na medida em que se incorporaram mais crianças ao sistema, as que ainda faltavam eram crescentemente mais difíceis de captar. Ademais do fator demográfico, outros elementos da oferta e demanda incidiram nos índices de cobertura observados, principalmente porque o incremento de cobertura foi diferente segundo a dependência das instituições. A constante concorrência entre instituições com financiamento misto em relação às instituições municipais significou a continuação da migração de famílias a instituições particulares

\footnotetext{
${ }^{14}$ A avaliação CAS ou "ficha CAS" é o instrumento único utilizado no Chile desde 1980 para focalizar os programas sociais nos setores mais vulneráveis. A partir de um modelo de cálculo matemático e designação de pontos a diferentes variáveis, fatores e subfatores, é possível classificar os grupos familiares em cinco níveis ou índices de pobreza, sendo os três primeiros os que refletem as situações mais severas. Desta forma se identificam e selecionam os potenciais beneficiários de programas sociais e políticas focalizadas.

${ }^{15}$ Fonte: Andrea TOKMAN, "Radiografía de la Educación Parvularia Chilena: Desafíos y Propuestas", 2010.
} 
subvencionadas, por considerá-la de "melhor qualidade". A paulatina desvalorização da Educação Infantil municipal, portanto, deixou aos municípios menos financiamento, e ainda lhes atribuiu a missão de reter as crianças mais pobres e de setores vulneráveis específicos (filhos de trabalhadores temporários, mineiros e pescadores), com maiores possibilidades de desistência e características contextuais específicas, que não podiam ser cobertas na totalidade por causa do limitado financiamento.

A despeito dos importantes avanços em cobertura e de alguns relatórios da OCDE e da $\mathrm{CEPAL}^{16}$, que apresentam estatísticas que deixaram o Chile dentre os países de América Latina com maior investimento em Educação Infantil no período, há pouca informação e poucos dados estatísticos que evidenciem a baixa participação dos municípios no processo, em relação ao aumento do setor particular subvencionado, o que revelaria a permanência deste estilo de segmentação educativa que parecia ser legitimada mais uma vez.

\section{c) Política de Referencial Nacional Curricular}

A reforma educacional da década de 1990 renovou os currículos de todos os níveis de ensino. A decorrente heterogeneidade curricular entre o primeiro e segundo ciclo foi vista como um obstáculo na hora de definir e avaliar a qualidade educativa externamente, pelo que foi preciso revisar objetivos essenciais para as crianças menores de 6 anos e articular de forma pertinente todos os níveis de Educação Infantil, e estes com os de Ensino Fundamental. Foi elaborado, então, um referencial curricular nacional para a educação das crianças, desde o nascimento até o ingresso ao ensino fundamental, inicialmente com a flexibilidade de ser adaptado a distintas realidades educativas. O processo de construção das Bases Curriculares Nacionais exigiu inicialmente uma consulta nacional a profissionais, acadêmicos e pesquisadores da área de Educação Infantil e educadores de todos os tipos de instituições do país, para definir os patamares da proposta curricular e selecionar os objetivos gerais de cada nível, princípios pedagógicos e organização de conteúdos. Após a sistematização das opiniões, a equipe encarregada do MINEDUC realizou uma segunda consulta a especialistas em currículos nacionais e internacionais para, em 30 de junho do ano 2000, apresentar as bases desse documento, as quais afirmavam que:

(Espera-se) privilegiar um currículo que potencialize as possibilidades das crianças, enfatizando-as nas suas forças e não apenas nas suas carências.

Fortalecer temas como a formação em valores, a importância da família como primeira educadora e a busca do bem-estar pleno das crianças, a importância do brincar, a autonomia, a independência, a criatividade, entre outros.

\footnotetext{
${ }^{16}$ Segundo fontes do Relatório OCDE-Chile 2005 e do Relatório CEPAL UNESCO 2005.
} 
Relevar o respeito à diversidade das crianças e às suas famílias, e, portanto, a importância das características pessoais, étnicas, linguísticas e culturais de cada região do país.

Incorporar temas emergentes, tais como gênero, meio ambiente, prevenção de riscos, interculturalidade, entre outros.

Adotar uma visão na qual as crianças devem ser respeitadas como sujeitos protagonistas da época em que vivem.

Apresentar fundamentos filosóficos, histórico-situacionais, sócio-antropológicos, neurológicos, psicológicos e pedagógicos de forma integrada e centrados no essencial. (MINEDUC, 2001 - tradução minha)

As Bases Curriculares de la Educación Parvularia (BCEP) consolidaram-se como símbolo do compromisso do Estado com a educação de infância. Foram incluídos no texto os princípios da Convenção de Direitos da Criança e especialmente os contidos no Marco da Ação de Dakar (2000), decorrente da Conferência Mundial de Educação para Todos, na qual se reafirma o compromisso com o equilíbrio entre as intenções do que a sociedade pretendia com as novas gerações e as características próprias da infância chilena, naquela época, como interesse de governo. O referencial curricular pretendeu se instalar no sistema educacional infantil como uma ferramenta para unificar critérios comuns entre o primeiro e segundo ciclo, mas deixando espaço para as capacidades dos professores e das instituições de adaptarem as diretrizes ao contexto. A proposta de busca de novos sentidos sobre a infância, suas instituições e pedagogias, através do incentivo à tomada de decisões por parte dos municípios e instituições, que até esse momento figuravam como meros receptores e aplicadores de macropolíticas, foi um dos principais eixos motivadores. As BCEP incluíram os professores como agentes responsáveis por refletir e adaptar as diretrizes às suas práticas, resguardando a diversidade de cada realidade educativa e a singularidade das crianças que nela interagiam.

Não obstante, na implementação, as BCEP figuraram como uma tentativa de contextualização pedagógica que, no longo prazo, não conseguiu se desligar do regime educacional de mercado. A institucionalização dos processos curriculares compôs uma estratégia educativa muito similar à do ensino fundamental que, coerente com o sistema instaurado, sobrevalorizou a eficácia dos resultados em contraste com a eficiência dos processos educativos variáveis das crianças nessa etapa educativa. Foi estabelecida como prática comum que as redes JUNJI, INTEGRA, municípios e mantenedores particulares subvencionados elaborariam seus projetos curriculares através de "copia e cola" das BCEP e os aplicariam de maneira homogênea nas instituições, o que favoreceu práticas autoritárias pela utilização de padrões curriculares descontextualizados. Aliás, na dinâmica de concorrência, as escalas de avaliação para crianças foram arbitrariamente incluindo conteúdos 
de ensino fundamental - alfabetização, operações matemáticas básicas - denominando creche e pré-escola de "qualidade" àquelas capazes de preparar melhor as crianças para o nível de ensino seguinte.

Sob essa lógica, o MINEDUC elaborou outros instrumentos derivados da Base Curricular Comum, como os Mapas de Progreso de los Aprendizajes e os Programas Pedagógicos para el Primer y Segundo Nivel de Transición ${ }^{17}$, com o objetivo de apoiar o trabalho pedagógico, mas que acabaram por estruturar e instrumentalizar ainda mais as BCEP, convertendo-as em "manuais" muito detalhados sobre o que fazer, quando e como dentro da sala de aula.

A seguir, apresenta-se um quadro resumo da organização curricular que rege os planejamentos de todas as atividades pedagógicas de Educação Infantil até hoje. Cabe destacar que tanto os âmbitos de experiências como os núcleos de aprendizagem são iguais tanto para o primeiro ciclo - de 0 a 3 anos, 11 meses- quanto para o segundo ciclo - de 4 a 6 anos-. Já os aprendizados esperados, as orientações pedagógicas e as listas de verificação variam de acordo a idade das crianças.

Tabela 2 - Componentes e Categorias de Organização Curricular (Chile)

\begin{tabular}{|c|c|c|c|c|c|}
\hline $\begin{array}{c}\text { Âmbitos de } \\
\text { experiências para } \\
\text { aprendizagem }\end{array}$ & $\begin{array}{c}\text { Núcleos de } \\
\text { Aprendizagem }\end{array}$ & Eixos de aprendizagem & \multirow{5}{*}{$\begin{array}{l}\text { D. } \\
0 \\
0 \\
0 \\
0 \\
0 \\
0 \\
0 \\
0 \\
0 \\
0 \\
0 \\
0\end{array}$} & \multirow{4}{*}{ 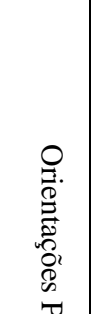 } & \multirow{4}{*}{$\begin{array}{l}5 \\
5 . \\
0 \\
0 \\
0 \\
0 \\
0\end{array}$} \\
\hline \multirow{7}{*}{$\begin{array}{l}\text { Formação pessoal e } \\
\text { social }\end{array}$} & \multirow[t]{3}{*}{ Autonomia } & Motricidade & & & \\
\hline & & Cuidado de si mesmo & & & \\
\hline & & Independência & & & \\
\hline & \multirow[t]{2}{*}{ Identidade } & $\begin{array}{l}\text { Reconhecimento e apreço } \\
\text { por si mesmo }\end{array}$ & & $\begin{array}{l}0 \\
\stackrel{0}{0} \\
0 \\
0 \\
0\end{array}$ & $\stackrel{\overparen{0}}{\overrightarrow{0}:}$ \\
\hline & & $\begin{array}{l}\text { Reconhecimento e e } \\
\text { expressão de sentimentos }\end{array}$ & है & 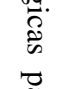 & 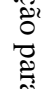 \\
\hline & \multirow[t]{2}{*}{ Convivência } & Interagem social & $\begin{array}{l}\overrightarrow{2} \\
\ddot{z}\end{array}$ & $\stackrel{\mathscr{\#}}{\approx}$ & مْ \\
\hline & & Formação de Valores & & : & $\stackrel{2}{\approx}$ \\
\hline \multirow[t]{5}{*}{ Comunicação } & \multirow[t]{3}{*}{ Linguagem Verbal } & Comunicação Oral & \multirow{6}{*}{ 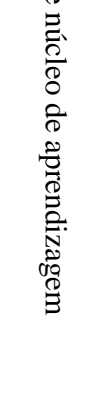 } & $\overrightarrow{\underline{g}}$ & : \\
\hline & & Iniciação à leitura & & స̃. & ڤँ \\
\hline & & Iniciação à escrita & & 8 & \\
\hline & \multirow[t]{2}{*}{ Linguagens Artísticos } & Expresão criativa & & ڤँ & $\overline{0}$ \\
\hline & & Apreciação Estética & & & \\
\hline Relação com o médio & $\begin{array}{l}\text { Seres vivos } \text { e } \\
\text { entorno }\end{array}$ & $\begin{array}{l}\text { Descobrimento do mundo } \\
\text { natural }\end{array}$ & & & \\
\hline
\end{tabular}

\footnotetext{
${ }^{17}$ Documentos disponíveis em www.mineduc.cl
} 


\begin{tabular}{|c|c|c|}
\hline \multirow{3}{*}{$\begin{array}{l}\text { natural, cultural e } \\
\text { social }\end{array}$} & $\begin{array}{l}\text { Grupos humanos, suas } \\
\text { formas de vida e } \\
\text { acontecimentos } \\
\text { relevantes }\end{array}$ & $\begin{array}{l}\text { Conhecimento do entorno } \\
\text { social }\end{array}$ \\
\hline & \multirow{2}{*}{$\begin{array}{lr}\text { Relações } & \text { lógico- } \\
\text { matemáticas } & \text { e } \\
\text { quantificação } & \end{array}$} & $\begin{array}{l}\text { Raciocínio lógico- } \\
\text { matemático }\end{array}$ \\
\hline & & Quantificação \\
\hline
\end{tabular}

Fonte: Elaboração própria a partir das BCEP, Mapas de Progreso e Programas Pedagógicos acima referidos.

A pressão exercida pelas redes educacionais JUNJI, INTEGRA, mantenedores e municípios sobre os centros educativos e os profissionais quanto ao cumprimento rigoroso desses documentos resultou em uma inevitável homogeneização do trabalho - pois os educadores se transformaram em técnicos que aplicavam algo já dado - e uma sobre escolarização imposta na Educação Infantil pública, consequências muito distantes da essencialidade original das BCEP.

No primeiro ciclo, as equipes de JUNJI, e, no segundo, as equipes técnico pedagógicas do DAEM, assumiram a fiscalização mensal do plano de trabalho curricular dentro das instituições, recebendo listas do MINEDUC para avaliar a educação a partir de indicadores presentes na sala de aula e na prática pedagógica dos professores, a qual devia ser coerente com o exposto nas BCEP. Essas listas de cotejo normalmente não se adequavam à realidade de cada instituição ou local e, ainda, contribuíram para a elaboração de relatórios anuais "posicionando" os modelos de instituições de acordo com a qualidade das práticas pedagógicas. Depois de anos de instalação, as BCEP registraram marcadas comparações entre municípios e instituições, considerando as listas de avaliação externa como único instrumento para determinar qual instituição estava "melhor posicionada".

Com os antecedentes apresentados, nota-se que o impacto das reformas no período 1990-2005 foi positivo em termos de organização, ampliação da Educação Infantil e integração dos dois ciclos -creche e pré-escola- em um momento crítico da história da educação chilena, mas cabe salientar que, após quinze anos, as consequências só puderam ser apreciadas pelas novas gerações. Durante a ultima década do século XX e o início do XXI, embora as agendas políticas buscassem equidade e qualidade através de uma Educação Infantil orientada por sentidos de democratização e direitos da criança, não conseguiram se desprender da linguagem e dos sentidos doutrinários do modelo neoliberal, fato que não assegurou melhoria da Educação Infantil e, pior ainda, manteve os índices de segregação social. 
Cabe destacar que a grande dívida desse período esteve no âmbito da formação profissional, cuja primeira mudança foi registrada em 1991 com a promulgação do Estatuto Docente mediante a Lei n 19.398, que tentou regular a carreira profissional. O Estatuto incentivou a criação do marco laboral para os educadores e assistentes do setor municipal e particular subvencionado (incluído o coeficiente técnico e a renda mínima nacional) e concedeu incentivos e programas de capacitação para docentes de todas as áreas e níveis em exercício, existindo até hoje uma diversa gama de especializações, sistemas de avaliação e reconhecimento para educadores infantis em diversas instituições reguladas e certificadas pelo $\mathrm{CPEIP}^{18}$. Porém, não existiu nenhuma política significativa na formação inicial de graduação até o final de 2005, ano em que foi sancionada a Ley de Acreditación de la Calidad de la Educación Superior que avaliou e autorizou o credenciamento dos cursos profissionais oferecidos em todas as faculdades públicas e particulares a partir da qualidade dos currículos, tipos de avaliações e estágio, qualidade dos professores e habilidades dos seus estudantes através da prova INICIA.

No primeiro registro nacional, apenas onze das noventa e oito entidades avaliadas foram aprovadas, sendo nove delas instituições públicas. Os principais indicadores deficientes revelaram que um grande número de instituições particulares de educação superior não contava com a infraestrutura necessária e recebiam alunos com baixa nota na Prueba de Selección Universitaria (PSU), pelo que as faculdades deviam gastar bastante tempo e recursos em nivelar aos seus estudantes ${ }^{19}$.

Além da diferenciação da formação de graduação dos novos professores, a diversidade de salários foi um fator que regulou a permanência de profissionais no setor público. JUNJI, INTEGRA, creches VTF e pré-escolas particulares subvencionadas tinham sistemas próprios de cálculo salarial, a partir das horas trabalhadas e dos incentivos, de acordo com metas pré-definidas. Embora o piso salarial oficial fosse único, o número de profissionais que ingressavam por concurso público no sistema municipal foi consideravelmente menor. Muitos constatavam que

\footnotetext{
${ }^{18}$ CPEIP - Centro de Perfeccionamiento, Experimentación e Investigaciones Pedagógicas- É um organismo do Ministério de Educação com a responsabilidade de promover, orientar, regular e executar ações de desenvolvimento profissional docente para apoiar os professores e professoras na sua missão de favorecer formação e aprendizado para todos os seus estudantes. Durante 48 anos, o CPEIP tem contribuído nacional e internacionalmente para a capacitação docente, com uma clara orientação à renovação de metodologias de ensino e estratégias de aprendizagem alentando desse modo a inovação nas aulas. O Estatuto Docente além conferiu ao CPEIP a tarefa de manter um Registro Público Nacional de Perfeccionamiento e a função de acreditar, avaliar e supervisar as instituições públicas e privadas para que ditem cursos de licenciatura e pósgraduação válidos. (Disponível em www.cpeip.cl, estratos - tradução minha)

${ }_{19} \mathrm{O}$ número de faculdades credenciadas tem aumentado a cada ano. Em 2014, só 17 faculdades não conseguiram o credenciamento, sendo todas elas faculdades particulares.
} 
(...) não vale a pena se preparar para entrar no sistema municipal quando os benefícios salariais e de trajetória são piores que em outras instituições (...) além do que trabalhar com setores pobres exige maior esforço e dedicação que normalmente não são valorizados. ${ }^{20}$

Além da formação incompleta de alguns professores, a rotação evidenciou a pouca motivação dos profissionais na Educação Infantil municipal. As mudanças para melhorar essa situação só apareceram a partir de 2013, período que se descreverá a seguir.

\subsubsection{Século XXI: A Era do Estado Vigilante (2006 - 2014)}

Ao assumir a Presidência da República, em 2006, Michelle Bachelet define, pela primeira vez na história do Chile, a educação e o cuidado de todas as crianças menores de seis anos como tema prioritário na agenda pública e como parte das cem primeiras ações do governo. A Educação Infantil foi um dos eixos centrais da campanha eleitoral e permaneceu durante todo o seu mandato: "Cem vezes o digo e cem vezes o direi: a luta mais importante contra a desigualdade se faz na primeira infância!"21.

Coerente com esse discurso, o Estado reconheceu que as medidas do período anterior não foram suficientes para garantir a equidade, a qualidade da Educação Infantil e a proteção integral da infância. Como plano de trabalho, foi formado o Conselho Assessor Presidencial responsável por:

\footnotetext{
Elaborar um diagnóstico da situação atual e das insuficiências existentes em matéria de proteção à Infância (...) para depois formular e propor um conjunto de políticas e medidas idôneas com efeitos de implementar um sistema nacional de proteção integral da Infância. (Art.3, Decreto Supremo ${ }^{\circ}$ 072, 4 de abril de 2006, Santiago de Chile - tradução e parênteses meus.)
}

Como resultado, o Conselho constatou as irregularidades e as desigualdades na implementação de políticas públicas dedicadas à infância, entre elas as de Educação Infantil que se referiam à estrutura organizacional, ao financiamento e ao referencial curricular, assim como os vazios e as pendências com outras áreas envolvidas, como a formação profissional e a qualidade. Na busca de reivindicações, o Conselho propôs, em 2006, a criação do Sistema de Protección Integral a la Infancia: Chile Crece Contigo (ChCC), subordinado ao Ministério de Planejamento e definido como

\footnotetext{
${ }^{20}$ MONJE et al. (2007) La Acción Educativa en Educación Parvularia: Una Mirada Etnográfica, anexos p.33

${ }^{21}$ BACHELET, M. Rendição pública anual, maio de 2006 - tradução minha.
} 
Uma política pública compreensiva, intersetorial e de múltiplos componentes, um complexo sistema de intervenções de caráter integrado para oferecer proteção e assistência de acordo com as características e necessidades particulares de cada criança e sua família, pondo a disposição dessas crianças um conjunto de serviços de apoio, benefícios universais e específicos. (Gobierno de Chile, 2006, p.12 - tradução minha)

No relatório, foi justificado o grande investimento do ChCC porque:

- As crianças têm direitos: Sustentado na CDC, o Estado assume o compromisso de garantia a partir do princípio da igualdade sem distinção e independente de qualquer caraterística pessoal ou familiar das crianças. Desse direito deriva o princípio de universalidade e a integralidade de políticas, com fortes implicâncias para a ação pública, manifestadas na necessidade de que existem sistemas integrais de serviços e prestações para as crianças que se adaptem flexivelmente a suas necessidades (...)

- Porque, na primeira infância, há grandes oportunidades (e riscos) para o desenvolvimento humano: Fundamentado por teorias biológicas e cognitivas como o período mais significativo na formação do ser humano, os primeiros anos de vida são um período crítico para o desenvolvimento integral. A influência do médio ambiente durante esse período é, portanto, substancial para a formação da personalidade e das funções cerebrais superiores. Se as crianças não contam com famílias, comunidades e equipes de saúde, e educação informados e estimulantes, não apenas perdem oportunidades de desenvolvimento como não arriscam danos permanentes no futuro (...)

- Porque todas as crianças devem ter iguais oportunidades de desenvolvimento: A necessidade de avançar para uma maior equidade de oportunidades é um eixo transversal instalado no Chile. Não é aceitável, portanto, que a posição na escala de estratificação econômica em que uma pessoa nasceu seja um indicador do lugar que ocupará na vida adulta. A ideia é trabalhar conjuntamente para combater a reprodução intergeracional da pobreza (...)

- Porque o investimento no desenvolvimento infantil é estratégico para o país: $\mathrm{O}$ crescimento econômico e social dos países depende dos processos nacionais da melhoria da educação e competências da população. Nos adultos, essa tarefa não é fácil e, nesse sentido, a evidência internacional é determinante: o impacto dos programas de apoio às competências e às capacidades das pessoas depende crucialmente de que tão cedo sejam aplicados (...)

- Porque as políticas para a infância devem ser eficientes e eficazes: Fundamentada solidamente na teoria e na prática modernas da gestão pública. Na medida em que o objetivo superior da política da infância, é o desenvolvimento integral, todos os serviços, programas e prestações que a compõem devem organizar-se na forma de um sistema coerente e integrado que oriente flexível e pertinente sua gestão às metas. Isso requer uma correta definição das funções e das relações institucionais, reguladas por instrumentos que assegurem desempenho; que os cidadãos sejam atendidos em função de suas características e necessidades; que se assinem responsabilidades aos distintos níveis de gestão; e que a gestão financeira possa se organizar em torno dos resultados (...). (Ibidem, p.15-17 parênteses e tradução meus.)

Orientada pelos principios recém referidos, a política do Chile Crece Contigo, cuja lei $\mathrm{n}^{\mathrm{o}} 20.379$ foi promulgada em 12 de setembro de 2009, estava dirigida a todas as crianças e suas famílias, desde a gestação até os 6 anos de idade, e oferecia intervenções baseadas nas dinâmicas de gestão em rede, nas quais a função concreta do Estado é fiscalizar todos os 
agentes envolvidos no tratamento da infância a partir de diferentes temáticas -saúde, educação, justiça, mulher, etnia, entre outras - além de possibilitar a sua conexão através de programas intersetoriais.

A Educação Infantil representou um nicho importante para a execução dos objetivos do ChCC, principalmente orientados pela ideia de educação como oportunidade de investimento na formação de capital humano. Para tais fins, em 2010, o ChCC permitiu ainda a entrega de mais fundos fiscais e quintuplicou o número de creches públicas - pertencentes à JUNJI, à INTEGRA e aos municípios -, enquanto que as pré-escolas aumentaram de 781 a 4300. Até o ano 2010, foram ainda incorporadas mais de 85 mil novas crianças dos dois quintis mais pobres (40\%), chegando a $85 \%$ das crianças de 4 anos e mais de $90 \%$ das crianças de 5 anos matriculadas no sistema (ECONOMIST INTELLIGENCE UNIT, 2012), e havia expectativas de que esses números aumentassem nos governos seguintes.

Neste contexto, é importante resgatar que as primeiras medidas do ChCC se concentraram novamente na ampliação da cobertura, especialmente para cobrir a demanda de instituições onde a oferta não era suficiente, e na efetividade do trabalho intersetorial de "absorção" de novas politicas sociais, ora, intersetoriais, pelo sistema educacional. Três exemplos claros:

i) A integração de programas sociais de acompanhamento das crianças desde a gestação até o seu ingresso à educação fundamental, como responsabilidade do setor de saúde e educação, em rede. Destacam-se o programa de estímulo e aproximação à leitura Nacidos para leer, e o programa de promoção do aleitamento materno e vínculo mãe-filho Creciendo Juntos aplicado nos postos de saúde pública por enfermeiras e educadoras a mulheres grávidas e bebês, e continuado por educadoras em creches e pré-escolas através de um "caderno de acompanhamento", a ser preenchido pelos profissionais e pelas famílias ao longo dos primeiros anos da criança;

ii) A sanção da Lei de Subvención Preferencial (SEP) em 2008, que entrega um valor adicional de subvenção aos alunos prioritários - os mais vulneráveis - de todos os níveis de educação em todas as suas instituições. Essa lei também contribuiu para que a Educação Infantil, em 2009, fosse o nível com maior valor por aluno ${ }^{22}$, além de introduzir sistemas de prestação de contas trimestral por parte das redes financiadoras;

\footnotetext{
${ }^{22}$ CLP\$21.262 vs CLP $\$ 7.138$ por aluno de ensino médio.
} 
iii) O programa Plan de Apoyo Compartido ${ }^{23}$ instaurado no segundo ciclo (pré-escola) de EI pública com dependência municipal e particular subvencionada e articulado com os posteriores níveis de ensino. Esse programa consistiu em entregar "manuais de atividades" a famílias e a professores para incrementar as aprendizagens das crianças em casa e na escola, os quais deveriam ser avaliados a cada três meses pelo professor e inseridos em plataforma online, que calculava o rendimento geral da turma, identificando caso a caso - a partir das três cores do semáforo - os aprendizados consolidados e os que ainda precisavam de reforço, além de ter um panorama dos resultados de todas as instituições dependentes do município. Este último programa atualmente, em alguns municípios, encontra-se descontinuado.

De acordo com Alderstein (2010), a política do ChCC depositou a sua eficácia a partir da causalidade: mais centros educativos e mais crianças neles, mais possibilidades de controlar as variáveis estruturais e, dessa maneira, assegurar processos de qualidade, estes últimos como resultado. A concepção de qualidade educativa foi decorrendo “(...) por uma ideologia que dá importância indevida aos mecanismos de mercado para melhorar o ensino e aprendizagem" (OCDE, 2004, p.290 - tradução minha). As reformulações nas políticas públicas em Educação Infantil estavam sendo orientadas para conseguir um melhor desempenho das redes JUNJI, INTEGRA, municípios e mantenedores particulares, o que fazia presumir que o destaque não estava no que o Estado entregava a esses agentes, mas no que eles entregavam ao Estado.

As novas orientações, baseadas na "prestação de contas", evidenciaram as limitações das políticas de EI e colocaram em "xeque" os verdadeiros sentidos da ação local como fator de qualidade. A participação dos centros de atendimento de JUNJI e INTEGRA, municípios e mantenedores particulares continuou se circunscrevendo a práticas descontextualizadas. A dívida do período anterior ainda se encontrava latente.

Concomitante à instalação da política do ChCC, a totalidade do sistema educativo chileno ganhava destaque dentro da opinião cidadã. A privatização e a concorrência foram estratégias de mercado para converter a educação em um negócio enormemente lucrativo. Dentro da lógica que legitimava esse tipo de educação como parte da educação pública, parecia que também se legitimava a existência de "creches e pré-escolas públicas para pobres" e "creches e pré-escolas públicas para não tão pobres", de maneira que a integração das experiências educativas era praticamente inexistente. Por outro lado, a forma como o binômio centralização-descentralização se instaurou como modelo de gestão priorizou

\footnotetext{
${ }^{23}$ Os nomes dos programas referidos podem traduzir-se como Nascidos para ler, Crescendo Juntos e Plano de Apoio Partilhado.
} 
mecanismos gerenciais na busca de melhorias e ignorou as contribuições das práticas democráticas. Desde 2000, a maioria das reformas aplicadas centralizou métodos de trabalho e aspectos pedagógicos pelos quais MINEDUC e JUNJI "dirigiram" a educação a distância mediante um processo fundamentalmente econométrico (injetar recursos e avaliar resultados), o que não se articulou com as atribuições "descentralizadas" dos municípios e mantenedores. Os centros de EI tornaram-se apenas executores de um projeto pedagógico nacional definido e avaliado externamente, cujos efeitos inibiram a autonomia institucional e a inovação educativa das localidades.

Variados grupos da sociedade concordavam que o estilo dessa gestão educativa, que predominou e foi amadurecendo no Chile desde 1990, parecia ter chegado a um "teto estrutural", pois a segregação constante só podia ser combatida com a transformação dos grandes pilares do sistema: os modelos de financiamento e gestão da educação pública (CORNEJO, 2006). Essa discussão alcançou seu ponto máximo de emergência nas mobilizações dos estudantes do ensino médio ${ }^{24}$ surgidas no ano de 2006 e prolongadas por quase dois anos. O movimento, nomeado "dos Pinguins", envolveu também estudantes dos últimos anos de ensino fundamental, universitários, grêmios docentes e famílias, num processo de reflexão crítica sobre a educação do país. Formou-se o Bloque Social por la Educación $^{25}$, que elaborou um relatório detalhando as falhas do sistema educativo em vigor as quais têm sido discutidas ao longo deste capítulo - e apresentou uma proposta na qual a sociedade fosse participante ativa nas decisões relacionadas com as políticas públicas de educação do país.

Cabe ressaltar que o documento foi planejado e guiado maioritariamente pelos estudantes, oficializado no ano de 2007, e apresentado ao Conselho Presidencial. No documento, ressalta-se que os extraordinários avanços em cobertura e gasto público da educação chilena permitem focar a atenção em mudanças de "segunda geração", isto é, centrar a preocupação em que os recursos públicos investidos sejam dirigidos às necessidades locais. Sugeriu-se ampliar a discussão sobre o real significado de educação de qualidade em cada nível de ensino e conduzir adequadamente as políticas subsequentes.

\footnotetext{
24 A chamada "Revolta dos Pinguins", foi um movimento que reuniu gradualmente milhões de estudantes secundários de todo o país, os quais se negaram a entrar nas escolas públicas e protestaram nas ruas para exigir compromissos de curto prazo e sobretudo demandar mudanças estruturais do sistema educativo do país desde suas bases.

${ }^{25}$ Constituído por representantes dos estudantes secundários, universitários, co-docentes, professores, pais e apoderados, com suas respectivas instituições (ANES; CONFECH; CONFESUP, Colégio de Professores e Associação de Pais e Apoderados).
} 
Assim, foram propostas demandas principais de melhoria. Aqui as três que atingem à EI:

a) Mudança na Constituição Política e Marco Regulatório: Foi exigida uma mudança na Constituição Política de 1980 e no papel do Estado, que deveria deixar de ser concebido apenas como subsidiário e gerencial. Isso implicou também em modificar a LOCE que, através da imposição do conceito de liberdade do ensino - que discriminou e sobrevalorizou o lucro -, limitou as faculdades das esferas governamentais para assegurar o direito educativo. Além disso, propôs-se a explicitação do desenvolvimento de educação descentralizada através da gestão local e democrática articulada com o Estado, o fundamental envolvimento das experiências práticas, o fortalecimento da organização e a participação dos atores educativos (professores, estudantes e famílias) como condições fundamentais para os processos de melhoria.

b) Nova estrutura do atendimento da Educação Infantil: Considerou-se que os objetivos e critérios para enfrentar o desafio de transformação do sistema educativo chileno exigem esforços importantes dos diferentes níveis de gestão, a real integração das instituições e/ou a redefinição de algumas funções dos organismos já existentes para reforçar a ação educativa tanto no nível nacional como no local.

O MINEDUC assumiria condução, direção, orientação, desenho e planejamento estratégico da política educativa nacional(...)

A Superintendência de Educação, por sua parte, seria o organismo estatal encarregado de garantir a educação como direito e não para vigiar o mercado educativo (...). Assumiria a função de inspeção e avaliação de todos os estabelecimentos segundo os critérios de seleção e não de lucro $O$ Conselho Nacional de Educação reforçaria a linha de participação da comunidade nacional (junto com os Conselhos territoriais). Integrado por representantes do MINEDUC, universidades, professorado, pais e famílias, alunos e atores relevantes do mundo educativo. Será assessor direto do Ministro de modo a solucionar as questões determinadas por este.

Em nível local, a Secretaria Regional Ministerial (SEREMI) seria a máxima autoridade educativa nas regiões e sua função seria programar as políticas públicas nacionais, assumindo a responsabilidade de que estas sejam pertinentes, permitindo adaptá-la se for preciso.

A escola perfila-se como o lugar propício de ajuste das políticas nacionais e regionais, planteia-se a criação dos "Serviços Públicos de Educação", entidades estatais presentes em casa cidade com o objetivo de complementar as ações do estabelecimento (...) a instalação dessas instituições retira a responsabilidade administrativa dos municípios sem significar a perda da identidade local já que os serviços estariam contidos nos projetos educativos dos centros junto com os outros agentes. (La Crisis Educativa en Chile. Diagnóstico y Propuestas, Bloque Social, 2006, p.5 - tradução e grifos meus)

c) Financiamento: No documento, pode-se encontrar uma clara tendência para redefinir o 
financiamento da educação chilena, extinguindo a existência da subvenção por aluno e, por consequência, dos estabelecimentos dependentes de mantenedores particulares, passando essas escolas a terem administração completa do Estado através do município.

O financiamento deve garantir nos estabelecimentos públicos e particulares subvencionados a possibilidade de usar incentivos que motivem melhorias na qualidade educativa de acordo com as realidades culturais de cada estabelecimento, a partir de um piso suficiente de investimento que não seja relacionado a subvenção por aluno. Esta última só tem sentido como incentivo complementar além do piso de mínimo, para garantir educação integral, como mostram algumas experiências internacionais bem-sucedidas. (Ibidem, p.6)

O documento adverte a importância da participação ativa do município na educação local e considera fundamental fortalecer suas equipes técnico-pedagógicas em todos os níveis para garantir a correta adaptação das políticas nacionais e colaborar junto aos estabelecimentos educativos nos processos de democratização para "assim construir um sistema mais efetivo, integral e justo" (Ibidem, p.12).

O movimento estudantil capturou as críticas sobre a educação chilena, entendida e legitimada até então como direito individual vinculado a receber um "serviço" de qualidade. Não obstante, frente à configuração do Estado "super vigilante" da época, nutrido por teorias de prestação de contas e gestão orientadas a resultados, a única solução possível oferecida para influenciar o término das greves, foi a promulgação do projeto de lei que substitui a LOCE. Em 2009, a LOCE foi sucedida pela Ley General de Educación (LGE), que integrou algumas demandas dos estudantes relacionadas à nova estrutura e ao novo financiamento, mas não esclareceu o intuito de promoção de autonomia e de participação dos municípios e centros educativos.

Como complemento, em 2011, foi sancionada a Ley del Sistema Nacional de Aseguramiento de la Calidad de la Educación Parvularia, Básica y Media ( $n^{\circ}$ 20.529/2011) e cria-se a Superintendencia e Agencia de Calidad. Embora esta lei inclua os três níveis de ensino, a proposta inicial não tem especificadas, até hoje, as definições e as formas de qualificação da Educação Infantil.

As ambiguidades registradas nessas últimas duas leis colaboraram ainda para o aumento das mobilizações estudantis e das exigências em torno a uma mudança efetiva. Já em 2013, no governo de Sebastian Piñera, foi aprovado o Proyecto de Fortalecimento da Educação Pública, que modifica os padrões de mercado instalados e estabelece o Proyecto de Carrera Docente, que inclui os professores de Educação Infantil em todas as medidas de formação inicial e continuada dos profissionais do setor público. As iniciativas legislativas referentes à 
Educação Infantil foram aprovadas em 2014, no segundo governo de Michelle Bachelet:

- Primeira iniciativa legislativa: Nova institucionalização da Educação Infantil
Chilena. Criada a Subsecretaria Ministerial de Educação Infantil e a Intendência de
Educação Infantil, com sedes em todas as regiôes, que será o encarregado da
integração, promoção, desenvolvimento e coordenação de Educação Infantil de
qualidade para todas as crianças de 0 a 6 anos. (Art.1)
- Segunda inciativa legislativa: Regularizar a admissão e o acesso de todas as
crianças nas instituições educativas. Eliminar-se-á o pagamento das famílias por
educação pública e proibir-se-á o lucro dos estabelecimentos que recebam
financiamento direto do Estado. (La Reforma Educacional, Primeras Iniciativas
Legislativas, Apresentação do Ministro de Educação Nicolas Eyzaguirre, Chile 2014
- tradução minha)

De acordo com a correção feita pelo sindicato de educadores infantis, a nova institucionalização da educação pretende acabar com a divisão entre creche e pré-escola e por tanto, instaura-se um único organismo que desenhe, coordene, administre e avalie as políticas públicas para toda a EI de 0 a 6 anos sem a duplicidade de funções e atribuições existentes para JUNJI e MINEDUC. Por outro lado, o fato de esta organização estar presente em cada região do país, permite incorporar uma maior participação dos municípios na tomada de decisões e reivindicar a ação local como eixo de qualificação da EI.

O governo declarou, na conta pública nacional do ano 2015, o seu compromisso com a Educação Infantil como direito social e direito educativo da criança, considerando-o não lucrativo, democrático e essencial para o desenvolvimento, sustentado na não discriminação, não escolarização e não padronização do ensino e dos processos de aprendizagem. Paralelo a isso, é sancionada a Ley de Inclusión (2015), que põe fim às instituições particulares subvencionadas, portanto, creches VTF e pré-escolas com estas características; proíbe a seleção de alunos e permite a criação de projetos educativos próprios nas escolas, pré-escolas e creches públicas. Em 2015, 345 instituições particulares subvencionadas deixaram de depender de mantenedores particulares e passaram a depender diretamente da administração do município. Além disto, entraram em funcionamento as supracitadas subsecretarias e Intendências de Educação Infantil com objetivo de integrar efetivamente ambos os ciclos e realizar o trabalho conjunto com os municípios e os centros a partir da criação de Conselhos Escolares.

Ao longo desta seção, registrou-se como a configuração de políticas públicas em Educação Infantil no Chile foi construída a partir de variados acontecimentos políticos, econômicos e sociais, constituindo um processo dinâmico de reformulações que, em conjunto, significaram importantes avanços por um lado, e, por outro, a sistematização e a consolidação 
de um cenário rígido e com espaço limitado para a participação e a autonomia das esferas locais de educação.

2.2.4 Estatísticas e conclusões preliminares

Gráfico 3 - Evolução da taxa de cobertura nacional de EI por faixa etária em Chile (\%) 1990-2013

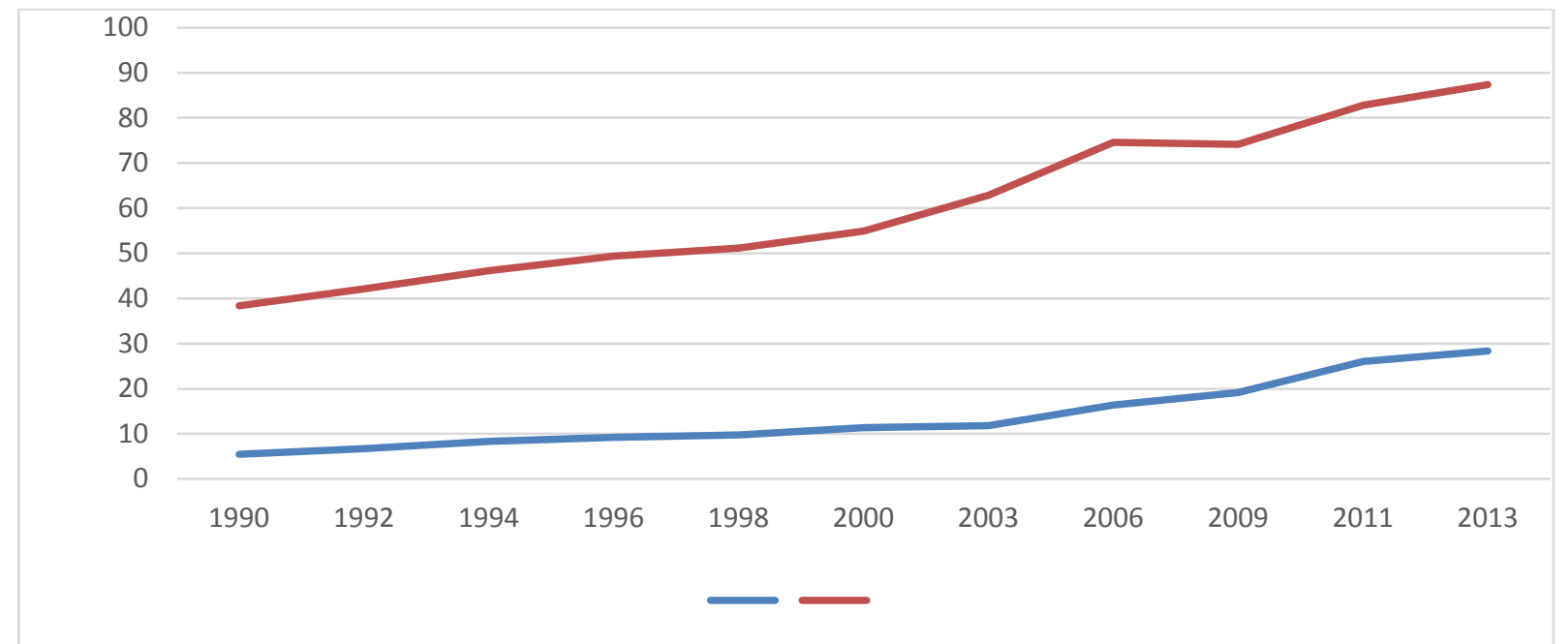

Fonte: Elaboração própria baseada na informação da frequência de crianças em instituições de EI do Ministério de Desenvolvimento Social, Encuesta CASEN (Pesquisa de Caracterização Socioeconômica Nacional), anos respectivos. Se integram instituições das redes JUNJI, INTEGRA, municípios, particulares subvencionados e creches VTF).

\section{Gráfico 4- Evolução da cobertura nacional de EI por quintil de ingresso autônomo em Chile (\%) 1990-2011}

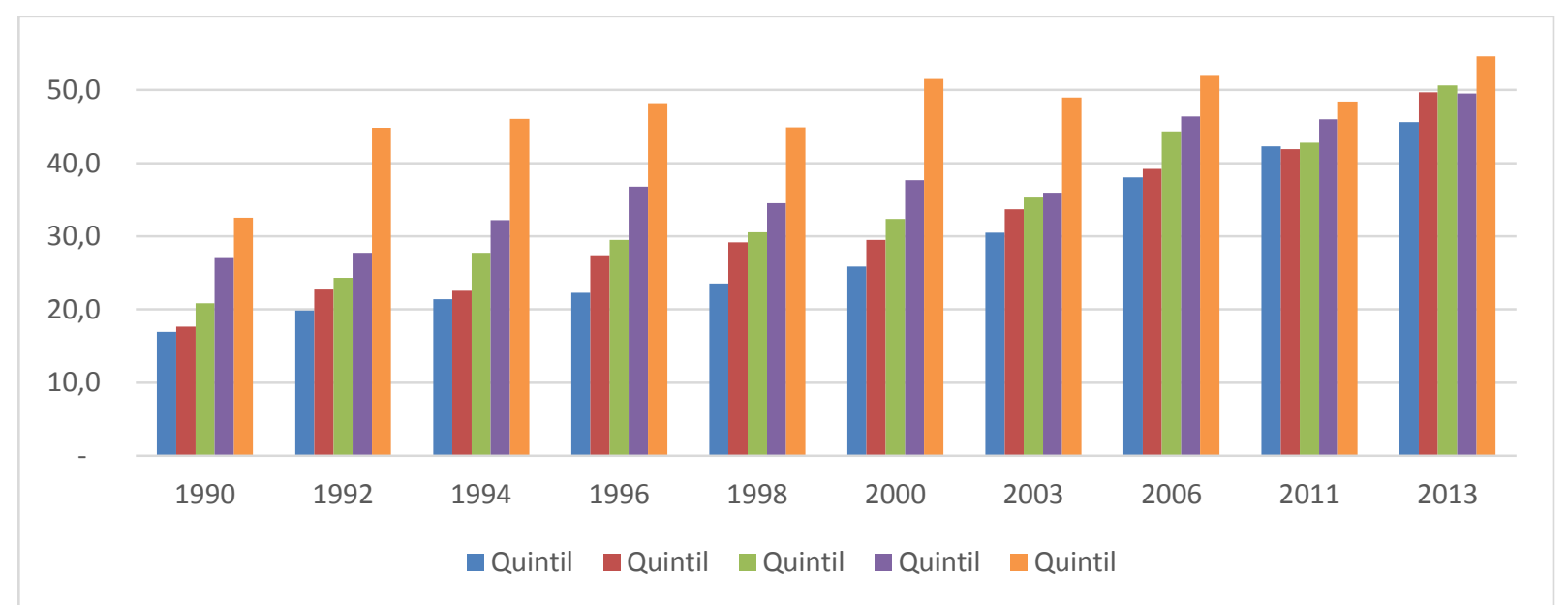

Fonte: Elaboração própria baseada na informação do Ministério de Desenvolvimento Social (Chile) e do arquivo histórico CASEN, anos respectivos. 
Tabela 5- Evolução da cobertura nacional de EI por região em Chile (\%) 1990-2011

\begin{tabular}{|c|c|c|c|c|c|c|c|c|c|c|c|c|c|c|}
\hline $\begin{array}{c}\text { Regi } \\
\text { ão }\end{array}$ & I & II & III & IV & V & VI & VII & VIII & IX & X & XI & XII & RM & Total \\
\hline $\mathbf{1 9 9 0}$ & 30,9 & 19,0 & 24,5 & 18,4 & 20,2 & 18,1 & 16,5 & 17,3 & 15,0 & 14,5 & 17,5 & 23,1 & 25,3 & 21,0 \\
\hline $\mathbf{1 9 9 2}$ & 33,0 & 23,4 & 27,7 & 23,7 & 25,5 & 20,7 & 18,2 & 21,8 & 21,3 & 18,8 & 18,3 & 25,3 & 29,1 & 25,0 \\
\hline $\mathbf{1 9 9 4}$ & 32,3 & 31,3 & 29,1 & 30,4 & 30,1 & 23,9 & 23,9 & 23,7 & 15,6 & 18,1 & 24,2 & 29,8 & 30,5 & 27,1 \\
\hline $\mathbf{1 9 9 6}$ & 35,7 & 27,9 & 24,6 & 35,4 & 32,3 & 24,7 & 26,4 & 28,2 & 24,0 & 21,3 & 25,7 & 41,6 & 32,7 & 29,9 \\
\hline $\mathbf{1 9 9 8}$ & 32,5 & 31,8 & 32,9 & 33,0 & 32,9 & 25,0 & 29,9 & 27,0 & 24,0 & 23,0 & 36,8 & 34,9 & 32,6 & 30,3 \\
\hline $\mathbf{2 0 0 0}$ & 34,6 & 36,7 & 39,7 & 36,4 & 33,8 & 29,9 & 29,2 & 28,7 & 26,6 & 25,2 & 39,0 & 39,5 & 35,1 & 32,7 \\
\hline $\mathbf{2 0 0 3}$ & 35,2 & 30,2 & 38,3 & 36,5 & 35,0 & 34,6 & 34,0 & 33,2 & 32,4 & 34,3 & 48,6 & 45,0 & 36,1 & 35,1 \\
\hline $\mathbf{2 0 0 6}$ & 47,8 & 39,9 & 42,5 & 47,2 & 42,4 & 40,2 & 42,5 & 38,9 & 38,1 & 36,5 & 49,4 & 50,0 & 44,0 & 42,4 \\
\hline $\mathbf{2 0 1 1}$ & 47,5 & 38,1 & 38,1 & 47,4 & 50,2 & 41,9 & 43,4 & 40,8 & 45,5 & 40,4 & 52,3 & 51,2 & 43,1 & 43,5 \\
\hline
\end{tabular}

Fonte: Elaboração própria baseada na informação do Ministério de Desenvolvimento Social (Chile) e do arquivo histórico CASEN, anos respectivos.

Gráfico 6 - Evolução do número de matrículas na pré-escola segundo dependência administrativa em Chile - 1990-2013

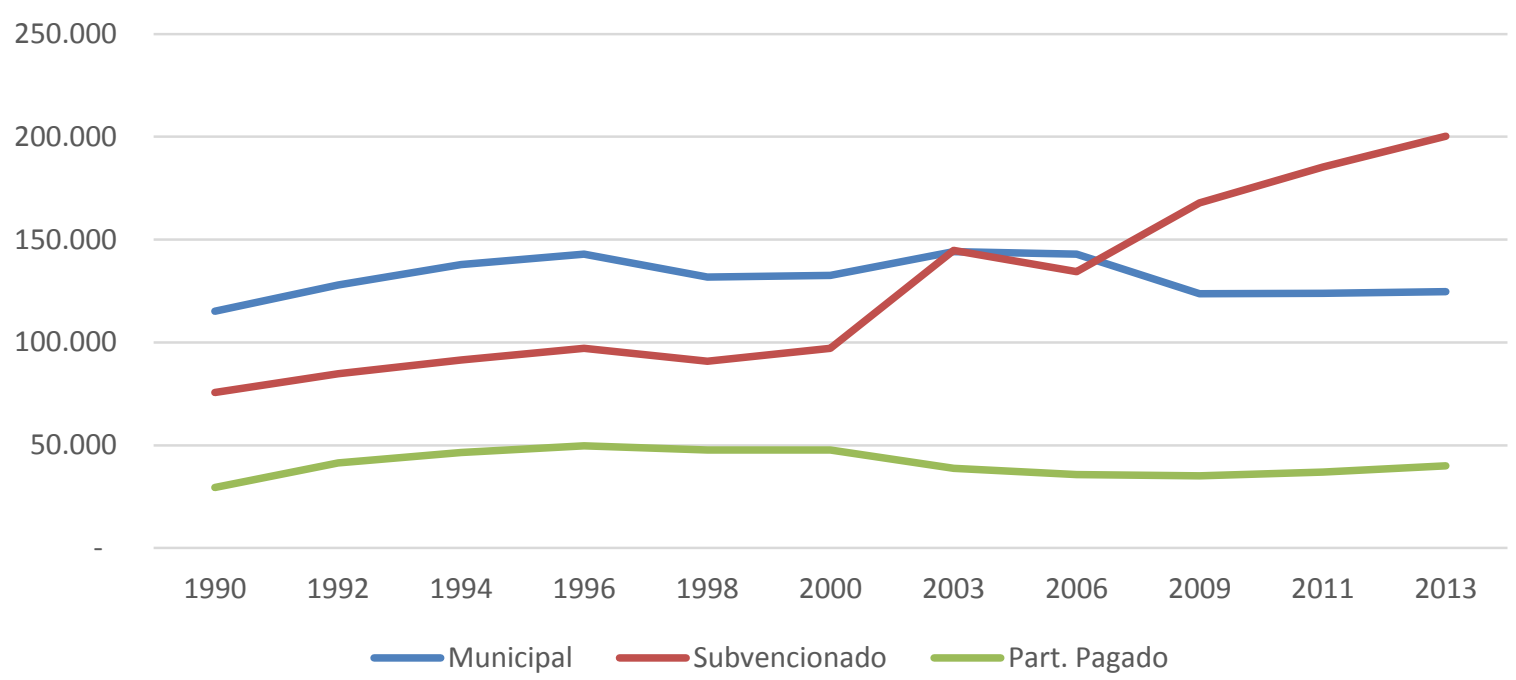

Fonte: Elaboração própria baseada na informação do Ministério de Desenvolvimento Social, Encuesta CASEN (Pesquisa de Caracterização Socioeconômica Nacional), anos respectivos. Considera-se apenas a informação de matrículas dos níveis de pré-escola. 


\section{Gráfico 7- Evolução do gasto público nacional em EI em Chile 1990-2013 (por milhões de pesos)}

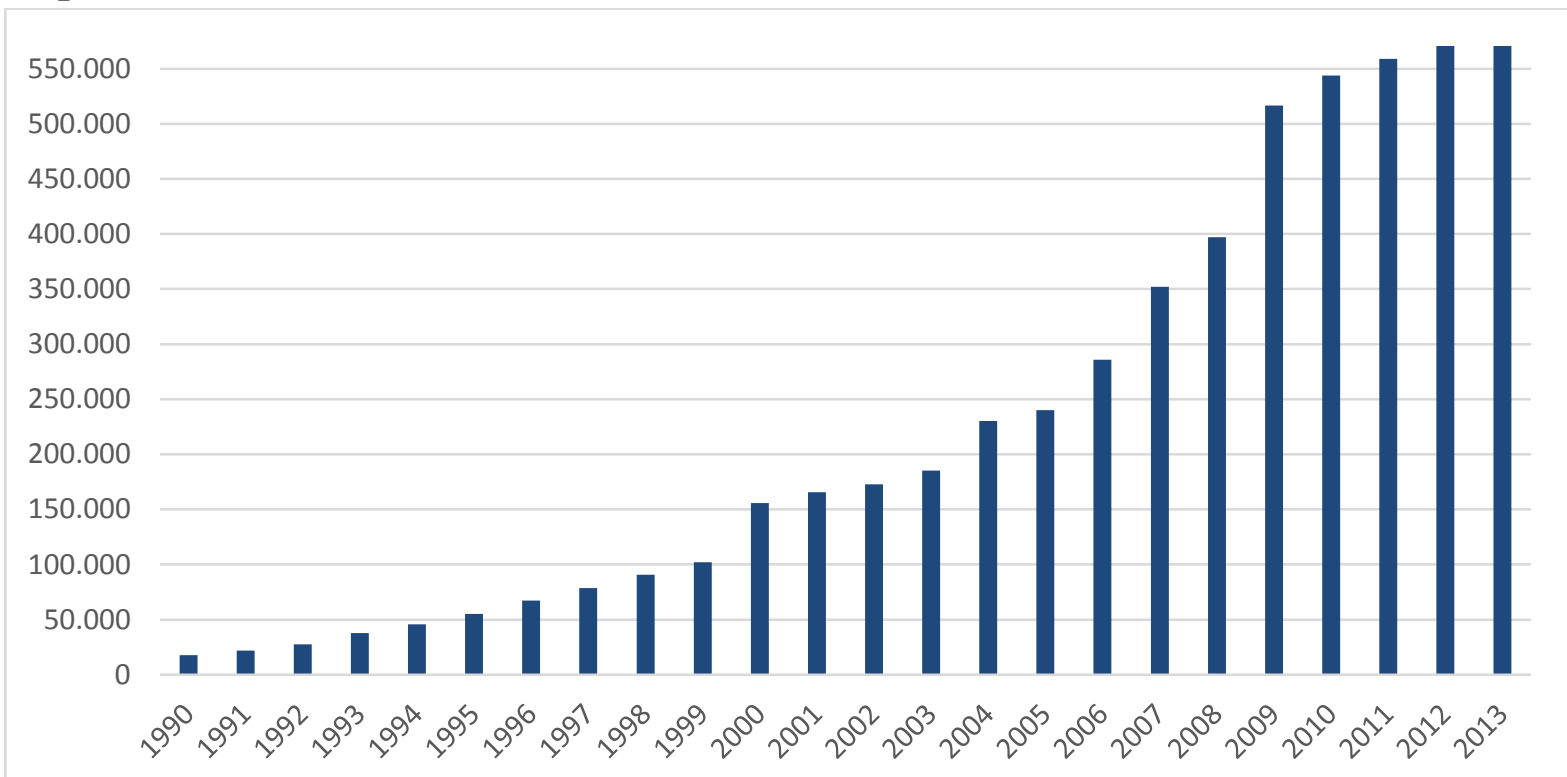

Fonte: Elaboração própria a partir dos estados da gestão financeira do setor público. Controladoria Geral da República. Balanços fiscais. Departamento Recursos Financeiros, MINEDUC. Estatísticas, matrícula e gasto em subvenções por nível, MINEDUC. IPC, INE. Tipo de câmbio: observada média anual, Banco Central.

Notas: O gasto público inclui JUNJI, MINEDUC e INTEGRA. Inclui também gasto do MINEDUC executado, recursos municipais para operação e investimento, além do investimento educacional realizado pelo Ministério da Fazenda do FNDR (Fundo Nacional de Desenvolvimento Regional) e pelo Fundo Social. Os gastos incluem administração. Não incluem educação particular privada.

A partir do entendimento do caso chileno e das informações estatísticas do período, é possível concluir que:

a) As políticas de organização estrutural e de financiamento apoiaram o incremento da cobertura nacional de Educação Infantil significativamente entre os anos 1990 e 2013, principalmente na pré-escola (4 a 5 anos), sancionada como obrigatória em 2009. O primeiro ciclo (0 a 3 anos) ainda se encontra em fase de expansão, longe de atingir a totalidade das crianças dessa idade, porém, as últimas pesquisas do MINEDUC e do Ministério do Desenvolvimento registram que a não assistência de crianças pequenas aos centros de atendimento não se deve especificamente à falta de vagas, se não pela interseção de outras variáveis relacionadas à percepção e à valoração que as famílias chilenas ainda têm acerca da EI de crianças pequenas ${ }^{26}$.

\footnotetext{
${ }^{26}$ Segundo as pesquisas CASEN 2008, 2009, 2010, 2011 e 2012, entre as principais razões dadas pelas famílias para não matricularem seus filhos na creche se encontram: "Não é preciso porque cuidamos deles em casa" (75\% no último censo); "Não me parece necessário que cuidem de uma criança dessa idade" (10,1 \% no último censo); "Desconfio do cuidado que receberia meu filho" (6,8 \%); "Meu filho fica doente rapidamente" (3,8\%). A razão econômica ou falta de acesso registra apenas um 1,8\% em 2008 e 0,3\% em 2013.
} 
b) O aumento da cobertura da EI nos quintis mais pobres da população (I, II e III) registra também um incremento positivo. Isso pela injeção de maior gasto público nesta etapa educativa, ligado ao conjunto de políticas sociais e programas alternativos de baixo custo para o atendimento das necessidades básicas, como alimentação, saúde, materiais de estudo, etc. As políticas sociais integradas ao sistema educativo como parte do intuito de expansão, tem assegurado o patamar mínimo de equidade nas condições de acesso e permanência das crianças na EI pública, mas não tem sido suficiente para garantir a redução das desigualdades educativas em torno à qualidade do atendimento.

c) O gráfico da evolução do número de matrículas da pré-escola, segundo dependência administrativa, evidencia a concorrência entre as instituições municipais e particulares subvencionadas que predominou nos três períodos descritos. Mostra-se como o sistema misto de estrutura e financiamento foi captando alunos que "migraram" desde centros municipais de atenção e como o município foi perdendo matrículas, e, com elas, subvenções e recursos econômicos, ficando paradoxalmente com menos verba fiscal para atender aos estudantes mais vulneráveis.

d) No que tange à organização do Estado nacional em torno das políticas de EI, no Chile foram identificadas três fases caracterizadas pelo trânsito do papel do Estado desde uma função tipicamente reducionista, logo compensatória, até se configurar como “vigilante". Nesse sentido, é importante concluir que nos três períodos registrados, o Estado chileno nunca diminuiu seu poder, senão que apenas mudou os modos de exercê-lo "a distância", sustentando assim os princípios de mercado, centralização do poder público e gestão gerencial dominantes e presentes nas bases legislativas dos períodos descritos.

e) As políticas de estrutura, financiamento, currículo e formação docente em EI utilizaram o subterfúgio retórico de descentralização, participação e responsabilização dos municípios, redes educativas e instituições para apenas introduzir mecanismos de avaliação institucional a partir de objetivos definidos externamente como garantia de educação de qualidade e direitos educativos da criança, sem considerar a participação da criança e o seu entorno educativo próximo. Nesse panorama, o município foi configurando-se como esfera responsável por um bom desempenho, embora executor de políticas descontextualizadas, sem poder de mudança, contextualização nem construção. 
f) A qualidade da EI foi construída na sua compatibilidade entre o modelo de gestão baseado em resultados e os objetivos de formação de capital humano, dois paradigmas internacionais que influenciaram enormemente os processos econômicos e de proteção social do país. Porém, a implementação no setor educativo apenas orientada por racionalidades econômicas e de eficácia não reduziu as desigualdades educativas e, em alguns casos, principalmente em EI, manteve os índices de segregação social.

g) Frente à pressão exercida por grupos da população de assumir novos desafios de participação e gestão democrática pelas esferas subnacionais, o Estado, desde 2012, novamente está ajustando as políticas e reforçando a inclusão de novos elementos de gestão democrática e autonomia local, um processo talvez ainda mais complexo de se efetivar, principalmente dentro de um sistema tão vertical e sistematizado. Espera-se, então, que as novas reformulações sigam além das conquistas legais e sejam consolidadas como formas democráticas de construção educativa local, que considerem as potencialidades do município e envolvam gestores, professores, coordenadores pedagógicos, famílias e crianças na configuração do contexto como fator de qualidade da Educação Infantil.

\section{$2.3 O$ contexto brasileiro}

Esta seção detalha a configuração das políticas públicas de Educação Infantil brasileira contemporânea, com especial atenção a partir da Constituição Federal de 1988. Tal como foi registrado no Chile, entende-se que, no Brasil, a Educação Infantil, assim como a preocupação da sociedade pelas suas crianças, tem sido um resultado de dinâmicas políticas, econômicas e sociais que datam do início do século XX, porém, a aproximação e a descrição do cenário brasileiro realiza-se da mesma forma, através de três momentos destacados na organização do Estado federativo desde as últimas décadas do século XX até a atualidade, salientando as principais fontes legislativas e as políticas públicas assim como as mudanças na concepção de Educação Infantil e seus sistemas de gestão. Aliás, será apresentado também um quarto ponto com as principais estatísticas educacionais e conclusões preliminares. 


\subsubsection{O regime militar e a posterior abertura democrática da EI (1964-1994)}

Segundo Andrade (2010, p. 141), o regime autoritário instaurado com o golpe militar em $1964^{27}$ e o agravamento das condições de vida da maioria da população brasileira ocasionaram ações paliativas e reguladoras no âmbito social, acarretando profundas mudanças na ação governamental destinada à infância no país. As creches, especialmente, foram conformadas em consonância com as necessidades da classe trabalhadora, necessário diante das questões emergidas pelo empobrecimento das condições de vida da população e a crescente demanda por serviços de consumo coletivo, como transporte, saúde, escolas, creches e outros. O sistema econômico adotado no Brasil, com marcadas características de capitalismo dependente e concentrador de riquezas, impediu que a maioria da população tivesse satisfatórias condições de vida. O baixo salário e a falta de extensão de serviços para atender as necessidades sociais agravaram a questão da creche, que não foi mais aceita apenas como uma ajuda filantrópica ou empresarial e começou a ser reivindicada pela população mais pobre como necessidade das mães que precisam trabalhar para a subsistência da família (Oliveira, 1988, p.48).

Em 1966, no I Seminário sobre Creches no Estado de São Paulo, promovido pela Secretaria do Bem-Estar Social, o conceito de creche foi definido como: "um serviço que oferece um potencial capaz de garantir o desenvolvimento infantil, compensando as deficiências de um meio precário próprio das famílias da classe trabalhadora" (Haddad \& Oliveira, 1990, p.109). A creche foi apresentada como instituição de atenção à infância capaz de atender os filhos dos trabalhadores, contribuindo assim na promoção da família e na prevenção da marginalidade. Para um melhor entendimento da época, explorar-se-á o trabalho de Rosemberg (2003, p.25) que concebe a Educação Infantil integrada às políticas sociais como um subsetor das políticas educacionais e de assistência ao(à) trabalhador(a), e considera os anos 1970 como um importante ponto de início para o estudo da EI contemporânea brasileira, estabelecendo períodos na configuração das políticas públicas.

Assim, no primeiro período ocorrido em ditadura, a autora estabelece que, entre o final de 1970 e 1980, ocorre a implantação de um modelo de educação de massa, alinhado aos indicativos do Fundo das Nações Unidas para a Infância - UNICEF, e da Organização das Nações Unidas para a Educação, a Ciência e a Cultura - UNESCO, para os países subdesenvolvidos, organismos estes que difundiram nestes países a ideia de uma "educação

\footnotetext{
${ }^{27}$ O início da década de 1960 no Brasil foi marcado por um momento de crise política em consonância com o contexto da Guerra Fria, que culminará com o golpe militar de 1964.
} 
pré-escolar compensatória de carências para as populações pobres e apoiadas em recursos da comunidade, visando despender poucas verbas do Estado para sua expansão" (Rosemberg, 2002, p.33). Em outras palavras, até o final dos anos 1960 houve uma base compartilhada entre países desenvolvidos e subdesenvolvidos quanto aos modelos de instituições de Educação Infantil, seguindo os modelos das creches, principalmente destinados às crianças pobres, e os jardins de infância, para crianças mais abastadas. Entre 1970 e 1980, esse modelo é rompido, quando a Educação Infantil passa a integrar a agenda das políticas de desenvolvimento econômico e social elaboradas pelos organismos internacionais vinculados à ONU, à UNICEF e à UNESCO, e é nesse processo que, enquanto aos países ricos cabe a expansão com qualidade, aos países pobres cumpre operacionalizar a expansão a baixo custo. São destacadas as principais características do modelo de Educação Infantil para os países subdesenvolvidos, que contribuíram para a criação de programas e projetos no Brasil destinados especialmente aos mais carentes e às regiões mais empobrecidas. Dois grandes programas de âmbito federal: o Programa Casulo, administrado pela Legião Brasileira de Assistência (LBA), e o Movimento Brasileiro em Prol da Alfabetização ${ }^{28}$, ambos implementados pelo Ministério da Educação. Para a autora, os efeitos dos modelos de EI de massa "retardaram o processo de construção nacional de um modelo de Educação Infantil democrático, de qualidade, centrado na criança, isto é, em suas necessidades e cultura" (Rosemberg, 2003, p.39), e deixaram como herança dois grandes aspectos: a) o valor da EI como via para combater a pobreza, especialmente a desnutrição, e, para melhorar, o desempenho da criança no ensino fundamental, justificando, assim, a necessidade de expandir as creches e os centros de atendimento; e b) a forma de expansão da EI no Brasil, que foi realizada por meio de modelos que minimizassem investimentos públicos, marcados pela improvisação quanto a espaço físico, material pedagógico e mão de obra; a criação das creches comunitárias e municipais; a presença de profissionais leigos nas instituições de crianças com mais de 7 anos na Educação Infantil, e a consolidação de três modalidades de

\footnotetext{
${ }^{28}$ O Projeto de Creches da LBA se expandiu rapidamente. Tratava-se de um programa de âmbito nacional que, através de convênios, repassava verbas para as prefeituras ou instituições privadas; previa atendimento à população de baixa renda; jornada diária de atendimento de 4 ou 8 horas; creches instaladas em equipamentos simples, com aproveitamento de espaços ociosos da comunidade e concepção preventiva e compensatória de atendimento infantil (CAMPOS, ROSEMBERG, FERREIRA, 1995). O MOBRAL, conforme análise de Campos R. (2008), atuou de maneira rápida e barata, estabeleceu para seus profissionais um estereótipo feminino, com apelo à emotividade, à meiguice e ao amor maternal, defendia o espontaneísmo e incentivava o voluntariado, primando pela antiprofissionalização, e a função pedagógica defendida aproximava-se muito da preparatória para a escolaridade posterior. Em relação a esses dois programas federais, Rosemberg (1992, p.29) assinala que "MOBRAL e LBA parecem ter disputado a mesma clientela infantil, apoiando-se em instrumentos administrativos semelhantes - uma rede de profissionais vinculados à administração federal e o repasse de verbas através de convênios".
} 
atendimento: creches, pré-escolas e classes de alfabetização dada a prioridade de universalização do ensino fundamental. Dessa maneira, os programas denominados "não formais", "alternativos" ou "não institucionais", com discursos e práticas de atendimento às crianças nas creches influenciados pelas teorias da privação cultural e da educação compensatória, atribuíram à instituição o papel de suprir as carências de ordem física, material, social e psicológica das camadas empobrecidas: "além de ocupar o lugar da falta moral, econômica e higiênica da família, a creche também terá que dar conta da carência afetiva, social, nutricional e cognitiva da criança” (Haddad, 1991, p.114).

A partir de 1974, através da criação da Coordenação de Educação Pré-Escolar (MEC/COEPRE) e dos documentos do Conselho Federal de Educação, o plano das agendas públicas em torno da EI caracterizou-se pela superposição de responsabilidades de diversos setores: assistência, educação, saúde e trabalho. A concepção predominante na década de 1970, no âmbito das políticas educacionais destinadas às crianças de 0 a 6 anos, era a educação compensatória, objetivando a compensação de carências culturais, deficiências linguísticas e defasagens afetivas das crianças pobres. A partir da influência das agências internacionais, documentos oficiais do MEC faziam a defesa de que a pré-escola poderia, por antecipação, salvar a escola dos problemas relativos ao fracasso escolar. Essa concepção atingiu o Brasil durante o período de ditadura militar, conforme sinaliza Rosemberg (2002), encontrando as condições para sua proliferação. Parecia ser que o intuito de ampliação do acesso à Educação Infantil estava demarcado pela baixa qualidade e pelo acirramento dos processos de exclusão, daí que a criação da COEPRE e a ênfase no pré-escolar ocorrem em um contexto maioritariamente ambíguo, em que o discurso oficial apontava a educação préescolar como necessidade, mas o planejamento da União não destinava verba específica para a área, situação que se estendeu até o fim de ditadura (KRAMER, 2006).

Como segundo período, Rosemberg estabelece o fim da ditadura militar, abrangendo o final da década de 1980 até meados de 1990, quando ocorre um movimento duplo, demarcado por um lado pela expansão da Educação Infantil seguindo o modelo de baixo custo e, por outro, o incremento da consciência social da Educação Infantil como um direito das crianças pequenas à educação e um direito de assistência aos filhos de pais e mães trabalhadores (ROSEMBERG, 2002). A eclosão dos movimentos sociais no país e a intensa mobilização política em prol da abertura democrática após a ditadura foi cenário de mobilizações em torno dos direitos das crianças e dos adolescentes, com ampla participação da sociedade civil, resultando em um novo ordenamento legal e em uma nova doutrina da infância, na qual a 
criança deixa de ser vista como objeto de tutela e passa a ser considerada sujeito de direitos, incluindo o direito à Educação Infantil.

Já em 1979, na realização do I Congresso da Mulher Paulista, oficializou-se o Movimento de Luta por Creches ${ }^{29}$ integrado inicialmente por mulheres da periferia, em geral donas de casa e domésticas organizadas através do clube de mães e, posteriormente, operárias, grupos feministas e intelectuais, que aderiram ao movimento. A organização popular e incorporada aos demais movimentos em defesa da criança e do adolescente, consolidou-se, nesse momento, em um período de mudança da identidade institucional da creche, ampliando seu caráter assistencialista à dimensão educacional (ANDRADE, 2010, p.145). Destacam-se ações importantes no campo da educação pré-escolar do MEC, como a criação do Programa Nacional de Educação Pré-Escolar, lançado em 1981, caracterizado por: compromissos oficial e formal com a educação da criança de quatro a seis anos; estabelecimento de metas de atendimento; alocação de recursos financeiros no orçamento do Ministério; e proposição da elaboração de programas municipais e estaduais de educação pré-escolar (DIDONET, 1992, p.22). O MEC concebeu a educação pré-escolar integrada ao sistema de ensino, conforme destaque: "a educação pré-escolar é agora considerada como a primeira fase da educação, pois estabelece a base de todo processo educativo" (BRASIL, 1981, p. 5), e justifica a importância dos primeiros anos de vida para o desenvolvimento da pessoa e necessidade de paliar as condições socioeconômicas precárias da maioria da população do país. Contudo, o programa propunha a expansão da educação pré-escolar tendo como base a continuação da improvisação dos espaços, a não profissionalização daqueles que trabalhavam junto às crianças, denominados "monitores", além da participação voluntária da comunidade e do baixo investimento público, mas com um tratamento explícito mais político, pois definiu a educação enquanto componente da política social, capaz de reduzir as desigualdades sociais e construir uma sociedade mais justa, o que já significava um grande avanço (DIDONET, 1992).

As ações dos movimentos sociais em prol de uma nova Constituição, dentre eles o Movimento Criança Pró-Constituinte e o Movimento de Mulheres/Feminista, contribuíram para o reconhecimento do direito à educação da criança pequena, de 0 a 6 anos, complementar à família, até o ponto de ser promulgada na Constituição de 1988. Aqui se reconhece a criança como sujeito social de direitos e a Educação Infantil como "extensão do direito universal à

\footnotetext{
${ }^{29}$ O Movimento de Luta por Creches, assim como os demais movimentos populares urbanos, foi gerado a partir de mudanças estruturais e conjunturais, com a incorporação da mão de obra feminina das diferentes classes sociais no mercado de trabalho, possibilitando às mulheres uma tomada de consciência e fornecendo às mesmas condições objetivas de organização e luta por seus direitos.
} 
educação para as crianças de 0 a 6 anos e um direito de homens e mulheres trabalhadores a terem seus filhos pequenos cuidados e educados em creches e pré-escolas" (ROSEMBERG, 2003, p.183). A sanção da Carta Magna da República Federativa do Brasil representou um grande passo na consolidação social e política da educação pública como resultado do restabelecimento do poder democrático. Ao ser promulgado, em 5 de outubro de 1988, esse documento ficou conhecido como "Constituição cidadã", por ser considerada a mais completa de todas as constituições em termos de princípios, direitos sociais e garantias fundamentais como em regulamentos de critérios de organização do Estado, dos poderes financeiros e da ordem social. A preocupação pelos direitos do cidadão consagrada nessa Constituição transcendeu o âmbito dos adultos, pois as crianças, pela primeira vez, foram concebidas como cidadãos. A lei respaldou, portanto, o dever da família, da sociedade e do poder público com a proteção e a educação das crianças de 0 a 6 anos de idade, atribuindo ao Estado o dever universal de provedor.

Art. 205. A educação, direito de todos e dever do Estado e da família, será
promovida e incentivada com a colaboração da sociedade, visando ao pleno
desenvolvimento da pessoa, seu preparo para o exercício da cidadania e sua
qualificação para o trabalho.
Art. 208 - O dever do Estado com a educação será efetivado mediante a garantia de
(...)
IV - atendimento em creche e pré-escola às crianças de zero a seis anos de idade.

No que tange à organização do Estado, a Constituição de 1988 promulga que a EI é responsabilidade prioritária do município em colaboração com as outras esferas de governo, defendendo a gestão educativa democrática acorde com os valores do Estado federativo:

Art. 206. O ensino será ministrado com base nos seguintes princípios:

I - igualdade de condições para o acesso e permanência na escola;

II - liberdade de aprender, ensinar, pesquisar e divulgar o pensamento, a arte e o saber;

III - pluralismo de idéias e de concepções pedagógicas, e coexistência de instituições públicas e privadas de ensino;

IV - gratuidade do ensino público em estabelecimentos oficiais;

V - valorização dos profissionais do ensino, garantido, na forma da lei, planos de carreira para o magistério público, com piso salarial profissional e ingresso exclusivamente por concurso público de provas e títulos, assegurado regime jurídico único para todas as instituições mantidas pela União;

VI - gestão democrática do ensino público, na forma da lei;

VII - garantia de padrão de qualidade.

Art. 211. A União, os Estados, o Distrito Federal e os Municípios organizarão em regime de colaboração seus sistemas de ensino. $\S 1^{\circ}$ A União organizará e financiará o sistema federal de ensino e o dos 
Territórios, e prestará assistência técnica e financeira aos Estados, ao Distrito Federal e aos Municípios para o desenvolvimento de seus sistemas de ensino e o atendimento prioritário à obrigatória. $\S 2^{\circ}$ Os Municípios atuarão prioritariamente no ensino fundamental e préescolar.

Art. 212. A União aplicará, anualmente, nunca menos de dezoito, e os Estados, o Distrito Federal e os Municípios vinte e cinco por cento, no mínimo, da receita resultante de impostos, compreendida a proveniente de transferências, na manutenção e desenvolvimento do ensino.

Para dar maior precisão legislativa aos temas de infância, provisão, atenção e proteção, em 1990 foi promulgado o Estatuto da Criança e do Adolescente - ECA. Criado para substituir o Código de Menores de 1979, o ECA apresentou mudanças no tratamento da infância. Importante é ressaltar os artigos referentes à Educação Infantil:

\footnotetext{
Art. 53 - A criança e o adolescente têm direito à educação, visando ao pleno desenvolvimento de sua pessoa, preparo para o exercício da cidadania e qualificação para o trabalho, assegurando-se-lhes:

I - igualdade de condições para o acesso e permanência na escola;

$\mathrm{V}$ - acesso à escola pública e gratuita próxima de sua residência.

Art. 54 - É dever do Estado assegurar à criança e ao adolescente:

IV - atendimento em creche e pré-escola às crianças de 0 a 6 anos de idade.
}

Toda esta referência legal sustenta o renovado caráter da Educação Infantil que transitou nessa época, desde a visão de assistência/caridade para a população pobre até um direito para todas as crianças. Com novos ares de abertura democrática, a equipe que assumiu a Coordenação de Educação Infantil (COEDI) do MEC elaborou uma nova política para a área da EI que se afastou do modelo não formal com baixo investimento público, assumindo metas de expansão com critérios de qualidade e propondo a indissociabilidade entre cuidado e educação. Rosemberg (2003a, p. 35) destaca que “observa-se, nesse período, a hegemonia de uma concepção de EI que não diferencia creches de pré-escolas pelo padrão de qualidade, pela formação dos educadores e pela responsabilidade administrativa". As iniciativas buscaram operacionalizar as conquistas da Constituição Federal no Plano Decenal de Educação para Todos (1993), em que foram contempladas duas diretrizes que traduzem esse compromisso: a) a equivalência de creches e pré-escolas, ambas tendo por função educar e cuidar de crianças pequenas como expressão do direito à educação; e b) a formação equivalente para o profissional de creche e pré-escola, em nível secundário e superior. Da mesma maneira, as políticas públicas estaduais e municipais implementadas beneficiaram-se dos questionamentos provenientes de enfoques teóricos de diversas áreas do saber e de processos mais democráticos desencadeados no período. 
A nova Política Nacional de Educação Infantil (BRASIL, 1994) fundamenta-se nos princípios constitucionais e reitera que a Educação Infantil deve ser oferecida em complementação à ação da família, cumprindo duas funções indissociáveis: cuidar e educar. Para tanto, deve

(...) proporcionar condições adequadas de desenvolvimento físico, emocional, cognitivo e social da criança e promover a ampliação de suas experiências e conhecimentos, estimulando seu interesse pelo processo de transformação da natureza e pela convivência em sociedade (BRASIL, 1994, p. 15).

Para o atendimento de tais diretrizes, o documento enumera ações a serem efetivadas numa perspectiva de parceria entre os diferentes atores envolvidos na Educação Infantil. Entre tais ações, prevê a Gestão Democrática fundamentada no “incentivo à elaboração, implementação e avaliação de propostas pedagógicas, especialmente àquelas que visem à promoção da função educativa da creche" (BRASIL, 1994, p. 24), ações essas acompanhadas e avaliadas pelo Ministério da Educação. Embora esse novo "status" outorgado à EI tenha ganhado centralidade no âmbito social, não esteve fora de problemáticas, principalmente pelo verdadeiro significado que trouxe esta educação de infância para a organização do poder público descentralizado do país, que exigiu a definição de normas de gestão nas distintas esferas de governo para atender aos princípios de direito, participação e gestão nacional e local.

Dos referentes oficiais, é possível resgatar as atribuições da União - como poder do Estado - e dos Municípios - como poder local - no que se refere à gestão dos centros de atendimento como ponto crucial para a democratização da educação. Em ambos, adverte-se a importância da organização autônoma do município como principal responsável da implementação e da administração da Educação Infantil, assim como do regime de colaboração a ser mantido com a União, cuja função é preponderantemente propositiva.

Vários documentos nos anos próximos, elaborados pelo MEC, através da Coordenação de Educação Infantil - COEDI, com a participação de pesquisadores da área, demonstraram que a Educação Infantil estava efetivamente na pauta de discussão do MEC. Esses documentos foram produzidos no sentido de proporcionar referenciais para pautar as ações no âmbito da EI brasileira, assim como marcar um precedente em prol da política de Educação Infantil. Em 1993, foi publicado "Política de Educação Infantil - Proposta"; em 1994, "Educação infantil no Brasil: situação atual" e "Por uma política de formação do profissional de Educação Infantil"; em 1995, foi apresentado o documento "Critérios de atendimento de uma creche que respeita os direitos fundamentais da criança”, de autoria de Fúlvia Rosemberg 
e Maria Malta Campos, pesquisadoras da FCC, encomendado pela COEDI-MEC e, em 1996, o documento "Propostas pedagógicas e currículo em Educação Infantil: um diagnóstico e a construção de uma metodologia de análise".

Porém, parecendo demarcar uma "interrupção" nos ares democráticos iniciados com a promulgação da Constituição Federal, inicia-se outro período nas políticas voltadas para a Educação Infantil no Brasil, com novas transformações na concepção hegemônica de Estado e das políticas sociais.

\subsubsection{A Reforma do Estado e a LDB (1994-2001)}

Embora a Constituição de 1988 tenha sido aprovada num contexto social e político que tendia à democratização e aos movimentos cidadãos pelo respeito de direitos, os impactos da globalização e das políticas neoliberais preconizadas por agências internacionais instalaram um conjunto de transformações ao longo daquela época que alteraram a concepção hegemônica do Estado brasileiro e das políticas sociais. Referindo-se a tal conjuntura, Campos (2002, p.28) afirma "que quando as políticas econômicas de ajuste - com suas consequências, como a contenção do crescimento econômico e dos gastos sociais - foram implantadas no país, o momento pós-constituinte acaba sendo o momento dos retrocessos nas áreas sociais e não o momento de realização do que a Constituição consagrava como avanços em termos de definições legais". Segundo a autora, os novos contornos adquiridos pela Educação Infantil na Constituição foram interrompidos pelo governo de Fernando Henrique Cardoso, que assumiu a Presidência da República em 1994 e incorporou, no plano das políticas econômicas, as orientações do FMI, e, no plano das políticas educacionais, as orientações do BM.

Em seu primeiro mandato, Fernando Henrique Cardoso criou o Ministério da Administração e Reforma do Estado - MARE, para promover e coordenar a Reforma do Aparelho do Estado Brasileiro, que serviu como instrumento de orientação legal e de divulgação da reestruturação pela qual o Estado Brasileiro iria passar nos anos seguintes. Essa reforma teve como principais diretrizes o ajuste fiscal, a redução do papel do Estado, a racionalização dos recursos, a profissionalização do serviço público e a focalização das políticas sociais. O documento do MARE, segundo a análise de Correa (2011), tenta estabelecer uma diferença entre as propostas do governo FHC e o neoliberalismo, contudo, partem da mesma avaliação de que existe uma crise do Estado que é uma crise fiscal, que sua 
solução exige uma redução do tamanho desse mesmo Estado, suas desregulamentação e privatização. Similar ao acontecido em outros países de América do Sul, a reforma adota critérios do mercado no campo educacional, alinhando as políticas educacionais às políticas de desenvolvimento econômico (ROSEMBERG, 2003b). Na área da EI, há uma retomada dos programas não formais de baixo custo e da prioridade de investimentos públicos no ensino fundamental destinado às crianças pobres. O Banco Mundial estende sua influência à Educação Infantil brasileira, na década de 1990, recuperando propostas equivalentes às da UNESCO e da UNICEF, efetuadas no país nos anos 1970. Sobre as orientações do BM, Rosemberg (2003b, p.190) assinala que "redundam, na maioria das vezes, em atendimento incompleto e de baixa qualidade, provocando novos processos de exclusão, pois se destinam particularmente aos segmentos populacionais mais pobres". Nesse contexto, foi aprovada a Lei de Diretrizes e Bases da Educação Nacional (LDB) - Lei 9394/96, que, ao mesmo tempo em que garante algumas conquistas da $\mathrm{CF}$, posiciona-se de maneira vaga quanto a outras em torno da Educação Infantil, especialmente no que diz respeito ao financiamento e à garantia de qualidade.

Assim, conforme a LDB, existe o reconhecimento do caráter educativo das creches tentando romper com a herança assistencialista. Há, também, uma definição de propostas pedagógicas para as crianças pequenas, as quais possam garantir a aprendizagem e o desenvolvimento infantil respeitando as particularidades dessa faixa etária.

Art. 29 - A educação infantil, primeira etapa da educação básica, tem como finalidade o desenvolvimento integral da criança até seis anos de idade, em seus aspectos físico, psicológico, intelectual e social, complementando a ação da família e da comunidade.

Art. 30 - A educação infantil será oferecida em:

I - creches, ou entidades equivalentes, para crianças de até três anos de idade;

II - pré-escolas, para as crianças de quatro a seis anos de idade.

Ademais, a LDB garante uma educação pública gerida com a participação da comunidade dentro e fora da escola, e assegura autonomia pedagógica, administrativa e financeira, sustentada sempre em princípios de igualdade, integração e qualidade educacional. Segundo o discurso da lei, a nova identidade institucional atribui que a instituição seja um espaço de educação de qualidade, permitindo vivências e experiências educativas, comprometida com os direitos fundamentais da criança e garantindo a promoção da cidadania. 
VIII - gestão democrática do ensino público, na forma desta Lei e da legislação dos sistemas de ensino.

Art. 14 - Os sistemas de ensino definirão as normas da gestão democrática do ensino público na educação básica, de acordo com as suas peculiaridades e conforme os seguintes princípios:

I - participação dos profissionais da educação na elaboração do projeto pedagógico da escola.

II - participação das comunidades escolar e local em conselhos escolares ou equivalentes.

Art. 15 - Os sistemas de ensino assegurarão às unidades escolares públicas de educação básica que os integram progressivos graus de autonomia pedagógica e administrativa e de gestão financeira, observadas as normas gerais do direito financeiro.

Não obstante, a efetivação e a sistematização da Educação Infantil como primeira etapa da Educação Básica registraram distâncias entre os marcos legislativos e sua aplicabilidade, o que intensificou tensões e dissensos entre a organização do Estado Federativo brasileiro e sua Educação Infantil, importantes de se descrever:

\section{a) Organização e estrutura da Educação Infantil}

Em relação à organização e à administração da oferta, o artigo 19 da LDB estabelece o amplo espectro em que podem ser classificados os diferentes tipos de instituições: i) Públicas: aquelas criadas, mantidas e administradas pelo poder público (federal, estadual e municipal); e ii) Particulares: aquelas financiadas e administradas por pessoas físicas e/ou jurídicas particulares. Neste grupo, a Lei estabelece que as instituições particulares também possam se catalogar em (art. 20):

-Particulares stricto sensu: Financiadas e administradas apenas com financiamento privado, incluindo o pagamento das famílias.

-Comunitárias: Criadas por grupos de pessoas naturais ou jurídicas, inclusive cooperativas que tenham financiamento de representantes da comunidade. Além, estas entidades podem receber financiamento público assim como com empresas privadas sem fins lucrativos.

-Confessionais: Fundadas por uma ou mais pessoas naturais ou jurídicas que professam uma orientação religiosa ou ideologia específica. Mesmo que o tipo anterior, estas instituições podem receber outros financiamentos de origem pública ou privada.

-Filantrópicas: Criadas com o objetivo de atender a um público específico pertencente a comunidades pobres ou necessitadas sem fins lucrativos. Também podem receber financiamento público ou privado.

Cabe destacar que grande parte das instituições que partilham as fontes de financiamento entre o público e o privado igualmente têm incidência no âmbito da educação pública. O poder público, ao não conseguir dar conta da demanda, estabeleceu acordos ou 
"convênios" com instituições, nomeando-as "conveniadas" desde que atendam determinadas condições, como: provar que o destino dos fundos não é lucrativo; aplicar seus excedentes financeiros em educação e transferir o patrimônio a outro estabelecimento comunitário, filantrópico, confessional ou ao poder público, no caso de terminar suas atividades. Do mesmo modo, esses convênios são integrados às estatísticas e às exigências municipais, como à implementação das políticas, ocupando um lugar legítimo no sistema público.

A determinação de incorporar a Educação Infantil como primeira etapa da Educação Básica reconheceu as creches como centros de atendimento para crianças de 0 a 3 anos 11 meses, e as pré-escolas para aquelas na faixa etária de 4 a 6 anos. A LDB determinou que todas as ações de atendimento das instituições, coordenação de políticas e responsabilidade governamental sejam atribuições do Ministério de Educação e das Secretarias Estaduais e Municipais de Educação, o que implicou uma "passagem" das instituições que até esse momento dependiam da área assistencial, para a educacional com o objetivo de melhorar as condições de atendimento e integrar o entendimento do direito da criança e a gestão democrática sob uma mesma direção.

Porém, esse processo gerou controvérsias entre as áreas educacionais e de assistência social pela gestão e pelo financiamento das instituições de Educação Infantil. Aconteceu que, em geral, segundo o exposto por Rosemberg (2007), essa "passagem" foi marcada pela convivência, muitas vezes ambígua, de dois sistemas: o das instituições, que sempre pertenceram às redes municipais de educação (EMEIs) e o sistema das instituições que "migraram" da área assistencial para entrar nos sistemas de educação (CEIs) ${ }^{30}$. Faria (2005) afirma que a grande novidade e o forte desafio que a LDB apresenta é essa união, na primeira etapa da educação básica, das crianças de 0-3 anos com as de 4-6 anos, de modo que creches e pré-escolas deixassem de estar restritas aos programas governamentais de assistência às crianças pobres. A autora destaca o significado dessa união, afirmando que se tratam de "duas redes diferentes, duas carreiras diferentes, dois diplomas diferentes, duas secretarias diferentes, junção também dos direitos de usuários distintos: os adultos trabalhadores (mulheres e homens, rurais e urbanos) e as crianças de 0 a 6 anos" (FARIA, 2005, p.1025). Contudo, as tensões e as discussões surgiram não só desde a novidade da coexistência entre o assistencial e o educativo - que legitima sem dúvida, a proposta do equilíbrio entre cuidar e educar - mas também porque precisamente essa dimensão colocou em evidência a fragmentação e a debilidade das estratégias de gestão de alguns municípios. Os debates em

\footnotetext{
${ }^{30}$ EMEI: Escola Municipal de Educação Infantil

CEI: Centro de Educação Infantil
} 
torno destas questões se tornaram muito mais complexos do que era esperado e se converteram em foco de pesquisas acadêmicas: enquanto a pré-escola se caracterizava por ter um cunho mais escolarizante a creche parecia que também devia assumir esse caráter, embora envolva também outros cuidados que requerem integração de diferentes órgãos públicos e fontes de financiamento.

Em um prazo de 10 anos, o objetivo de integração institucional, em muitos casos, contrastou com o objetivo diferenciado que levaram historicamente as instituições a serem integradas, estas que possuíam diferentes propostas e distintos modos de trabalho. Embora tenha sido sustentada pela busca global de qualidade da educação pública como direito universal, pesquisadores como Campos afirmam que, até 2002, em alguns casos, o processo de integração levado pelos municípios deveu ser acompanhado de recursos financeiros adequados, mas foi decorrente de um processo demorado, custoso e estratificado, embora hoje seja possível afirmar que o processo de integração das creches é um processo consolidado em todo o país.

\section{b) Financiamento}

Coerente com o sistema federativo brasileiro, o financiamento educacional é dividido entre as esferas federal, estadual e municipal, compondo um fundo fiscal de acordo com percentuais estabelecidos. Segundo Correa $(2011$, p.21) as reformas promovidas pelo governo de Fernando Henrique Cardoso tiveram como resultado principal o fortalecimento das relações público-privado e do estabelecimento do "público não estatal", diminuindo-se, assim, a ação do Estado na oferta direta de serviços e bens sociais, tais como educação e saúde. As mudanças no padrão de gestão do Estado a respeito dessas reformas e suas características neoliberais incidiram nas políticas de financiamento da educação pública e, direta ou indiretamente, sobre a oferta de EI nesse período. A autora exemplifica essa situação com a aprovação do FUNDEF $^{31}$ em 1996 e com a entrada em vigor para todo o país em 1998. Com a priorização econômica do ensino fundamental segundo as indicações do BM, no FUNDEF somente o ensino fundamental foi eleito como destinatário das verbas públicas, descolocando assim as definições governamentais para manter o foco financeiro no acesso à Educação Infantil pública das crianças pobres (CAMPOS, 2002), evidenciando com políticas neoliberais

\footnotetext{
${ }^{31}$ Foi instituído pela Emenda Constitucional n. ${ }^{\circ}$ 14, de setembro de 1996, e regulamentado pela Lei n. ${ }^{\circ} 9.424$, de 24 de dezembro do mesmo ano, e pelo Decreto ${ }^{\circ} 2.264$, de junho de 1997. Foi implantado, nacionalmente, em $1^{\circ}$ de janeiro de 1998, quando passou a vigorar a nova sistemática de redistribuição dos recursos destinados ao Ensino Fundamental. Vigorou de 1997 a 2006 e foi substituído pelo Fundo de Manutenção e Desenvolvimento da Educação Básica e de Valorização dos Profissionais da Educação (Fundeb).
} 
já chamadas de "minimalistas" a relação com a educação das crianças de 0 a 6 anos, que muitas vezes não tiveram sequer a criança como alvo, nem se pronunciaram a respeito da primeira etapa da educação básica” (FARIA, 2005, p. 1029).

Desde o ponto de vista da gestão administrativa e da oferta, a ausência da EI no FUNDEF teve importante repercussão sobre as matrículas nesse nível, o que ficou demonstrado pelo estudo de Arelaro (1999), que registra que houve, na maioria dos municípios, queda ou estagnação na oferta dessa etapa educacional. Dessa maneira, a determinação do município como principal administrador dos recursos sofreu mais de uma controvérsia: se por um lado, permitiu a conexão direta desse nível com a realidade local, "paradoxalmente o situou no elo mais fraco da corrente federativa" (GOMEZ, 2004, p.105), especificamente na ênfase da consecução de objetivos nacionais e medidas de financiamento por parte da gestão municipal, a que, paulatinamente, constatou grandes diferenças em nível nacional. Como evidência, a comissão da UNESCO/OCDE apresentou um panorama da Educação Infantil brasileira que avaliou as mudanças legais introduzidas na década de 1990 de maneira bastante positiva, porém constatou a permanência de entraves sérios em relação à ação municipal. Por sua vez, o Relatório de Avaliação da Política de Educação Infantil no Brasil (2009), patrocinado pelo Ministério de Educação, registrou índices insuficientes relacionados à ampliação de vagas nas instituições, à distribuição de recursos e à efetivação da gestão democrática no período de 1998 a 2003, variáveis que afetam de maneira negativa os objetivos do país e ameaçam a efetividade da Política Nacional.

Outra medida financeira de impacto, segundo Correa (2011, p.22), que trouxe consequências negativas para toda a educação, mas, de modo acentuado, para a Educação Infantil, foi a aprovação da Lei de Responsabilidade Fiscal (LRF - Lei complementar ${ }^{\circ}{ }^{101}$, de 05 de maio de 2000), que

(...) entre outras alterações na gestão financeira dos poderes públicos municipais,
estaduais e federais, estabeleceu, em seu Art. 19 , que "a despesa total com pessoal,
em cada período de apuração e em cada ente da Federação, não poderá exceder os
percentuais da receita corrente líquida" (BRASIL, 2000). No caso dos municípios e
estados, esse percentual foi definido em $60 \%$. Essa "proibição legal" de
comprometer suas despesas com contratação de pessoal acima do percentual
estabelecido produziu um incremento da busca por "alternativas", por parte dos
municípios, que não implicassem gastos com folha de pagamento e, globalmente,
fossem mais baratas aos cofres públicos.

Dessa maneira, pode se confirmar que tanto o FUNDEF como a LFR foram normativas que, na prática, favoreceram a "privatização" do atendimento. O reforço e a legitimação das instituições conveniadas com financiamento misto, assim como a 
"sobrecarga" de alguns municípios em torno da administração da EI, pôs em dúvida a Gestão Democrática e o Regime de Colaboração constatados na CF/88 entre as distintas esferas de governo, e deixou em evidência as limitações nas políticas que parecia visar à descentralização financeira, mas com controle centralizado.

\section{c) Referencial Curricular}

Em 1998, o MEC, por iniciativa da SEF/DPE/COEDI, publicou o documento Subsídios para o Credenciamento e o Funcionamento das Instituicões de Educação Infantil. Essa publicação, organizada por conselheiros representantes dos Conselhos de Educação de todos os estados e do Distrito Federal, com a participação de representantes da União Nacional dos Conselhos Municipais de Educação de membros convidados da Câmara de Educação Básica do Conselho Nacional de Educação, de consultores e especialistas, sob a coordenação de dirigentes do MEC, contribuiu significativamente para a formulação de diretrizes e normas para a Educação Infantil no Brasil.

Em 1998, foi publicado o "Referencial Nacional Curricular para a Educação Infantil" (RCNEI), com orientações pedagógicas para a construção do projeto curricular das instituições infantis, apontando as metas de qualidade de desenvolvimento integral e o respeito aos direitos das crianças como cidadãos expressados na Constituição e na LDB. Nesse sentido, o documento destaca os princípios para um processo ensino-aprendizagem em que as crianças possam se desenvolver, construir conhecimentos e paralelamente se tornar autônomas, constituindo, assim, uma proposta curricular oficial para creches e pré-escolas, destinada a apresentar orientações nacionais para o trabalho pedagógico com crianças. Correa, citando a Barreto (2011) afirma que embora sem caráter obrigatório, o Referencial "foi amplamente divulgado em todo o território nacional, sendo distribuído a todos os professores de Educação Infantil do país e, como meio de forçar sua adoção, o governo estabeleceu que a liberação de recursos para formação de professores dessa etapa educacional só ocorreria onde o RCNEI estivesse sendo adotado como currículo oficial" (Correia, 2011, p.22)

Ao ano seguinte, são aprovadas as "Diretrizes Curriculares Nacionais para a Educação Infantil” (BRASIL, 1999), estas sim, com caráter mandatório. Como referência legal, esse documento foi reconhecido como uma completa iniciativa da Política Nacional de Educação Infantil do país, constituindo-se no dispositivo para organizar os sistemas de ensino, as propostas e as avaliações pedagógicas, assim como orientar a construção de ambientes significativos e a formação de eficientes equipes de trabalho. 
As DCNEIs consideram que a função sociopolítica e pedagógica das unidades de Educação Infantil inclui (Resolução CNE/CEB no 05/09 artigos $7^{\circ}$ ):

a. Oferecer condições e recursos para que as crianças usufruam seus direitos civis, humanos e sociais.

b. Assumir a responsabilidade de compartilhar e complementar a educação e cuidado das crianças com as famílias.

c. Possibilitar tanto a convivência entre crianças e entre adultos e crianças quanto à ampliação de saberes e conhecimentos de diferentes naturezas.

d. Promover a igualdade de oportunidades educacionais entre as crianças de diferentes classes sociais no que se refere ao acesso a bens culturais e às possibilidades de vivência da infância;

e. Construir novas formas de sociabilidade e de subjetividade comprometidas com a ludicidade, a democracia, a sustentabilidade do planeta e com o rompimento de relações de dominação etária, socioeconômica, étnico racial, de gênero, regional, linguística e religiosa.

Todavia, nos primeiros anos, as Diretrizes tiveram pouco impacto nas creches e préescolas do Brasil, sendo, na maioria dos casos, totalmente desconhecidas. Porém, atualmente, são amplamente usadas na organização pedagógica das instituições.

Aliás, finalizando o mandato de Fernando Henrique Cardoso, em 2001 foi criado o Plano Nacional de Educação (PNE), com formato decenal, que:

(...) é um instrumento da política educacional que estabelece diretrizes, objetivos e metas para todos os níveis e modalidades de ensino, para a formação e valorização do magistério e para o financiamento e a gestão da educação, num período de dez anos. Sua finalidade é orientar as ações do poder público nas três esferas da administração: União, estados e municípios, o que o torna uma peça-chave no direcionamento da política educacional do país. Os principais objetivos do PNE é a elevação do nível de escolaridade da população, a melhoria da qualidade do ensino em todos os níveis, a redução das desigualdades sociais e regionais e a democratização da gestão do ensino público, obedecendo aos princípios da participação dos profissionais da educação na elaboração da proposta pedagógica da instituição e a participação da comunidade interna e externa em conselhos escolares (...) (MENESES, 2012, p.46)

No que tange a Educação Infantil, o Plano Nacional de Educação (2001-2011) reafirma a inclusão desse nível à Educação Básica, em sintonia com a LDB, atendendo a um processo de "alta qualidade" centrado na ampliação de vagas, garantia de acesso e permanência da criança na instituição pública e na qualificação de professores.

Foram estabelecidas dez metas para o prazo de dez anos:

- Ampliar a oferta da E.I para 30\% das crianças de 0 a 3 aos em creches até 2006.

- Ampliar a oferta de E.I para $60 \%$ das crianças de 4 a 6 anos nas pré-escolas até 2006.

- $\quad$ Ampliar a E.I para 50\% das crianças nas creches de 0 a 3 anos até 2011.

- Ampliar a E.I para 80\% das crianças de 4 a 6 anos nas pré-escolas e para 100\% das crianças de 6 anos até 2011. 
- Elaborar padrões mínimos de infraestrutura para todas as creches e préescolas até 2006.

- Garantir que até 2006 os professores de EB tenham formação mínima de nível médio.

- Garantir que até 2011 os professores de EB tenham formação nível superior.

- Implantar um sistema de supervisão da Educação Infantil em todos os municípios até 2004.

- Garantir alimentação para todas as crianças matriculadas em instituições de Educação Infantil.

- Implantar gradualmente período integral para a Educação Infantil (não foi fixado um prazo).

Advoga-se também pela execução da formação de Conselhos Escolares com participação de profissionais da educação e das comunidades na construção de projetos escolares; e a descentralização do financiamento, da administração da educação e do controle dos recursos financeiros (BRASIL, 2001).

O PNE consolida a importância da ação municipal em torno da expansão de cobertura. Porém, Correa (2011) destaca que tanto o PNE quanto as regulamentações legais e políticas públicas desse período - FUNDEF, LRF, Referencial Curricular- não estiveram voltadas às demandas específicas do nível nem da realidade local. Na verdade, como normativas nacionais se centraram no intuito de ampliação de vagas em EI, paradoxalmente a partir da limitação do poder financeiro da União nessa tarefa, deixando maioritariamente responsável dos "resultados" à administração municipal. A ambiguidade aqui registrada se evidencia em estudos - entre eles o de Pinto (2007) - que vaticinaram que, desde a sua aprovação, as metas do FUNDEF e do PNE eram muito pouco prováveis de alcançar, nos anos subsequentes, e, ainda, revelariam mais tensões sobre o funcionamento e a concepção da EI no Brasil. Para confirmar essas afirmações, explorar-se-á o seguinte período histórico.

\subsubsection{O governo Lula e a definição de qualidade}

Nos dois governos consecutivos de Luiz Inácio Lula da Silva (2003-2006/ 20072010), embora tenha havido continuidade em ações iniciadas no período anterior, também houve outros avanços na área da Educação Infantil.

Especial importância tem a formulação da "Política Nacional de Educação Infantil: pelo direito das crianças de zero a seis anos à Educação" (BRASIL, 2005a) e o documento "Parâmetros Nacionais de Qualidade para a Educação Infantil" (BRASIL, 2006). A primeira política salienta o perfil de qualidade da EI além do estritamente estrutural e econômico, incluindo elaboração, implementação e avaliação da proposta pedagógica a partir das DCNEIs 
de 1999. Em sintonia, o documento Parâmetros Nacionais de Qualidade para a Educação Infantil define a qualidade de educação dessa etapa, baseado nas teorias de Peter Moss e Ana Bondioli, e assinala os novos critérios que possibilitam as medidas de implementação. Explicita que "a qualidade 1) é um conceito socialmente construído, sujeito a constantes negociações; 2) depende do contexto; 3) baseia-se em direitos, necessidades, demandas, conhecimentos e possibilidades; 4) está constantemente tensionada por essas diferentes perspectivas" (BRASIL, 2006, v. 1, p.24). Distinguem-se quatro pilares sobre os quais se fundamenta a construção da qualidade: i) a concepção de criança e de Educação Infantil; ii) os debates sobre qualidade da educação em geral e o debate específico no campo da educação de infância de 0 a 6 anos; (iii) os resultados das pesquisas recentes; e (iv) a qualidade desde a perspectiva da legislação e da atuação dos órgãos oficiais do país.

É possível extrair desses dois textos oficiais a noção de qualidade de Educação Infantil como componente histórico e social decorrente dos diferentes debates gerados ao longo do tempo. A consideração do aspecto contextual e da participação de diferentes atores da comunidade na construção do conceito de qualidade sob um ambiente de respeito à diversidade cultural e étnica, assim como das realidades locais e regionais nas quais as crianças são parte, são concretizadas em um modelo que assegura a qualidade e que outorga um papel central aos governos locais, sejam estes estados, municípios ou as mesmas instituições em que o processo de determinação da qualidade em cada cenário dever ser "participativo e aberto, sendo importante em si mesmo, pois permite a reflexão e definição da própria maneira de melhorar as instituições e o trabalho educativo".

Neste sentido, definir qualidade implica:

(...) a consideração dos direitos das crianças, das mulheres e das famílias, consolidados na legislação e nos compromissos firmados pelo país no plano internacional; as diversas necessidades da criança pequena, levando-se em conta sua faixa etária, as condições de vida de sua família, as características culturais de seu meio, sua individualidade; as demandas sociais por apoio às famílias, ao trabalho e participação social da mulher e à educação infantil; os conhecimentos acumulados pela ciência nos campos da educação, da psicologia, das ciências sociais, da saúde, etc.; as possibilidades reais das instâncias responsáveis pela gestão da educação infantil e da sociedade como um todo na concretização dessas exigências (CAMPOS, 2011, p.6).

O documento "Parâmetros" elenca as competências esperadas nos sistemas federal, estadual e municipal, assim como as áreas relevantes para qualificação das instituições: i) Proposta pedagógica; ii) Gestão, iii) Professores e profissionais; iv) Interações dos docentes, administrativos e outros profissionais; v) Infraestrutura, sendo cada uma dessas áreas 
dividida em parâmetros, que no total somam dezesseis ${ }^{32}$.

Coerente com esse discurso, e segundo os estudos de Campos, Fullgraf e Wiggers (2006), os principais desafios das políticas públicas de EI na gestão do presidente Luiz Inácio Lula da Silva se centraram em financiamento, formação de professores e organização curricular. Sobre a questão do financiamento, uma medida foi a aprovação do FUNDEB (Fundo de Manutenção e Desenvolvimento da Educação Básica e de Valorização da Educação) em junho de $2007^{33}$, que corrigiu os entraves da lei de financiamento anterior (FUNDEF), e ampliou a garantia de recursos financeiros para Educação Infantil. Correa (2011) adverte que, embora deva se destacar que, no inicio, o projeto do FUNDEB não incluiu as creches em sua composição, e foi apenas como resultado de muita pressão por parte de diferentes setores da sociedade civil, com especial destaque para o Movimento Interfóruns de Educação Infantil do Brasil (MIEIB), que a situação foi revertida, o FUNDEB, uma vez incluindo as creches, trouxe relevantes contribuições para as administrações municipais na distribuição e no investimento dos recursos econômicos em "prol da aferição da qualidade do atendimento". A preocupação com o gasto empreendido por cada município com a Educação Infantil justifica-se essencialmente, pois estes passaram a dividir os seus recursos considerando o custo per capita aluno, de acordo com as matrículas anuais e a prioridade nos objetivos de integralidade e integridade da Educação Infantil desde o nascimento até os seis anos.

Para cada estado, é calculado anualmente um valor por aluno/ano, tomando como
base: os recursos provenientes da contribuição do governo estadual e dos governos
municipais daquele estado (sem os recursos de complementação da União); o
número de alunos, de acordo com o Censo Escolar mais atualizado, das redes
públicas de educação básica estaduais e municipais e das redes conveniadas de
educação infantil e educação especial; os fatores de ponderação estabelecidos para
cada uma das etapas, modalidades e tipos de estabelecimentos de ensino. (BRASIL,
2009a, p. 21-22)

A renovada importância da creche e da pré-escola fez possível a consolidação da Educação Básica como formação mínima para todo cidadão brasileiro, e sem tratamento diferenciado.

O acolhimento da reivindicação da sociedade civil no que concerne ao tratamento igual entre as etapas garantirá o significado educacional dos anos iniciais da vida com mais força de expressão perante as etapas posteriores. Isto significa dar à Educação Infantil o status de base, o que compreende que é desde o nascimento que se começa a organizar as estruturas neurológicas e psíquicas que dão sustentação a todo o percurso educacional da pessoa. (GASPAR, M. 2010)

\footnotetext{
32 Disponível em http://portal.mec.gov.br/seb/arquivos/pdf/Educinf/eduinfparqualvol2.pdf.Acesso em 23/05/2016

${ }^{33}$ Com extensão até 2020 .
} 
Porém, segundo a análise de Correa (2011), é possível extrair alguns desencontros entre a Política Nacional, os Parâmetros de Qualidade e o FUNDEB. Enquanto, nos dois primeiros documentos, manifesta-se que os custos de manutenção da Educação Infantil, especialmente na faixa entre 0 e 3 anos de idade, são superiores àqueles dos demais níveis da educação básica, assim como há diferencias entre os valores das crianças que assistem a uma instituição em período integral ou parcial, a um centro público ou conveniado, o FUNDEB e sua tendência a "não diferenciar" estabeleceu valores considerando o ensino fundamental como referência, tensão que influiu na gestão financeira das esferas municipais de governo e não minorou suficientemente a distância entre a propositura de política e sua implementação.

Com relação à formação de professores, é importante apontar que, no período anterior, pós LDB, e no governo de Fernando Henrique Cardoso, os sistemas estaduais e municipais tiveram 10 anos para formar professores, oferecendo cursos em convênios com universidades, em modalidade semipresencial ou a distância. Até 2003, 71\% dos educadores nas creches municipais contava com ensino médio exigido e $18 \%$ com formação do nível superior - sem considerar as estatísticas das instituições particulares nem conveniadas - sendo esse modelo insuficiente de formação para o magistério ${ }^{34}$. A primeira iniciativa do governo Lula, foi a criação do PROINFANTIL (Formação Inicial para Professores em Exercício na Educação Infantil), em 2005, que, de acordo ao proposto pelo MEC, era "um curso em nível médio, a distância, na modalidade Normal" destinado "aos professores da Educação Infantil em exercício nas creches e pré-escolas das redes públicas - municipais e estaduais - e da rede privada sem fins lucrativos - comunitárias, filantrópicas ou confessionais - conveniadas ou não”. Segundo informações apresentadas por Correa (2011), a expectativa do MEC era formar 23.200 professores até 2011, sem ter confirmada ainda essa quantia nos documentos oficiais.

A segunda iniciativa foi a política do Plano Nacional de Formação de Professores, instituída pelo Decreto $n^{\circ}$ 6.755, de 29 de janeiro de 2009, que advogou pela especialização do professor de Educação Infantil, em regime de colaboração entre a União, os estados, o Distrito Federal e os municípios, constituindo uma das primeiras iniciativas nacionais para incluir a formação continuada de professores nesse segmento ${ }^{35}$.

O Plano Nacional de Formação é destinado aos professores em exercício das escolas públicas estaduais e municipais sem formação adequada à LDB, oferecendo cursos superiores públicos, gratuitos e de qualidade, com a oferta cobrindo os municípios de 21 estados da Federação, por meio de 76 instituições públicas de educação

\footnotetext{
${ }^{34}$ Dados escolhidos do documento "Política de Educação Infantil no Brasil: Relatório de Avaliação" (2009)

${ }^{35}$ Documento disponível em http://portal.mec.gov.br/dmdocuments/livro.pdf. Acesso em 7/07/2016
} 
superior, das quais 48 federais e 28 estaduais, contando também com a colaboração de 14 universidades comunitárias (BRASIL, 2009, p.7).

Na primeira versão oficial do documento, é possível visualizar que o percentual de vagas disponibilizadas para formação da etapa infantil - seja primeira ou segunda licenciatura, ou curso especial, em modalidade presencial ou a distância - é proporcionalmente menor à quantidade de cursos que foram oferecidos como parte da formação dos cursos de primeiros anos de ensino fundamental. Nesse sentido, atendendo o pedido por mais cursos de formação específica no nível infantil de um número considerável de municípios, em 2010, o Ministério da Educação, em parceria com 15 universidades federais de 15 estados, ofereceu 3.210 vagas adicionais em cursos de especialização em Educação Infantil, presenciais e gratuitos. Essas vagas foram destinadas aos profissionais de escolas - professores, coordenadores, diretores de creches - e pré-escolas das redes pública e conveniadas que mantinham convênio com o poder público, e também às equipes de Educação Infantil do sistema público de ensino.

Desde a perspectiva das propostas curriculares e pedagógicas de creches e pré-escolas, no ano de 2009, o Ministério de Educação, através da Secretaria de Educação Básica, em conjunto com o Conselho Nacional de Educação, organizaram a revisão e a reformulação das Diretrizes Curriculares Nacionais para a Educação Infantil, reforçando a perspectiva de Educação Infantil como direito da criança, assim como a colaboração participativa da sociedade na tomada de decisões na construção das propostas pedagógicas. Assim, no novo documento, salientam alguns artigos

Art. $2^{\circ}$ - As Diretrizes Curriculares Nacionais para a Educação Infantil articulam-se com as Diretrizes Curriculares Nacionais da Educação Básica e reúnem princípios, fundamentos e procedimentos definidos pela Câmara de Educação Básica do Conselho Nacional de Educação, para orientar as políticas públicas na área e a elaboração, planejamento, execução e avaliação de propostas pedagógicas e curriculares.

Art. $3^{\circ}$ - O currículo da Educação Infantil é concebido como um conjunto de práticas que buscam articular as experiências e os saberes das crianças com os conhecimentos que fazem parte do patrimônio cultural, artístico, ambiental, científico e tecnológico, de modo a promover o desenvolvimento integral de crianças de 0 a 5 anos de idade.

Art. $4^{\circ}$ - As propostas pedagógicas da Educação Infantil deverão considerar que a criança, centro do planejamento curricular, é sujeito histórico e de direitos que, nas interações, relações e práticas cotidianas que vivencia, constrói sua identidade pessoal e coletiva, brinca, imagina, fantasia, deseja, aprende, observa, experimenta, narra, questiona e constrói sentidos sobre a natureza e a sociedade, produzindo cultura.

Art. $6^{\circ}$ As propostas pedagógicas de Educação Infantil devem respeitar os seguintes princípios: 
I - Éticos: da autonomia, da responsabilidade, da solidariedade e do respeito ao bem comum, ao meio ambiente e às diferentes culturas, identidades e singularidades.

II - Políticos: dos direitos de cidadania, do exercício da criticidade e do respeito à ordem democrática.

III - Estéticos: da sensibilidade, da criatividade, da ludicidade e da liberdade de expressão nas diferentes manifestações artísticas e culturais.

Art. $7^{\circ} \mathrm{Na}$ observância destas Diretrizes, a proposta pedagógica das instituições de Educação Infantil deve garantir que elas cumpram plenamente sua função sociopolítica e pedagógica:

I - Oferecendo condições e recursos para que as crianças usufruam seus direitos civis, humanos e sociais;

II - Assumindo a responsabilidade de compartilhar e complementar a educação e cuidado das crianças com as famílias;

III - possibilitando tanto a convivência entre crianças e entre adultos e crianças quanto a ampliação de saberes e conhecimentos de diferentes naturezas;

IV - Promovendo a igualdade de oportunidades educacionais entre as crianças de diferentes classes sociais no que se refere ao acesso a bens culturais e às possibilidades de vivência da infância;

V - Construindo novas formas de sociabilidade e de subjetividade comprometidas com a ludicidade, a democracia, a sustentabilidade do planeta e com o rompimento de relações de dominação etária, socioeconômica, étnico-racial, de gênero, regional, linguística e religiosa.

Destaque-se que as DCNEIs foram constituídas tal como a CF e LDB, em lei norteadora das políticas públicas de Educação Infantil de qualidade no Brasil, pois colocaram questionamentos fundamentais sobre temas de elaboração de qualquer projeto curricular nas instituições - organização do tempo e espaço, diversidade e singularidade das crianças, formação do professor, entre outros - além de relacioná-los com questões administrativas que asseguram a disponibilidade de recursos materiais e humanos para uma efetiva gestão educativa municipal.

No que diz respeito à implementação, a pesquisa intitulada Mapeamento e análise das propostas pedagógicas municipais para a Educação Infantil no Brasil (BARBOSA, 2009) levantou a situação real, da época, de grande parte dos municípios, em torno à produção de projetos curriculares próprios. A análise dos documentos de 48 municípios diferentes de quase todos os estados brasileiros - menos Roraima - evidenciou que, embora eles compreendessem que qualquer documento curricular próprio precisa estar relacionado aos marcos legais nacionais, existe dificuldade na organização de uma amostra com características semelhantes devido à ampla gama de diversidade curricular encontrada. Além da diferença de formato, terminologia, bases teóricas e científicas, muitos documentos pesquisados foram apenas a reprodução da legislação vigente, enquanto que outros incluíram a pesquisa minuciosa de documentos oficiais, como o Referencial Curricular Nacional para Educação Infantil e a Lei de Orgânica da Assistência Social. Alguns projetos foram detalhados com participação ativa das redes, mas também houve municípios que utilizaram a 
falta de infraestrutura ou recursos humanos para justificar a ausência de propostas e demandar assessoria e fiscalização externa.

Vale ressaltar também a diferença registrada entre os currículos da pré-escola e da creche. A pesquisa Educação Infantil no Brasil, Avaliação Qualitativa e Quantitativa (2012) constata negligências na programação curricular para crianças pequenas e sobre escolarização das pré-escolas, inclusive com a permanência de "turmas de alfabetização", que é um nível não reconhecido legalmente por nenhum documento oficial, mas muito comum ainda nas instituições de Educação Infantil. Com essas informações, é possível questionar as finalidades da construção curricular por parte das secretarias municipais, sustentando, com isso, os principais debates contemporâneos sobre a coerência e efetividade da ação municipal nessa área.

(...) parece então que a existência de Diretrizes Curriculares Nacionais mandatórias,
elaboradas pelo Conselho Nacional de Educação, de documentos orientadores de
âmbito nacional, divulgados pelo MEC, e demais documentos adotados por
Secretarias de Educação, por si sós, não são suficientes para fundamentar e orientar
as equipes pedagógicas e os professores em seu trabalho cotidiano com as turmas de
crianças pequenas. (FCC, 2012, p.404)

É importante salientar, ademais, que, coerente à orientação política socialista do presidente Luiz Inácio Lula da Silva, o aprimoramento de políticas sociais para o combate da pobreza dos setores mais vulneráveis da sociedade foi um eixo importante dos seus governos e significou a criação e/ou reformulação de programas sociais que repercutiram no sistema educativo, ampliando seu campo de ação e atingindo tanto as instituições de EI como as famílias com filhos na faixa etária de creche ou pré-escola. Destacam os programas complementares do segundo governo: Programa Nacional de Alimentação Escolar, com a definição de um valor per capita diferenciado para creches; Programa Dinheiro Direto na Escola, que existiu desde 1995, mas apenas em 2009 integrou a assistência financeira a instituições de EI; o programa PROINFÂNCIA (Reestruturação e Aparelhagem da Rede Escolar Pública de Educação Infantil), por meio do qual o governo federal repassou R $\$ 1,8$ bilhão entre 2007 e 2010 para a construção ou reforma de 1.022 instituições $^{36}$, e o programa de Transferência Condicional de Renda (TCR), "Bolsa Família", direcionado às famílias em situação de pobreza e de extrema pobreza em todo o país, de modo que consigam superar a situação de vulnerabilidade através da transferência mensal de uma renda auxiliar variável

\footnotetext{
${ }^{36}$ Estatísticas disponíveis em www.portal.mec.gov.br. Em 2016, não foram encontradas informações sobre se realmente se construíram e/ou reformaram as citadas instituições.
} 
conforme o número de crianças e/ou adolescentes na composição familiar, e a garantia ao acesso a serviços básicos, como educação e saúde, por exemplo ${ }^{37}$.

Seguindo o percurso histórico, foi publicado, no ano de 2009, o documento intitulado Indicadores de Qualidade na Educação Infantil, com caráter de especificação dos Parâmetros e, como proposta de qualificação da gestão baseada na autoavaliação e no desenvolvimento de capacidades internas da instituição como parte de um processo participativo e democrático.

(...) A definição dos indicadores de qualidade permitirá a criação de instrumentos para credenciamento de instituições, elaboração de diagnósticos, e mesmo a implementação propriamente dita dos parâmetros de qualidade nas instituições de Educação Infantil e nos sistemas educacionais. Os indicadores de qualidade deverão ser definidos em níveis progressivos de exigência no sentido vertical e, em âmbitos também progressivos de abrangência (local, regional, nacional), no sentido horizontal, permitindo, ainda, que cada instituição ou município incorpore indicadores de qualidade construídos pela comunidade que representam. (BRASIL, 2009, p.24)

Foi apresentado, no texto, um instrumento de autoavaliação para creches e préescolas com sete dimensões: i) Planejamento institucional; ii) Multiplicidade de experiências e linguagens; iii) Interações; iv) Promoção de saúde; v) Espaços, materiais e mobiliários; vi) Formação e condições de trabalho das professoras e demais profissionais; vii) Cooperação e troca com as famílias e participação na rede de proteção social. O sistema de avaliação interna de cada estabelecimento propõe um ciclo de melhoria que compreende quatro fases:

a) Autoavaliação: Diagnóstico em relação à qualidade da oferta além da elaboração de propostas de melhora em função de práticas que respeitem os direitos das crianças e sustentem a democratização do processo, com participação de diretores, professores e famílias. Entrega-se uma série de passos para organizar as dinâmicas junto com diretrizes sobre os materiais necessários e sugestões de repetição a cada um ou dois anos.

b) Plano de Melhoria: A partir da informação recolhida na autoavaliação, elabora-se um Plano de Melhoria que contemple seis aspectos: dimensão, indicador, problemas, ações, responsáveis e prazos.

c) Difusão de Resultados: A comunidade educativa com um formato definido.

d) Consequências dos resultados: Etapa onde são esclarecidos os resultados do processo de

\footnotetext{
${ }^{37}$ Muitos pesquisadores têm demonstrado que o Programa Bolsa Família do Brasil teve um grande impacto na redução da pobreza e da desigualdade de renda. Outros intentam explicar o impacto deste programa na educação. Segundo Glewwe e Kassouf (2010), os programas de transferência condicional de renda (TCR), como o Bolsa Família, existem para incentivar as famílias a enviarem seus filhos à escola. As TCRs têm dois objetivos: (i) redução da pobreza atual; e (ii) aumento do investimento no capital humano das crianças pobres, de modo a aumentar seu bem-estar quando se tornarem adultas. O primeiro objetivo é alcançado quando as famílias pobres recebem os pagamentos do programa. O segundo é alcançado pelo condicionamento desses pagamentos a certos comportamentos, principalmente a matrícula dos filhos nas instituições educativas.
} 
autoavaliação e melhoria para a instituição, os quais não implicam nenhum tipo de incentivo ou sanção.

O documento prioriza o trabalho de melhoria dentro das instituições, onde o município deve assumir a responsabilidade, o acompanhamento e a assistência técnica dos processos relativos às creches e às pré-escolas públicas dependentes diretas e conveniadas. Cabe também à gestão municipal realizar um processo próprio que contemple fases similares em torno à gestão das redes priorizando regiões, áreas geográficas ou localidades com maior necessidade, as quais determinem o caráter do seguimento e a fiscalização municipal.

Também em 2009 foi sancionada a Emenda Constitucional $\mathrm{n}^{\mathrm{o}} 59^{38}$, que torna obrigatória a matrícula de todas as crianças a partir dos quatro anos de idade, amplia o ensino fundamental a 9 anos e, portanto, novos desafios e entraves se apresentaram na garantia de vagas e na qualidade de oferta principalmente no que respeita à priorização de recursos da gestão municipal ${ }^{39}$. Concomitantemente, o projeto de lei que estabelece o novo Plano Nacional de Educação por mais 10 anos, encaminhado no final do governo Lula ao legislativo federal, em 20 de dezembro de 2010, para o decênio 2011-2020, especialmente para a Educação Infantil, mantém o caráter normativo e de responsabilidade primordial dos municípios, e legitima mais uma vez a opção do atendimento via convênio e a injeção de recursos econômicos como forma de intervenção da União.

Com Dilma Rousseff assumindo o governo em 2011, reafirma-se a continuidade da maioria das iniciativas do governo anterior. Aliás, observa-se a tentativa de configurar a EI promovendo a necessidade de supervisão, fiscalização e avaliação externa, implicando o envolvimento dos estados, União e do MEC, num acompanhamento efetivo do município nos processos de implementação das políticas.

Atualmente, uma das discussões mais potentes se centra na criação de uma base curricular comum nacional que detalhe os conhecimentos básicos e universais que as crianças devem aprender por direito na instituição e os alinhamentos de trabalho dentro dela. Variados têm sido os debates e divididas as opiniões; há os que estão a favor da implementação de políticas curriculares federais detalhadas, com as suficientes supervisão e avaliação externas a

\footnotetext{
38 A lei n 12.796 foi a que oficializou a mudança feita na Constituição, por meio da Emenda Constitucional n 59 em 2009, promulgada o 4 de abril de 2013. Essa lei torna obrigatório o ensino entre os 4 e os 17 anos. Além, os pais ficam responsáveis por matricular as crianças na Educação Infantil a partir dos 4 anos e por sua permanência até os 17. Já os municípios e os Estados têm até o ano de 2016 para garantir a inclusão dessas crianças na escola pública.

${ }^{39}$ Veja-se em Arelaro, L. et al. O ensino fundamental de nove anos e o direito à educação, Educação e Pesquisa, São Paulo, v.37, n.1, 220p. 35-51, jan./abr. 2011.
} 
partir de apostilas e sistemas padronizados, de modo a garantir maior equidade entre municípios, regiões e grupos étnicos-raciais, sem deixar de respeitar a diversidade local. $\mathrm{O}$ outro bloco de opinião diverge dessa visão e questiona a necessidade de unificar critérios muito detalhados em um país tão descentralizado e diverso como Brasil, o que certamente poderia ameaçar as autonomias dos seus governos municipais e instituições de educação pública, e contribuir para um retrocesso na busca da qualidade e na democratização da educação. Setores importantes e reconhecidos, como Fóruns Municipais e Estaduais de Educação Infantil e o MIEIB, União Nacional dos Dirigentes Municipais de Ensino, Anped Associação Nacional de Pós-graduação e Pesquisa em Educação, sindicatos e entidades da sociedade civil, também têm se mobilizado em favor da Educação Infantil e discutido sobre os caminhos a seguir na busca da qualidade que o Brasil requer para essa etapa educacional..

A partir do conhecimento das políticas públicas contemporâneas mais importantes do Brasil, sua historicidade e seus objetivos, verifica-se que, atualmente, existe uma clara tendência do poder público à especificação de critérios e indicadores susceptíveis de ser avaliados institucional e nacionalmente. Porém, a realidade da gestão municipal no Brasil, com toda a sua heterogeneidade, torna qualquer tentativa de avaliação nacional um exercício enormemente delicado e complexo. Do mesmo modo a generalização, inclusive de instituições do mesmo município ou estado, acompanha o risco de não ser reconhecida dentro do contexto a ser avaliado.

Em 2014, foi publicada a pesquisa Gestão da Educação Infantil nas Políticas Municipais, por Kramer, Barros e Toledo. Nela foram entrevistados profissionais atuantes nas secretarias de 24 municípios brasileiros e identificados os avanços no que se refere: a) à expansão das matrículas nas creches públicas; (b) à organização e ao funcionamento de muitas secretarias de educação que assumiram a especificidade da Educação Infantil; (c) à formação de equipes pedagógicas de acompanhamento da educação infantil. Observou-se o envolvimento das equipes que atuavam diretamente com crianças de 0 a 6 anos em projetos de formação, indicando investimento crescente na qualificação dos profissionais. Contudo, os relatos mostraram muitos desencontros relacionados às deficiências de gestão municipal e à falta de capacidades das equipes de gestores. As entrevistas possibilitaram detectar as urgências: abertura de concurso específico para professor de educação infantil; processos democráticos de nomeação de diretor, em especial nas creches; plano de cargos e salários compatível com a função docente; melhoria nas condições das instituições; formação das equipes de gestão, e pendências relacionadas à instabilidade das equipes internas por continuidades e descontinuidades das autoridades municipais, a interferência delas na 
contratação de pessoal e distribuição de cargos que repercutem na transparência do funcionamento da rede. Esse conflito inter e intragovernamental possivelmente surge devido à história política e às gestões divergentes, muitas vezes por descontinuidades e mudanças nos governos municipais que definem a articulação local com as políticas federais contemporâneas expostas ao longo desta seção. Os municípios adotaram caminhos diferentes na organização de suas redes de
Educação Infantil. Em um extremo situam-se aqueles que decidiram, há algum
tempo, investir mais em atendimento em tempo integral, inclusive oferecendo
matrículas nesse regime para as crianças na faixa etária correspondente à pré-escola.
De outro lado, os que privilegiam a oferta de vagas em pré-escolas de meio período,
minimizando as matrículas em creche. Em algumas capitais, a pesquisa constatou
um processo de municipalização de instituições antes conveniadas com a prefeitura
e/ou com o estado, enquanto que em outras existiam mecanismos de terceirização de
contratação de professores e de serviços de apoio às escolas na rede municipal.
(CAMPOS, M., 2010, p. 400)

Os resultados da pesquisa referida permitiram visualizar que ainda há uma grande distância entre o que esperam a legislação e os documentos oficiais em relação à gestão democrática, ao acesso, às condições e à formação dos profissionais. Assim, sem desvalorizar as significativas conquistas em termos de legislação e políticas públicas de caráter oficial, tanto para creche como para pré-escola, os verdadeiros avanços devem ser reconhecidos nas gestões municipais, pois também, mesmo no vazio, existem muitas redes com vontade e compromisso de gestão para construir uma educação de qualidade contextualizada e participativa. Importante menção merece a rede municipal de São Paulo, sendo a maior rede municipal de América Latina e cuja trajetória da gestão em Educação Infantil tem alcançado reconhecimento e prestígio com claro destaque nacional, inclusive nos inícios do século XX, com a criação dos Parques Infantis (PIs) ${ }^{40}$, até a atualidade, com incidência na reformulação de grande parte das legislações e normativas oficiais.

Em meio à fragilidade das condições e à precarização dos equipamentos sociais em diversos municípios, há profissionais e gestores municipais que resistem e lutam por um trabalho de qualidade entre suas instituições e dentro delas com crianças de 0 a 6 anos. Municípios pequenos, com arrecadações baixíssimas, avançam nas discussões da educação infantil de qualidade. (KRAMER et al. 2014, p.35)

\footnotetext{
${ }^{40} \mathrm{O}$ escritor brasileiro Mário de Andrade foi um dos idealizadores e o diretor do Departamento de Cultura (DC), da prefeitura de São Paulo, na gestão do prefeito Fábio Prado, quando na década de 1930. Criou, dentre tantos programas para o operariado, o Parques Infantis (PI) para seus filhos e filhas de 3 a 12 anos. Os estudos de Ana Lúcia Goulart de Faria (1995 e 1999) concluem que a concepção de criança que fundamentou o projeto dos PIs, criado para as crianças da classe operária, não as tomava como limitadas, ao contrário, concebia-as como ricas do ponto de vista da cultura, mais do que portadores de cultura, eram também capazes de criar e recriar a cultura a partir da atividade lúdica, compreendida aqui como processo de construção de conhecimentos.
} 
2.3.4 Estatísticas e conclusões preliminares

\section{Gráfico 8- Evolução da frequência de crianças em instituições de EI por faixa etária, Brasil, (\%) 1995 - 2013}

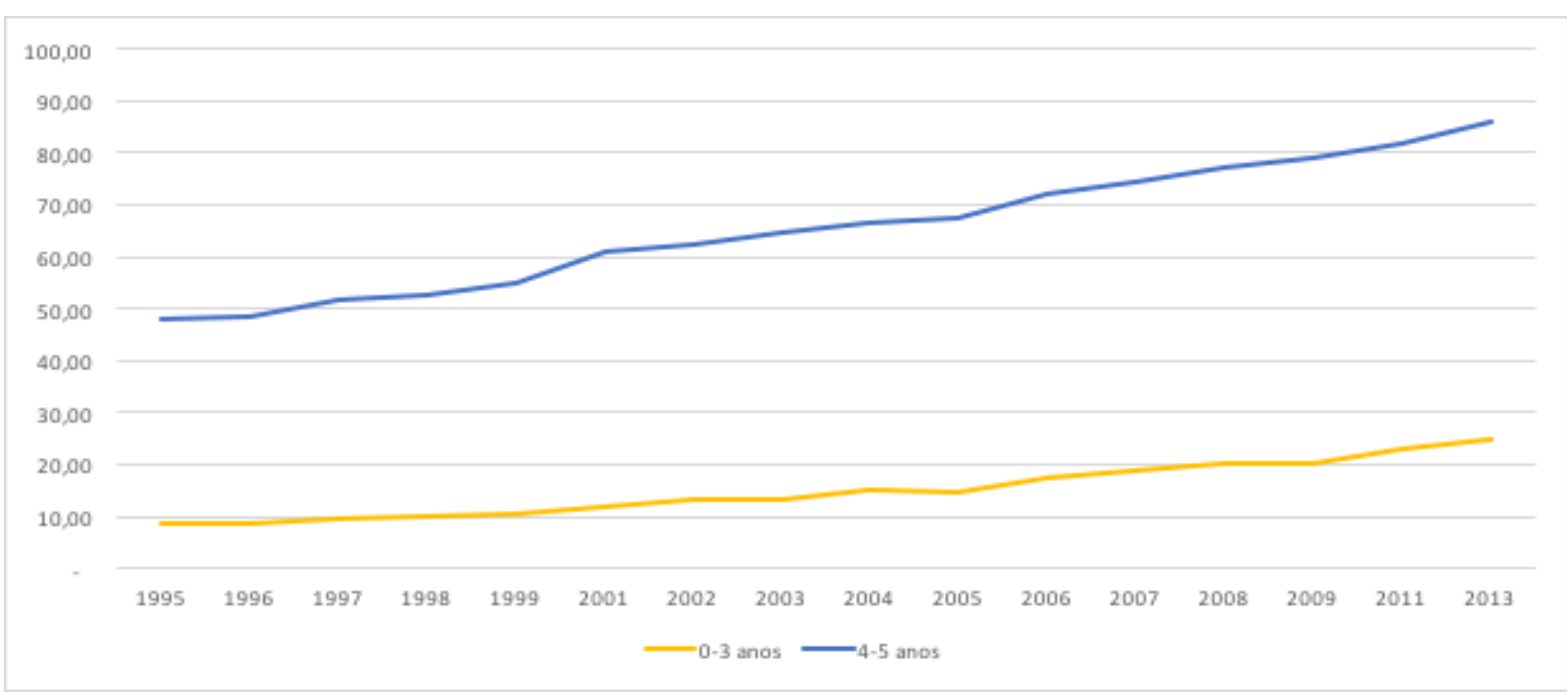

Fonte: Elaboração própria a partir dos dados do IBGE/Pnad, e do relatório Todos Pela Educação 2012. Notas: As estimativas levam em consideração a idade em anos completos em 30 de junho, ou idade escolar. Em 2004, a área rural da região Norte foi incorporada no plano amostral da Pnad. Assim, até 2003, os dados da região Norte são referentes apenas à área urbana. A partir de 2004, os valores apresentados se referem à área urbana e à área rural do Norte.

\section{Gráfico 9- Porcentagem de crianças de 0 a 3 anos que frequentam instituições de EI- Brasil - 1995-2011, por unidades da federação e regiões metropolitanas}

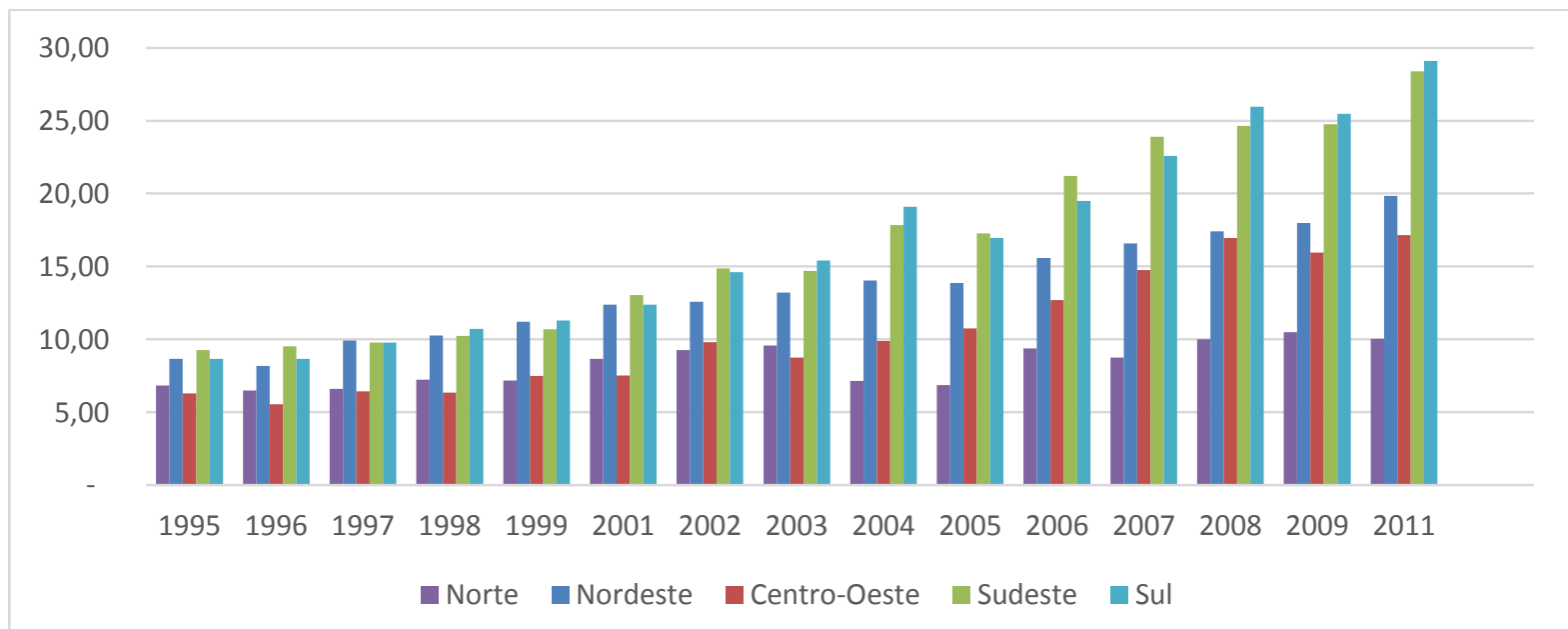

Fonte: Elaboração própria a partir dos dados do IBGE/Pnad, e do relatório Todos Pela Educação 2012. Notas: As estimativas levam em consideração a idade em anos completos em 30 de junho, ou idade escolar. Em 2004 a área rural da região Norte foi incorporada no plano amostral da Pnad. Assim, até 2003, os dados da região Norte são referentes apenas à área urbana. A partir de 2004, os valores apresentados se referem à área urbana e à área rural do Norte. 
Gráfico 10 - Porcentagem de crianças de 4 a 5 anos que frequentam instituições de EIBrasil - 1995-2011, por unidades da federação e regiões metropolitanas

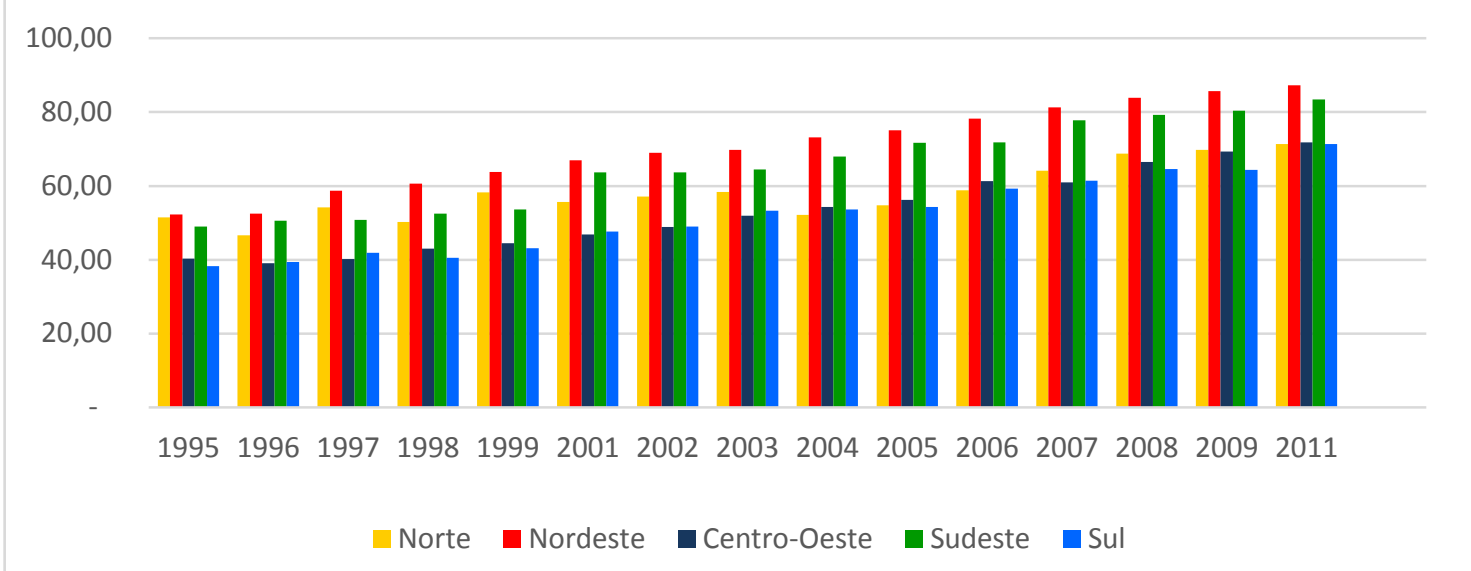

Fonte: Elaboração própria a partir dos dados do IBGE/Pnad, e do relatório Todos Pela Educação 2012. Notas: As estimativas levam em consideração a idade em anos completos em 30 de junho, ou idade escolar. Em 2004, a área rural da região Norte foi incorporada no plano amostral da Pnad. Assim, até 2003, os dados da região Norte são referentes apenas à área urbana. A partir de 2004, os valores apresentados se referem à área urbana e à área rural do Norte.

Tabela 11 - Número de matrículas por dependência administrativa da pré-escola, Brasil, anos escolhidos

\begin{tabular}{|c|c|c|c|c|}
\hline & Federal & Estadual & Municipal & Privada \\
\hline $\mathbf{1 9 9 7}$ & 2025 & 606858 & 2695893 & 987432 \\
\hline $\mathbf{1 9 9 8}$ & 1380 & 396361 & 2725755 & 987624 \\
\hline $\mathbf{1 9 9 9}$ & 1225 & 379802 & 2799420 & 1054831 \\
\hline $\mathbf{2 0 0 0}$ & 1247 & 335682 & 2995244 & 1089159 \\
\hline $\mathbf{2 0 0 1}$ & 1629 & 317861 & 3275406 & 1223907 \\
\hline $\mathbf{2 0 0 2}$ & 1751 & 302234 & 3402909 & 1270953 \\
\hline $\mathbf{2 0 0 3}$ & 1787 & 302336 & 3532969 & 1318584 \\
\hline $\mathbf{2 0 0 4}$ & 1637 & 277613 & 3792629 & 1483646 \\
\hline $\mathbf{2 0 0 5}$ & 1668 & 249001 & 4026681 & 1513320 \\
\hline $\mathbf{2 0 0 6}$ & 1538 & 225397 & 3921291 & 1439927 \\
\hline $\mathbf{2 0 0 7}$ & 1167 & 168994 & 3727934 & 1032192 \\
\hline $\mathbf{2 0 0 8}$ & 1117 & 105181 & 3743531 & 1117696 \\
\hline $\mathbf{2 0 0 9}$ & 1239 & 70152 & 3664360 & 1130517 \\
\hline $\mathbf{2 0 1 0}$ & 1189 & 63994 & 3508581 & 1118281 \\
\hline $\mathbf{2 0 1 1}$ & 1193 & 56538 & 3493307 & 1130307 \\
\hline $\mathbf{2 0 1 2}$ & 1378 & 52626 & 3527745 & 1184194 \\
\hline $\mathbf{2 0 1 3}$ & 1370 & 50111 & 3591750 & 1217250 \\
\hline
\end{tabular}

Fonte: Elaboração própria a partir dos dados do MEC/Censo Escolar Inep, anos r 
Tabela 12 - Número de matrículas por dependência administrativa das creches, Brasil, anos escolhidos

\begin{tabular}{|c|c|c|c|c|}
\hline & Federal & Estadual & Municipal & Privada \\
\hline $\mathbf{1 9 9 7}$ & 387 & 16349 & 216664 & 114612 \\
\hline $\mathbf{1 9 9 8}$ & 187 & 11585 & 246676 & 123356 \\
\hline $\mathbf{1 9 9 9}$ & 508 & 16593 & 522703 & 292174 \\
\hline $\mathbf{2 0 0 0}$ & 495 & 16373 & 565370 & 334626 \\
\hline $\mathbf{2 0 0 1}$ & 886 & 18292 & 663508 & 410661 \\
\hline $\mathbf{2 0 0 2}$ & 709 & 17955 & 698643 & 435204 \\
\hline $\mathbf{2 0 0 3}$ & 671 & 18127 & 748707 & 470053 \\
\hline $\mathbf{2 0 0 4}$ & 721 & 14993 & 828352 & 504171 \\
\hline $\mathbf{2 0 0 5}$ & 893 & 17264 & 860960 & 535226 \\
\hline $\mathbf{2 0 0 6}$ & 933 & 17582 & 898945 & 510482 \\
\hline $\mathbf{2 0 0 7}$ & 974 & 8651 & 1040670 & 529286 \\
\hline $\mathbf{2 0 0 8}$ & 1121 & 7365 & 1134944 & 608306 \\
\hline $\mathbf{2 0 0 9}$ & 1215 & 6819 & 1244731 & 643598 \\
\hline $\mathbf{2 0 1 0}$ & 1248 & 7308 & 1345180 & 710917 \\
\hline $\mathbf{2 0 1 1}$ & 1359 & 8114 & 1461034 & 828200 \\
\hline $\mathbf{2 0 1 2}$ & 1245 & 6671 & 1603749 & 936566 \\
\hline $\mathbf{2 0 1 3}$ & 1254 & 4909 & 1724714 & 999242 \\
\hline
\end{tabular}

Fonte: Elaboração própria a partir dos dados do MEC/Censo Escolar Inep, anos r

A partir do entendimento do caso brasileiro e as informações estatísticas dos três períodos descritos, é possível concluir que:

a) O Brasil vive décadas de significativas mudanças na Educação Infantil, principalmente em torno dos objetivos de expansão e de qualidade. Embora no início do primeiro período aqui exposto, o objetivo de expansão da oferta pública foi realizado sob diretrizes internacionais de combate à pobreza, com a apertura democrática da Constituição de 1988 e, em especial, com o reconhecimento das creches como direito das crianças, das famílias e dever do Estado, as transformações repercutiram na gestão educativa tanto nacional como local, com novas exigências oficiais sobre financiamento, ampliação de cobertura, formação profissional, currículo e garantia da qualidade. Esse fato é marcante enquanto à visibilidade da necessidade de garantia dos direitos educativos da infância em instituições públicas, pautadas por critérios de qualidade definidos e normatizados pelo Estado, mas administrados e implementados prioritariamente pela esfera municipal. Grande parte das pesquisas, relatórios e artigos lidos e citados no percurso da descrição do cenário brasileiro tentam mostrar os progressos e entraves da implementação no plano local em relação às orientações nacionais, confirmando que, independente das conquistas que a 
autonomia municipal trouxe para a adaptação das políticas públicas de Educação Infantil em alguns locais, ainda persistem marcadas diferenças entre gestões municipais, o que determina tensões e desencontros entre o proposto nacionalmente e sua implementação.

b) Os delineamentos efetuados na EI desde a década de 1970 podem ser percebidos nos impasses presentes na área. Numa aparente contradição, nos três períodos históricos estudados há presença ativa de grupos da sociedade civil e acadêmica, organizados e responsáveis pelo surgimento de discussões acerca do direito à EI de qualidade para todas as crianças e a produção de alguns documentos que se tornariam referências duradouras e exigências, inclusive integradas nas legislações e normativas do Estado, estando até hoje em vigência dada a sua ampla aceitação. Porém, em tempos em que a lógica de mercado tem predominado na sociedade brasileira e pautado as ações dos sucessivos governos, a legitimação e a permanência de reformas que reafirmam a redução da intervenção do Estado, a débil gestão democrática, o escasso regime de colaboração entre esferas subnacionais, a apertura neoliberal do atendimento via "convênios" justificaram a permanência e incremento de iniciativas de programas focalizados para crianças vulneráveis, o que continua colocando em xeque, até hoje, as possibilidades de efetivação dos direitos de todas crianças brasileiras.

c) O gráfico de evolução de frequência de crianças em instituições de EI revela que existiu uma expansão significativa da cobertura, obedecendo em parte ao aumento do gasto público em razão das políticas financeiras (FUNDEB principalmente) e as metas do PNE. Embora exista uma ampla diferença numérica entre os dados da creche e da pré-escola, os textos que outorgaram as informações quantitativas coincidem em que uma das razões dessa diferença indica a dificuldade de quantificar o total de matrículas nas creches, possivelmente pelo crescimento considerável do número de instituições particulares e conveniadas na época e pela crescente demanda de vagas em creches de tempo integral, que, em alguns casos, os municípios não conseguiram resolver.

d) As tabelas da evolução do número de matrículas por dependência administrativa mostram que, tanto em creche como em pré-escola, mantêm-se o mesmo padrão, ou seja, a maioria dos centros correspondem a entidades municipais, observando-se ademais uma diminuição constante ao longo do tempo de instituições federais e estaduais. No entanto, é importante destacar, a partir das estatísticas apresentadas no documento De Olho nas Metas 2012, que uma das principais estratégias dos governos 
municipais para aumentar a oferta de vagas na Educação Infantil foi a construção de novas creches e pré-escolas e a ampliação da rede por meio de aluguel de casas, prédios e imóveis sem condições adequadas para o trabalho de qualidade com as crianças e sem atender as definições legais das especificidades da Educação Infantil. Alguns municípios ainda mantêm turmas somente em escolas de ensino fundamental, enquanto outros abriram espaços exclusivos para Educação Infantil. Contudo, entre essas estratégias, a que mais chama a atenção é a oferta de tempo parcial em vez de integral, assumida pelos governos municipais como outra forma de expansão, justificando assim a variabilidade de estratégias que trouxe a tarefa de incrementar as vagas para cobrir a demanda de educação de crianças nessa faixa etária.

d) Assim, enquanto a maioria das políticas públicas mais recentes, seguindo o argumentado por Campos (2010), não estão conseguindo alterar os padrões de desigualdades sociais existentes no país, o desafio de implementação nos municípios tem exigido trabalhar pela superação das desigualdades em consonância com reformas neoliberais que respeitem a diversidade de cada contexto, tarefa enormemente complexa e até contrária, sobretudo ao considerar as pendências das normativas nacionais - principalmente no que diz respeito ao financiamento e ao acompanhamento da União às redes municipais - e a heterogeneidade de cada município que repercute nas prioridades de investimento, trazem novos riscos corrupção, uso inadequado dos recursos - e diversas interpretações sobre qualidade de Educação Infantil. Pode se dizer que políticas, programas e documentos elaborados pelo MEC por si só não mudaram a realidade, assim como não se concretizaram em ações efetivas, uma vez que foi responsabilidade prioritária dos municípios a oferta e a gestão da Educação Infantil (CAMPOS, 2007). A fragmentação da gestão educativa em EI e as dívidas do regime de colaboração efetivo entre as esferas subnacionais de governo ainda persistem, alimentadas, ademais, pela convivência ambígua entre políticas sociais e neoliberais.

e) O município, como esfera autônoma, constitucionalmente descentralizada e partícipe da construção de uma EI contextualizada segundo as últimas normativas de qualidade, deve assumir a responsabilidade de manter os compromissos de oferta e qualidade educativa segundo as orientações nacionais. Isso tem permitido, em alguns casos, o fortalecimento do trabalho interno das equipes de gestão educativa, algumas alcançando claro destaque ao longo do tempo pelas suas estratégias de ação e influência no contexto. Não obstante, destacam-se as diferenças entre municípios 
manifestada nas pesquisas nacionais, um cenário que, mesmo permitindo a contextualização das práticas e da variabilidade regional, também deixa de manifesto as deficiências de gestão que persistem em alguns locais e pouca intervenção do Estado - além do econômico - para resolver a situação. Assim, é possível perceber uma fragmentação não apenas entre as esferas Federal, Estadual e Municipal, se não também entre municípios. Daí que adquiriria sentido a demanda de maior responsabilização do Estado e de toda a sociedade civil na Educação Infantil brasileira.

f) A qualidade da EI, definida como construção participativa e democrática, encontrase ainda em processo de efetivação, na medida em que os processos de implementação de políticas públicas permaneçam como problemas cruciais na educação de infância e incorram em profundas desigualdades no país. Como configurar um sistema de educação de infância a partir da multiplicidade brasileira sem que esteja entrecruzado por estratificação social e econômica? Como garantir qualidade que respeite as diferenças e que, ao mesmo tempo respeite os direitos universais de todas as crianças? Como envolver ao Estado no fortalecimento do trabalho interno das redes sem cair na padronização do sistema? São as perguntas da sociedade brasileira em torno da EI, de suas políticas e legislações. As respostas, sem dúvida, repercutirão nas próximas escolhas e nos rumos da configuração do contexto como fator de qualidade da Educação Infantil. 


\section{EDUCAÇÃO INFANTIL NO CHILE E NO BRASIL EM BUSCA DE QUALIDADE: LINHAS DE TEORIZAÇÃO}

Os contextos chileno e brasileiro na configuração das políticas públicas de Educação Infantil guardam uma série de semelhanças e algumas significativas diferenças.

Antes de iniciar o trabalho de comparação, é importante esclarecer que, no Chile e no Brasil, a educação pública das crianças menores de 6 anos ocorre em três instâncias ou "fazeres" específicos que, embora interligados, atuam de maneira diferente na construção da Educação Infantil. Uma instância refere-se ao processo de planejamento e à produção de políticas nacionais. Outra, à gestão do sistema dentro de uma estrutura de poder público representada na comunidade por uma entidade com status no organograma políticoadministrativo (município), e uma terceira instância in loco, que se evidencia na relação adulto-criança, compondo o espaço físico e humano das creches e pré-escolas.

Um dos focos deste estudo, como dito, foi conhecer a configuração das políticas de EI no Chile e no Brasil, priorizando a intersecção das duas primeiras instâncias na busca de qualidade de Educação Infantil, as quais se refletem na forma que cada sociedade tem assumido concepções e tem organizado suas estruturas e legislações coerentemente com os sistemas descentralizados de educação e com os modelos de responsabilização educativa adotados. Neste capítulo, se realiza o exercício de comparação sendo identificadas as conexões entre a configuração de políticas públicas que subsidiam a representação de Educação Infantil de qualidade do Chile e do Brasil, pontos de similaridade e discrepância entre os dois países, a partir de uma análise baseada em três linhas de teorização: fundamentos de descentralização da Educação Infantil, princípios atuais de qualidade e modelos de responsabilização educativa.

Primeiramente, considera-se fundamental começar essa discussão evidenciando os principais indicadores econômicos, geopolíticos e educacionais. Chile e Brasil são dois países de América do Sul, localizados a 3.084,19 quilômetros de distância. Os seguintes dados podem facilitar a clareza do panorama frente a questões emergentes que possam se apresentar no resto do texto. 
Tabela 13- Indicadores econômicos, sociais e demográficos, Brasil e Chile (2014)

\begin{tabular}{|c|c|c|}
\hline & Brasil & $\star \quad$ Chile \\
\hline Nome oficial & $\begin{array}{c}\text { República Federativa do } \\
\text { Brasil }\end{array}$ & República de Chile \\
\hline Renda Per Capita & US\$ 11,670 & US\$14,528 \\
\hline IDH & 0,744 & 0,822 \\
\hline PIB & US\$ 2,346 bilhões & US\$ 258,1 mil milhões \\
\hline GINI & 52,9 & 50,5 \\
\hline População & 206,1 milhões & 17, 76 milhões \\
\hline Área territorial & $8.515 .767,049 \mathrm{~km} 2$ & $2.006 .626 \mathrm{~km} 2$ \\
\hline Densidade demográfica & 23,8 hab./km2 & $23,6 \mathrm{hab} . / \mathrm{km} 2$ \\
\hline Expectativa de vida & 74,9 anos & 79,6 anos \\
\hline $\begin{array}{l}\text { Organização } \\
\text { administrativa }\end{array}$ & $\begin{array}{l}\text { República Federal } \\
27 \text { unidades federativas, } \\
\text { sendo } 26 \text { estados e um } \\
\text { distrito federal (Brasília). } \\
\text { Cada estado está divido em } \\
\text { municípios. Hoje são } 5570 \\
\text { municípios em todo o Brasil. }\end{array}$ & $\begin{array}{l}\text { Estado Unitário } \\
15 \text { regiões, sendo } 14 \text { com capitais } \\
\text { provinciais e uma região } \\
\text { Metropolitana (Santiago). Cada } \\
\text { região está divida em municípios. } \\
\text { Atualmente, o Chile tem } 345 \\
\text { municípios. }\end{array}$ \\
\hline
\end{tabular}

Fonte: Elaboração própria a partir dos dados do Ministério da Fazenda, do Banco Mundial e de indicadores macroeconômicos dos países respetivos. Ano 2014. 
Tabela 14 - Panorama geral dos níveis educacionais, Brasil e Chile (2016)

\begin{tabular}{|c|c|}
\hline Brasil & Chile \\
\hline $\begin{array}{l}\text { Educação Infantil, dividida em: } \\
\text { a)Creche (idades de } 0 \text { a } 3 \text { anos } 11 \text { meses), não } \\
\text { obrigatória. } \\
\text { b)Pré-escola (idades de } 4 \text { a } 6 \text { anos), obrigatória } \\
\text { desde 2016, a partir da EC 59/2009. }\end{array}$ & $\begin{array}{l}\text { Educação Parvularia, atende criancas entre } 84 \\
\text { dias e } 6 \text { anos, dividida em: } \\
\text { a)Sala Cuna ( } 84 \text { dias, ou finalização da licença } \\
\text { de maternidade a } 2 \text { anos) não obrigatoria; } \\
\text { b)Médio (de } 2 \text { a } 4 \text { anos) não obrigatório; } \\
\text { c)Transicão (de } 4 \text { a } 6 \text { anos), dividido em Primer } \\
\text { Nível ou Prekinder (de } 4 \text { a } 5 \text { anos) e Segundo } \\
\text { Nível ou Kinder (de } 5 \text { a } 6 \text { anos), este último } \\
\text { obrigatório desde } 2013 \text {. }\end{array}$ \\
\hline $\begin{array}{l}\text { Ensino Fundamental, obrigatório, de nove anos } \\
\text { (ciclos I e II), para crianças com idades de } 6 \text { a } \\
14 \text { anos. Lei no } 11.274 \text { de 06/02/2006. }\end{array}$ & $\begin{array}{l}\text { Educação Básica, obrigatória, de seis anos, } \\
\text { segundo o artigo } 25 \text { da Lei no } 20.370 \text {, } \\
\text { reformulada e sancionada em } 2009 \text {. }\end{array}$ \\
\hline $\begin{array}{l}\text { Ensino Médio, obrigatório, de três anos, regular } \\
\text { ou profissionalizante, para adolescentes com } \\
\text { idade de } 15 \text { a } 17 \text { anos. }\end{array}$ & $\begin{array}{l}\text { Educação Média, obrigatória, de seis anos, } \\
\text { sendo os quatro primeiros de formação geral e } \\
\text { os dois finais de formação diferenciada } \\
\text { (Científico, Humanista ou Técnico } \\
\text { Profissional). }\end{array}$ \\
\hline Educação Superior & $\begin{array}{l}\text { Educação Superior: } \\
\text { Técnico Profissional ou Universitária. }\end{array}$ \\
\hline
\end{tabular}

Fonte: Ministérios de Educação dos países respetivos.

Se considerarmos a Educação Infantil dos dois países explorada em separado no primeiro capítulo, podemos identificar que, tanto no Chile como no Brasil, a configuração de políticas públicas tem experimentado contínuas mudanças decorrentes de ditaduras, reformulações políticas, econômicas, sociais e culturais que, ao mesmo tempo, provocaram transformações e novas concepções sobre educação coletiva de crianças de 0 a 6 anos, caracterizada pela busca constante de respostas aos diferentes processos históricos, como aos avanços nas pesquisas e práticas sobre cuidado, desenvolvimento e Educação Infantil de qualidade em creches e pré-escolas.

Em relação às primeiras similitudes nos avanços políticos e legais, é possível salientar que eles têm ocorrido em ambos os países sob três características interligadas: i) o entendimento da EI como estratégia de superação da pobreza das camadas populares da sociedade; ii) a crescente importância dada pelos governos à expansão de instituições e centros destinados a creche e pré-escola; e iii) os discursos das políticas fundamentados em perspectivas muitas vezes contrapostas entre "direito v/s necessidade". 
Tabela 15- Evolução da taxa de cobertura de EI (\%) Brasil e Chile, por faixa etária anos escolhidos

\begin{tabular}{|l|c|c|c|c|c|c|c|}
\hline & $\begin{array}{c}\text { Faixa } \\
\text { Etária }\end{array}$ & 1992 & 1996 & 2001 & 2005 & 2009 & 2013 \\
\hline \multirow{2}{*}{ Brasil } & $0-3$ à & 3,3 & 8,4 & 12,0 & 14,5 & 20,3 & 24,9 \\
\cline { 2 - 8 } & $4-5$ à & 12,9 & 48,4 & 60,7 & 67,6 & 79,1 & 85,9 \\
\hline \multirow{2}{*}{ Chile } & $0-3$ à & 6,7 & 9,2 & 12,3 & 14,7 & 19,2 & 28,4 \\
\cline { 2 - 8 } & $4-5$ à & 42,1 & 49,4 & 57,5 & 68,1 & 74,1 & 87,4 \\
\hline
\end{tabular}

Fonte: Brasil - Elaboração própria a partir dos dados do IBGE/Pnad - e do relatório Todos Pela Educação 2012. Notas: As estimativas levam em consideração a idade em anos completos em 30 de junho, ou idade escolar.

Chile - Elaboração própria baseada na informação da frequência de crianças em instituições de EI do Ministério de Desenvolvimento Social, Encuesta CASEN (Pesquisa de Caracterização Socioeconômica Nacional), anos respectivos. Se integram instituições das redes JUNJI, INTEGRA, municípios, particulares subvencionados e creches VTF)

A valoração das três características supracitadas é evidenciada nos indicadores de expansão de cada país ao longo do tempo e obedece, em grande parte, à influência constante das agências multilaterais que subsidiam programas para a infância, principalmente Banco Mundial, UNESCO e UNICEF. Observa-se, em ambos os países, uma marcada presença do Banco Mundial na formulação de políticas e no gerenciamento econômico de diversos programas de investimento. Assim, o objetivo de expansão nesses países esteve ligado à urgência de centros de atendimentos para crianças "em situação de risco", justificado econômica e cientificamente na importância de programas de desenvolvimento infantil nos primeiros anos para, dessa maneira, assegurar o sucesso produtivo da criança na vida adulta. A partir desse referencial, o Banco retoma, para a Educação Infantil, os modelos propugnados por UNESCO e UNICEF, apropriando-se do discurso de que investir em EI oferece oportunidades para o indivíduo posteriormente, orientações que nortearam a produção de documentos, políticas e legislações dos países em questão, muitas vezes impondo diretrizes sobre assuntos e temáticas que os países não conseguem resolver pelas próprias condições econômicas e organizacionais. De fato, tal como foi apresentado, a urgência de expansão provocou, em alguns casos, a implementação de programas de baixo custo e, assim, de estabelecimentos sem a necessária estrutura física ou profissional, que receberam grande número de crianças.

Nas décadas de 1990 e 2000, embora a maioria das políticas pareçam fundamentar-se no direito da criança e da família, quando o alvo é a focalização na população pobre, 
provocam o efeito contrário ao aparentemente proposto, o que acaba por reforçar a convivência de políticas de assistência focalizada e políticas educacionais universais, categorias diferenciadas de atendimento, e a permanência da segmentação e desigualdade social, que deixam o respeito aos direitos da criança claramente comprometido. Esse paradoxo pode ser complementado com as ideias de Jonsson, citado por Rossetti-Ferreira (2002), que salienta tais contradições ao analisar os principais programas formais e informais de EI na América Latina, planejados pela ação do Estado mas implementados por esferas descentralizadas do poder público, grupos comunitários, instituições privadas e/ou fundações. É manifestado no texto que a maioria das políticas são justificadas como meio de intervenção social frente à necessidade de proteger a sociedade dos efeitos da pobreza e de prevenir o fraco desempenho escolar posterior das crianças através do suposto aprimoramento da escolarização nos primeiros anos. É muito interessante constatar, no caso do Brasil e no do Chile, aquilo que os autores supracitados indicam, ao confirmar que as políticas, principalmente as que visam à expansão, "procuram situar-se numa perspectiva de direitos, enquanto o discurso e documentos do Banco Mundial, em regra, os atrelam mais a uma perspectiva de necessidades" (IBIDEM, p. 90).

Concomitantemente, desde o plano global, as estatísticas expostas ao longo deste trabalho revelam que os avanços social e econômico do Brasil e do Chile em EI, associados ao propósito de expansão, podem ser avaliados positivamente no contexto latino-americano em relação aos indicadores das agências multilaterais. Relatórios da UNICEF, OCDE e PNUD revelam incremento nas taxas de matrícula, aumento do número de estabelecimentos de educação de crianças de 0 a 6 anos e redução das taxas de analfabetismo. A integração da EI ao sistema de educação formal, inclusive ampliando a obrigatoriedade dos últimos níveis, é resgatada como importante iniciativa, a qual sustenta o incremento do gasto público e o investimento nessa etapa. Dessa maneira, fica a impressão de que, nos últimos vinte anos, o empenho dos governos, a partir dos compromissos formalizados internacionalmente, centrou-se em mostrar resultados positivos da expansão e implementar políticas que tenham favorecido essa tarefa, sem entrar em detalhes sobre as condições de infraestrutura e funcionamento da gestão. 
Gráfico 16 -Taxa de cobertura de "escolarização" em EI de crianças de 2 a 5 anos, segundo indicadores OCDE 2014

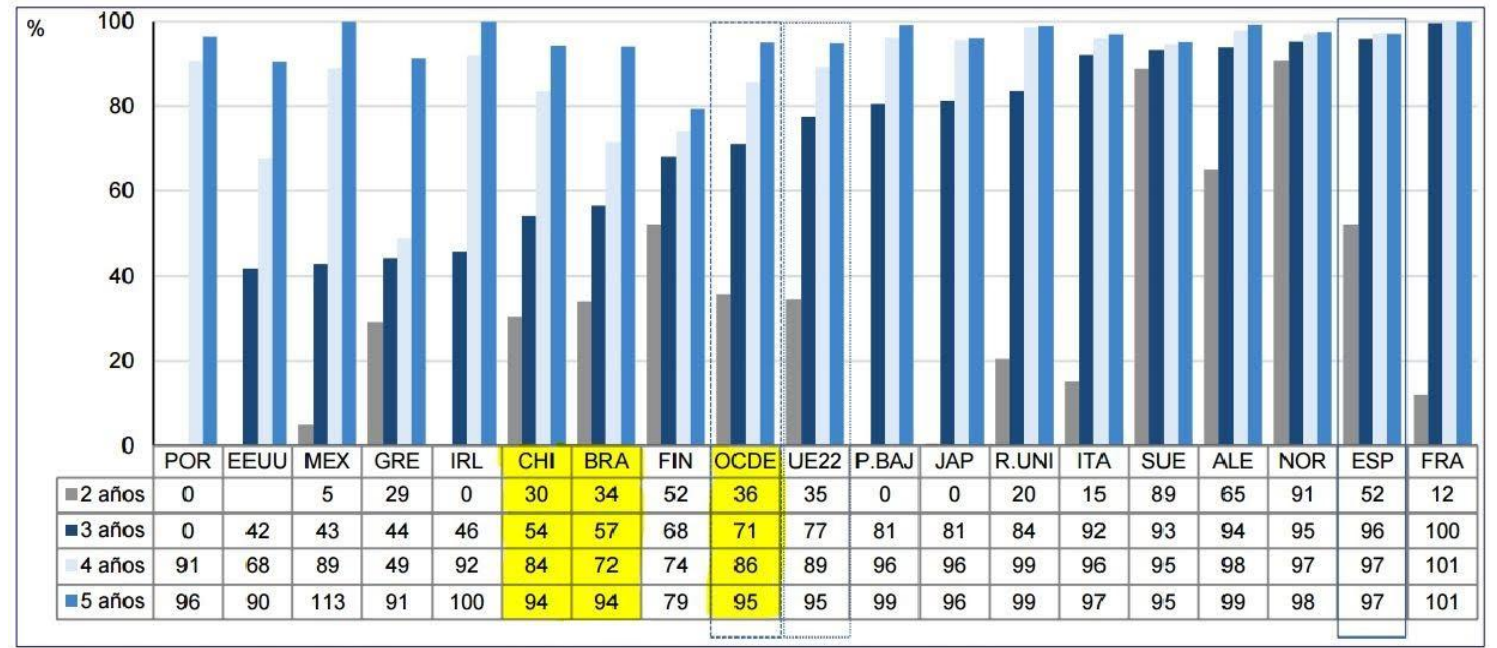

Fonte: OECD Indicators - Education at a Glance (2014).

Reforçando o que foi dito por Myers, citado por Rossetti-Ferreira (2002), os indicadores do Chile e do Brasil, dentro de América Latina, são apresentados como melhoria, embora seja importante considerar que esses índices devem ser vistos com cautela na hora da sua compreensão. A política educacional que visa ao rápido crescimento dos índices encobre, em vários casos, a prioridade dos resultados quantitativos em detrimento da qualidade dos mesmos (ROSEMBERG, 1999). Nesse sentido, comparar os dados estatísticos de ambos os países se torna um exercício bastante complexo, não só pela dificuldade de sistematizar esses dados, mas também porque não se pode considerar somente a ótica do aumento de vagas, mas as diferenciações internas e dinâmicas decorrentes dessa expansão.

Aqui ganha sentido a exploração detalhada do Brasil e do Chile realizada anteriormente junto com a sustentação metodológica desta dissertação. Ela permite ir além dos dados quantitativos para compreender as dinâmicas de ambos os países, influenciadas tanto pelo plano transnacional quanto pelos mecanismos estruturais da gestão nacional e da organização do Estado, para estabelecer mais similitudes e diferenças na configuração das políticas públicas de EI de ambos os contextos. Retomando, isso se faz a partir de três linhas de teorização: fundamentos de descentralização da Educação Infantil, princípios atuais de qualidade de EI e modelos de responsabilização educativa. 


\subsection{Educação Infantil chilena e brasileira frente aos fundamentos de descentralização educativa}

Os dois países estudados apresentam sistemas educativos nomeados pelos próprios governos como descentralizados, nos quais o município figura como importante agente de gestão. Porém, é importante discutir e elucidar as concepções de descentralização, municipalização, autonomia e participação, para compreender como se articulam no cenário de cada nação.

Na década de 1990, diante da globalização da economia e da ideia hegemônica de que o Estado, principalmente nos países subdesenvolvidos, devia desregular a sua economia tendo por base critérios negociados com organismos internacionais ${ }^{41}$, surgiu, tanto no Brasil como no Chile, um novo repertório de valores estruturais e econômicos, tais como a privatização, a abertura de mercados, a oferta e a demanda, a produtividade, a eficiência, a avaliação de rendimento, entre outros, valores que ultrapassaram ao âmbito educativo através de estratégias de descentralização com a intenção de flexibilizar a gestão educacional.

Neste sentido, a descentralização aparece em alguns sistemas educativos latinoamericanos como uma medida necessária para repensar as reformas da educação pública, tanto nos aspectos organizacionais quanto administrativos, sendo, inclusive, determinante para melhorar a qualidade da Educação. A descentralização também supôs, na maioria dos casos, a redução da ação do Estado e a transferência de atribuições para níveis governamentais específicos, através do mecanismo nomeado como Municipalização, entendida tanto como articulação da prefeitura municipal e da sociedade civil para a efetivação dos serviços como também pelo que Lobo denomina de "prefeiturização", quando a administração municipal assume a exclusividade da oferta dos serviços (LOBO, 1990, p. 7 $8)$.

Não obstante, é importante distinguir duas lógicas no processo: a descentralização administrativa e a descentralização política, as quais se configuram em cada país de maneira distinta. Bobbio explicita que:

\footnotetext{
${ }^{41}$ Cabe lembrar que as diretrizes que orientaram a descentralização são claramente defendidas por organismos internacionais já citados no percurso deste trabalho como o FMI, as agencias do Banco Mundial - Banco Interamericano de Desenvolvimento (BID) e Banco Internacional para a Reconstrução e o Desenvolvimento (BIRD) -, a UNESCO e a Organização para a Cooperação e Desenvolvimento Econômico (OCDE), o Fundo das Nações Unidas para a Infância (UNICEF), o Programa das Nações Unidas para o Desenvolvimento (PNUD), entre outras.
} 


\begin{abstract}
A descentralização política distingue-se da administrativa, não apenas pelo tipo diferente de funções exercidas, mas também pelo "título" que caracteriza o seu fundamento. A descentralização política expressa uma ideia de direito autônomo, enquanto na descentralização administrativa especifica-se um fenômeno de derivação dos poderes administrativos que, por sua vez, derivam do aparelho político-administrativo do Estado (BOBBIO, 2009, p. 331),
\end{abstract}

Essas definições podem ser complementadas com o proposto por Filmus (1997), que também destaca na descentralização educativa duas lógicas: a economicista/tecnocrática, dirigida a otimizar a administração fiscal através da eficiência da gestão e sua relação entre custo-benefício para melhoria do bem estar social e da eficiência técnica; e a democrático/participativa, que promove a tomada de decisões e designação de recursos aos administradores escolares e comunidade educativa local, não por critérios de eficiência, mas pelas noções de compromisso e participação cidadã.

Como nos alertam Souza e Faria (2004), nessa discussão importa chamar atenção para o conceito de desconcentração que, por vezes, é identificado como sinônimo de descentralização, apesar de ter um caráter mais operacional do que político. Além disso, a desconcentração caracteriza-se pela centralização da decisão e controle de resultados, no qual o poder central estabelece as regras e promove a avaliação, deixando para as esferas subnacionais tanto a execução administrativa quanto a financeira.

Embora essas lógicas anteriormente descritas apresentem ênfases diferentes, convivem em cada sistema educativo com distintos graus de envolvimento, dependendo do modelo de estruturação do Estado. Enquanto que o Chile, constitucionalmente, estabelece-se como Estado Unitário, cuja ação só é limitada pelas fronteiras do país, o Brasil destaca-se como República Federativa, onde coexistem outros níveis de governo, com competências autônomas e complementares.

A distribuição de responsabilidades e de poder entre níveis administrativos ou governamentais, como se deduz das experiências brasileira e chilena, é determinada, em grande medida, pela forma de governo do Estado em questão, se Federativo ou Unitário. Eis aqui uma grande diferença que repercute na organização do Estado e determina a relação entre este e as esferas subnacionais, não apenas na área educativa, e sim em todas as dimensões da sociedade. Ainda que, no âmbito das reformas educacionais, a descentralização se revele de diferentes formas e com diferentes sentidos políticos, a comparação que se pretende no presente estudo enfocará a descentralização enquanto transferência dos serviços educativos "entre níveis de governo e do Estado para a sociedade civil” (LOBO, 1990, p. 7). 
Tal como foi apresentado, a Educação Infantil chilena experimentou um forte processo de descentralização de todos os níveis de educação, entre elas a EI, que se deu num cenário ditatorial, motivado pela necessidade de racionalizar recursos fiscais escassos e facilitar o controle dos estabelecimentos. A Municipalização da Educação Infantil pública não foi a única estratégia descentralizadora, pois, de forma simultânea, a privatização educacional foi também considerada legal e consentida pelo Estado. Assim, tanto a promoção da livre competência entre instituições municipais e particulares subvencionadas, como a aceitação da liberdade de escolha por parte das famílias foram características que, no plano nacional, indicaram o sucesso do processo descentralizador, mas, no plano local, a legitimaram como uma proposta apenas administrativa com orientação privatizadora. A atribuição de participação municipal esteve limitada à contratação de professores, à manutenção dos centros de atendimento e sujeita ao desenvolvimento de competências administrativas dos municípios acima das capacidades de tomada de decisões e proatividade pedagógica. A "boa gestão municipal em Educação Infantil" foi articulada nesse período a partir da consecução hierárquica de metas e da dependência financeira do município ao governo central.

Nos governos democráticos posteriores, o Chile manteve o mesmo estilo de gestão. A novidade foi a retomada de algumas funções do Estado e a preocupação em desenvolver programas de intervenção social que "normalizassem" estrutural e pedagogicamente um sistema considerado como deficiente. As medidas apontaram à distribuição igualitária do atendimento através da expansão das instituições e implementação de programas focalizados para a população mais vulnerável. Apesar desta etapa no Chile ter sido conhecida na literatura como “descentralização pedagógica” (ESPÍNOLA,1997), pois incluía medidas para melhorar as práticas pedagógicas em Educação Infantil dentro das instituições, foi observada uma forte orientação centralizadora nos documentos legais que as sustentavam. Com o objetivo de "universalizar" a Educação Infantil nos últimos vinte anos, em todas as suas dimensões, a gestão municipal chilena adquiriu validade, na medida em que demonstrou eficiência nas funções fiscalizadoras de rendimento nos centros educativos e de prestação de contas desses resultados ao Estado e às famílias, funções estas enquadradas na lógica da desconcentração e da descentralização economicista/tecnocrática.

Desta maneira, resulta evidente que a descentralização da Educação Infantil, em nível municipal no Chile, por muito tempo, não tem sido outra coisa que um processo imposto por decreto e conduzido unilateralmente pelo Estado, situação que expôs as localidades ao risco de não serem envolvidas na construção da Educação Infantil. Nesse sentido, frente à heterogeneidade de estratégias descentralizadoras, a débil participação da rede municipal 
ratificou o fato de que a educação nesta esfera funciona centralizadamente, não constituindo um fator de melhoria educativa substancial.

\begin{abstract}
“(...)efetivamente, a descentralização educativa na esfera municipal não contemplou instâncias formais de coordenação com órgãos ou outros agentes descentralizadores para gerar uma política territorial integrada à política nacional. Não obstante, acredita-se que essas limitações não devessem imobilizar, menos ante a evidência do potencial participativo e colaborativo dos territórios, capacidades essenciais para a qualidade da educação chilena, as quais não podem seguir se esquivando" (CASTRO-PAREDES, 2011, p.15 - tradução minha).
\end{abstract}

No Brasil, destaca-se uma diferença muito importante. A descentralização educativa se configurou sob uma "racionalidade democrática" (SOUZA E MACEDO, 2004) respaldada pela Constituição de 1988 e pela recuperação das bases do histórico Estado federativo, depois de 20 anos de ditadura, sendo inspirada na associação entre descentralização e democratização, na qual o município é um ente federado com autonomia de ação. A manutenção do Estado como principal provedor da educação pública no Brasil, pela Constituição e pela LDB, reforçou a tendência de responsabilizar todas as esferas de governo pela garantia da oferta e qualificação da educação. Esta concepção anunciou as possibilidades de uma gestão municipal incrementada pela descentralização democrático-participativa, na qual o munícipio tem um papel relevante nos aspectos não apenas administrativos e financeiros, mas também políticos e pedagógicos.

Com a mundialização da economia capitalista, que começou a predominar na década de 1990, a sociedade civil brasileira impulsionou o surgimento de novas demandas que consolidaram a descentralização como uma estratégia imprescindível para garantir o sucesso do sistema educativo. Organismos internacionais exprimiram a importância de mudanças políticas, econômicas, sociais e culturais na educação básica: a Declaração Mundial sobre Educação para Todos - Plano de Ação para Satisfazer as Necessidades Básicas de Aprendizagem, documento aprovado na Conferência de Jomtiem, na Tailândia (1990), afirma em seu artigo terceiro que a municipalização deve tornar-se um instrumento administrativo e político eficiente de formação como instrumento de equidade através de parcerias para facilitar a organização da educação. As indicações do Banco Mundial e do Banco Interamericano de Desenvolvimento (BID), por sua parte, reconhecem a fragmentação entre cidades, regiões e nação como parte de um processo descentralizador que reduz a ação do Estado e que poderia trazer sucesso na melhoria da qualidade educativa a partir da instrumentalização para alcançar eficiência. Neste sentido, o Brasil decide promover legislativamente a integração entre o global, o regional e o local mediante um processo 
relacional efetivado pela via educacional e pelo compromisso dos municípios com novas ações envolvendo todas as esferas de governo. Assim, frente à racionalidade financeira dos anos 1990, os municípios foram concebidos como a convergência das diretrizes econômicas nacionais e dos pressupostos de participação local.

Seguindo essa linha e de acordo com Martins (2000), a Educação Infantil brasileira, dentro do sistema educativo, já nasce numa estrutura descentralizada, que desde a origem designou a rede municipal como via de aproximação à comunidade, envolvendo ONGs, empresas, família e demais instâncias da sociedade civil local, para assumir a implementação do atendimento institucional com alto grau de autonomia administrativa, financeira e pedagógica. A legislação determina que os municípios, tendo como gestor o prefeito, uma câmara de vereadores, e, como fiscalizadores, os Conselhos Municipais, sejam encarregados, junto com os profissionais das instituições, de adequar as orientações nacionais, assim como implementar projetos educativos próprios

(...) qualquer município no Brasil pode criar, administrar e supervisionar seu sistema de Educação Infantil. Os estados não se envolvem na oferta de serviços de educação infantil, mas são responsáveis pela regulamentação e supervisão de quaisquer serviços existentes nos municípios que não implementaram seu próprio sistema. Os estados também são responsáveis por favorecer cursos de formação de professores de Educação Infantil. (BRASIL, 2012, p.46)

Dessa citação, é possível elucidar que a autonomia adquirida pelo município não é isolante do resto dos poderes públicos. De fato, Barroso define autonomia municipal como

(...) uma maneira de gerir, orientar, as diversas dependências em que os indivíduos e
os grupos se encontram no seu seio biológico ou social, de acordo com as suas
próprias leis, mas também das leis nacionais. (...) Por isso, o desenvolvimento de
uma política de reforço da autonomia mais do que "regulamentar" o seu exercício,
deve criar as condiçôes para que ela seja "construída" em cada espaço, de acordo
com as suas especificidades locais e no respeito pelos princípios e objetivos que
informam o sistema público nacional de ensino. Importa, ainda, ter presente que a
autonomia resulta, sempre, da confluência de várias lógicas e interesses (políticos,
gestionários, profissionais e pedagógicos) que é preciso saber gerir, integrar e
negociar (...) A autonomia é um campo de forças, onde se confrontam e equilibram
diferentes detentores de influência (externa e interna) dos quais se destacam: o
governo, a administração, professores, alunos, pais e outros membros da sociedade
local. (BARROSO, 2008, p. 16-17)

Já nesta vertente, Martins (2000, p. 87) argumenta que o processo de autonomia local só pode ser construído mediante o equilíbrio das diretrizes, metas e procedimentos que, necessariamente, seja por sua natureza, seja como resultado de um processo histórico de interação Estado/Sociedade, envolvem formas de articulação permanente do Estado com os diferentes atores, tanto quanto à sua formulação como executor das ações. Assim, a estrutura 
descentralizada brasileira legitima a compartimentação de funções e a democratização da EI a partir da colaboração entre as esferas envolvidas. Ou seja,

(...) A descentralização da educação nas suas vertentes administrativas, financeiras e pedagógicas ocorrerá não só como uma transferência de responsabilidade dos órgãos centrais para os locais, da União para os estados e destes para os municípios, como implicará também um movimento de repasse direto de certas obrigações de órgãos do sistema para a escola. Assim a democratização da educação será compreendida pelo Estado como uma necessidade de procurar imprimir maior racionalidade à gestão da mesma. São proposições que convergem para novos modelos de gestão do ensino público, calcados em formas mais flexíveis, participativas e descentralizadas de administração dos recursos e responsabilidades (OLIVEIRA, 2002, p. 129).

Ora, a complexidade da educação contemporânea do Brasil e sua própria estrutura descentralizada, no caso da Educação Infantil, tem sido um enorme desafio na definição dos papéis de cada instância governamental e não governamental (União, estados, municípios, comunidade escolar e local), considerando o equilíbrio entre as orientações economicistasneoliberais e aquelas que apontam para uma maior participação política do município. Tal como foi registrado no cenário brasileiro, os esforços foram postos nos princípios de Regime de Colaboração entre União-Estado-Município e na Gestão Democrática local, de modo a atender o conteúdo democrático apontado nas bases legislativas e políticas públicas. Não obstante, não é possível determinar com certeza a forma com que todos os municípios brasileiros assentaram esses fundamentos como pilares para a construção da sua Educação Infantil, nem a forma como o Estado federativo lida com cada um dos contextos. De fato, na tendência atual de apresentar a EI em nível nacional, os relatórios têm retratado profundas desigualdades decorrentes das práticas administrativas-tecnocráticas dos municípios que desconsideram as prioridades das gestões locais e a necessidade de algumas delas de contar com apoio da União muito mais do que o estritamente econômico. Aliás, Maia, Cruz e Vieira (2011) destacam que as grandes desigualdades na gestão municipal se relacionam também com resistências, valores e crenças cristalizadas no interior do sistema municipal - práticas de corrupção interna das autoridades municipais, excesso de burocracia e hierarquia institucional - que atentam contra a sua efetiva autonomia e acabam reproduzindo o município como "apêndice" de outras instâncias de poder.

Grande parte das políticas e da legislação apresentadas como evidência no cenário brasileiro salientam realidades diversas de implementação nas redes municipais e, em alguns casos, salientam a manutenção do poder decisório e fiscalizador da União e a dependência, principalmente econômica, do município, além da intensa dicotomia entre financiamento e 
gestão local, dissociados, portanto, do espírito de autonomia colaborativa que marcou os patamares legais e constitucionais.

Nessa direção, Souza e Macedo (2004) concordam:

Em grande medida, essa divisão, caracterizada pela dicotomia entre o planejar e o executar, entre o decidir e o gerir, entre o dizer e o fazer, se apresenta como expressão mesma do "velho" federalismo brasileiro, pois, fiel às tradições da cultura política do país, não logra transitar da letra jurídica das propostas às práticas político-institucionais que, em essência, a reflitam (p.33)

Tabela 17 - Evolução da taxa de Cobertura de EI por apenas dependência municipal (\%) Brasil e Chile - anos escolhidos

\begin{tabular}{|l|c|c|c|c|c|c|c|c|}
\hline & & 1990 & 1995 & 2000 & 2004 & 2008 & 2011 & 2013 \\
\hline \multirow{3}{*}{ Brasil } & creche & s/i & 62,25 & 61,66 & 61,43 & 64,78 & 63,55 & 63,17 \\
\cline { 2 - 9 } & pré-escola & s/i & 60,80 & 67,74 & 68,26 & 75,36 & 74,62 & 73,99 \\
\hline \multirow{2}{*}{ Chile } & creche & 29,23 & 27,86 & 24,66 & 20,69 & 5,37 & 3,68 & 1,57 \\
\cline { 2 - 9 } & pré-escola & 52,28 & 50,51 & 48,83 & 51,71 & 42,15 & 35,77 & 32,17 \\
\hline
\end{tabular}

Fonte: Brasil - Elaboração própria a partir dos dados do IBGE/Pnad e INEP.

Chile - Elaboração própria baseada na informação da Encuesta CASEN (Pesquisa de Caracterização Socioeconômica Nacional), anos respectivos. Integram-se apenas as instituições com dependência total municipal, e excluem-se instituições das redes JUNJI, INTEGRA, particulares subvencionados e creches VTF)

Desta maneira, esclarece-se que tanto o Brasil como o Chile possuem sistemas educativos descentralizados, surgidos em distintas circunstâncias históricas e sociais. Daí que a relevância adquirida pelas redes municipais e o alcance do trabalho com a EI, através do tempo, também apresenta marcadas diferenças. No Brasil, o município aparece como agente descentralizado assumindo os dois caráteres, tanto administrativo quanto político, pois o poder de decisão é transferido efetivamente, inclusive sobre os recursos financeiros, às esferas municipais, além de concentrar e manter, através do tempo, a maior porcentagem de atendimento. No Chile, ao contrário, a participação e a ingerência na tomada de decisões é praticamente inexistente, característica evidenciada tanto pela legislação quanto pela queda de matrículas ano a ano.

Embora seja possível perceber que, nos dois países, existe uma valorização do município como instância governamental, em termos de desconcentração e competências economicistas/tecnocráticas, decorrentes de tendências nas quais a eficiência técnica e financeira prevalece como fator de qualidade, em termos pedagógicos e políticos, o Brasil 
leva em consideração, há muito mais tempo, a autonomia democrática/participativa como patamar da descentralização, embora ainda existindo diversos conflitos na sua efetivação.

Contudo, os âmbitos político, acadêmico e social do Chile e do Brasil reconhecem as falências do próprio sistema educativo descentralizado e trabalham atualmente em políticas adequadas que favoreçam práticas de gestão democrática. No caso do Brasil, é preciso concretizar um regime de colaboração que ultrapasse o campo das intenções e defina medidas claras quanto às competências de cada ente federado e as ações de assessoria técnica e financeira aos municípios para que ousem na formulação de políticas educacionais próprias. No caso do Chile, esperam-se políticas que atinjam o atendimento de demandas locais e a valorização da história e da cultura dos municípios, além do término da concorrência com instituições com financiamento misto.

De acordo com Candia (2004, p.4)

(...) atualmente a tendência à uma maior descentralização dos sistemas educativos está acompanhada também por uma maior autonomia dos órgãos administrativos e as escolas, assim como uma maior participação da comunidade, sendo esta entre todas as tendências emergentes, a que mais otimismo tem suscitado entre os expertos educacionais da região.

Daí que ambas as sociedades manifestam a importância de gestores qualificados e comprometidos com a participação no local e mecanismos de articulação das políticas públicas nacionais que garantam a contribuição da agência local na construção da EI. Essas orientações ocupam grande parte das agendas públicas e configuram-se como importante eixo na busca de qualidade da EI, registrando-se recentemente algumas iniciativas ainda em fase de expansão ${ }^{42}$. Nesse quadro, cabe perguntar como é que este grande desafio da gestão educacional será compatível não apenas com a promoção de mudanças capazes de obedecer e se inserir nos espaços econômicos globais, mas também em assegurar as condições para que a convivência democrática possa se consolidar.

\footnotetext{
${ }^{42}$ Vale lembrar os projetos e os documentos oficiais mais recentes sobre a questão de qualidade da EI, revisados em cada cenário, como a Lei de Inclusão e Acreditação de Qualidade no Chile e os Indicadores de Qualidade no Brasil.
} 


\subsection{Educação Infantil chilena e brasileira frente aos princípios atuais de qualidade}

Ao longo dos últimos trinta anos, a atenção aos princípios de qualidade da educação e cuidado da infância são temas em constante debate pelos governos, famílias, educadores, comunidades locais e pesquisadores. Tanto o Brasil como o Chile têm configurado políticas de Educação Infantil vinculadas a um processo constante de melhoria, nas dimensões de organização institucional, financiamento, formação profissional e currículo, a maioria delas, amparadas legal e teoricamente nos direitos da criança e sentidos democráticos de implementação. Porém, e tal como foi evidenciado nos contextos brasileiro e chileno, esses processos não têm acontecido isoladamente. As dinâmicas como o neoliberalismo, a globalização e a descentralização têm repercutido, direta ou indiretamente, sobre a questão da qualidade na Educação Infantil e sobre o grau de envolvimento dos agentes responsáveis, originando um campo de disputa constante, devido, quiçá, ao pouco conhecimento e à pouca valorização do significado de qualidade, ou à complexidade teórica, operativa e prática que permita sua melhor definição. É nesta disputa, refletida também na literatura contemporânea sobre qualidade da educação, que emergem distintas concepções sobre o que esperar da EI.

Gentili (2001), a partir de uma perspectiva humanista, alerta-nos de que a educação entendida como direito só se completa com a qualidade e que, portanto, o acesso e a qualidade são um binômio inseparável e garantido como um direito humano inalienável. Moss e Dahlberg (2008), por sua parte, afirmam que grande parte da sociedade ocidental vive em uma "era da qualidade", em que cada produto e serviço deve oferece-la assim como cada consumidor pode exigi-la, tornando-se um atributo essencial, assumido como inerente e neutro.

Os dois sistemas educativos estudados não escaparam a essa crescente atenção dada à qualidade da educação, primeiro, estabelecendo-a como prioridade nos documentos oficiais, e, em seguida, desenvolvendo estratégias para sua manutenção, sua fiscalização e sua avaliação. É interessante observar que, em muitos casos, porém, a perspectiva do direito se desvanece nas políticas e nos programas que defendem a qualidade educativa, daí que, por exemplo, pensar atualmente em qualidade no ensino fundamental e no ensino médio geralmente tende a ser relacionado a "um serviço" para os alunos, caracterizado pela produção eficiente de resultados pré-definidos e normativos, associados a determinadas aprendizagens avaliadas quantitativamente, cenários que podem ser achados em ambos os países estudados e que, inclusive, sustentam reformas educativas na busca de uma melhor qualidade educativa. 
No caso da EI, a inclusão do conceito de qualidade na legislação e políticas públicas no Chile e no Brasil é recente, muito mais tardio do que nos outros níveis, e predominantemente orientado a fiscalizar e a avaliar o atendimento e o funcionamento das instituições. As primeiras iniciativas públicas dos dois países se referem ao fortalecimento da organização institucional, infraestrutura, materiais pedagógicos, razão adulto-criança, formação e aperfeiçoamento dos educadores, e disposição de recursos econômicos para uma eficiente gestão administrativa. Essas medidas demandaram o desenvolvimento e a aplicação de critérios objetivos para determinar a qualidade estrutural e organizacional das instituições, assim como a qualidade de funcionamento dos processos de implementação. Paralelamente surgiu também a preocupação por desenvolver normas e diretrizes de boas práticas e interações dentro da instituição infantil, entre os adultos e as crianças, como forma de gerar satisfatórias experiências de aprendizagem, sustentadas no direito da criança ao desenvolvimento e à aprendizagem. Fundada no conhecimento de uma "criança universal", foi promovida a distinção entre práticas adequadas e inadequadas além de uma abordagem descontextualizada definida por especialistas, majoritariamente vindos da Psicologia do Desenvolvimento, desde uma base de conhecimento racional indiscutível e mensurável, priorizando o "como" sobre "o porque".

Essa visão pré-determinada e universal da infância, bem como a correspondente padronização de processos de implementação e práticas educativas, teve e ainda tem bastante influência no planejamento e na implementação das políticas dos países em estudo. Porém, algumas teorias de alcance internacional, com bastante repercussão na Europa, têm chegado a espaços acadêmicos latino-americanos, concebendo um estilo de qualidade focalizado nos direitos da criança, mas contextualizado e distanciado tanto do modelo assistencial quanto do modelo escolar. A ideia de qualidade como algo universal e mensurável por especialistas, em contraste com a ideia de ser um conceito construído a partir de valores, subjetividades e pluralidades, tem causado discussões e interpretações nos países sobre a importância do processo de definição e implementação da qualidade da Educação Infantil, assim como a revisão das concepções historicamente adotadas.

Adquiriram assim importante relevância as problemáticas em relação à qualidade surgidas do conflito entre a propositura nacional e a local, presentes tanto no Chile como no Brasil. Segundo Moss e Dahlberg (2008), os desencontros das esferas políticas, econômicas e sociais derivam de uma permanente contradição entre a tendência a padronizar e a importância reconhecida da diversidade dos contextos em que as crianças vivem, crescem e se desenvolvem. É no âmbito deste duplo movimento de leitura e conceitualização que a 
qualidade tem sido incorporada na busca do equilíbrio tanto na legislação e nas políticas públicas como no discurso dos agentes envolvidos, sejam eles gestores, professores, pais e crianças.

A trajetória chilena mostra a reprodução dessas contradições. Embora atualmente os principais documentos reconheçam a importância dos direitos da criança e os componentes do contexto na construção de qualidade educativa, as principais legislações e políticas públicas que vigoraram nas últimas décadas não contêm uma definição clara de qualidade e ainda mantêm critérios de operacionalização focados no estrutural, instrumentalizando o conceito e legitimando-o desde a base da normalização, estabilidade e segurança, presumindo também a possibilidade de avaliação padronizada e descontextualizada.

(...) por envolver fatores observáveis e com isto, suscetíveis de ser medidos, a qualidade estrutural foi abordada por muitos países - entre eles, o Chile - como primeiro passo ao assentamento de sistemas garantia de qualidade, os quais exigiram a fixação de indicadores e formas de verificação dos mesmos (UNESCO 2005).

Clarke (1998, p.7-8), acerca dessa "operacionalização" da qualidade, também complementa

\begin{abstract}
(...) este discurso da qualidade está firmemente inserido na tradição e epistemologia do positivismo lógico, cujas principais características estão enraizadas no projeto da modernidade. O positivismo lógico é baseado em uma firme convicção de que o mundo está "lá fora" à espera de ser descoberto e descrito e apreendido ... e que é só por meio da aplicação de critérios lógicos (e empíricos) que somos capazes de distinguir o conhecimento genuíno e objetivo da mera crença.
\end{abstract}

As reformas educacionais chilenas em EI têm ganho aceitação pública pela permanência e pela promoção de indicadores universais a ser alcançados, não apenas por municípios e próprias instituições, se não também no marco da interação "in loco" adultocriança na sala de aula, reforçando assim um conceito de qualidade fundado no modelo de eficiência gerencial do Estado. As políticas de organização institucional, financiamento, currículo, formação de professores e, inclusive, aquelas políticas sociais integradas ao sistema educacional chileno, são fundamentadas em nome "da garantia de equidade" de oportunidades de acesso e direito universal de todas as crianças. Porém, com o tempo, essa universalização, sob o conceito de qualidade a partir de resultados, paradoxalmente tem refletido na estagnação da segmentação educativa e nas desigualdades entre localidades. Assim o expõe Cassassus:

Me chama poderosamente a atenção o poder desmesurado dado aos instrumentos estandardizados na avaliação e na gestão do sistema educativo quando, ao contrário do esperado, esses elementos deixam ao sistema preso numa dinâmica perniciosa em 
torno a melhorar a qualidade que, finalmente, tem como consequência o fomento da desigualdade e a diminuição da qualidade da educação porque empobrece seus alcances e expropria a vontade dos gestores de melhorar in situ.(...) Se enxergarmos os critérios estabelecidos nas políticas pelos últimos 25 anos, os mesmos resultados informam que não houve o progresso estimado, inclusive em muitos países, e o que houve foi um retrocesso em que a segmentação e desigualdade social tem sido fortalecida. Não é difícil concluir que essas reformas nunca foram políticas de educação se não que foram políticas econômicas e de gerenciamento. (CASSASSUS, 2007, p.72-73 - tradução minha)

Diante do "problema com a qualidade", a proposta atual de mudança no Chile pretende definir qualidade de EI partindo da valorização das localidades nas decisões e iniciativas, distanciando-se das abordagens positivistas de qualidade e aproximando-se de uma definição de qualidade como processo intersubjetivo e contextualizado. O conflito radica em como "reconceitualizar" a qualidade da EI chilena, considerando a diversidade, a subjetividade e as múltiplas perspectivas dos agentes envolvidos num cenário caraterizado historicamente pela rigidez e pela padronização. Cabe apontar alguns autores que podem dar pistas nessa direção.

Nas teorias de Dahlberg, Moss e Pence, no livro Beyond Quality in Early Childhood Education and Care (1999), a visão de qualidade está fundada na dinâmica participativa e democrática onde não existe definição objetiva, nem há, para defini-la, critérios universais, estabelecidos de uma vez por todas. Eles propõem que definir qualidade significa uma construção conjunta de significados, ou seja, "fazer sentido" (making sense) com os outros num determinado contexto.

Da participação, na definição de qualidade, de todas as instâncias envolvidas no cuidado e na educação da primeira infância (especialistas, gestores, profissionais, pais, etc., e até mesmo... crianças) é que dependem a pertinência e a equilibrarão dessa definição, progressiva e permanente, em razão da necessária atualização dos conhecimentos no campo da primeira infância (e além) e do ajuste constante às evoluções das realidades sociais. (DALHBERG, et al., p. 191 - tradução minha)

Essa concepção democrática de qualidade, que combina os aspectos éticos, políticos, pedagógicos e científicos, inspirada na experiência da rede Reggio Emília ${ }^{43}$ propicia um novo papel das instituições da primeira infância na construção consensual de qualidade que proporcione a reflexão e a produção coletiva de significados sobre os processos educativos desenvolvidos com e pelas crianças. Tais argumentos criticam algumas iniciativas dos

\footnotetext{
${ }^{43}$ A filosofia de Reggio Emília é uma experiência educativa que nasce em 1945 no norte da Itália, na cidade chamada Reggio Emília. Fundada por Loris Malaguzzi, é conhecida mundialmente como uma das melhores propostas educativas públicas para a primeira infância, focada nos princípios básicos de: criança como protagonista; professor competente, colaborador e guia; espaço como terceiro educador; famílias como aliados; e documentação pedagógica.
} 
governos, empreendidas em nome da garantia de qualidade e sujeitas a objetivos econômicos e de mercado por sobre os interesses educativos; pelo contrário, defende-se a construção de qualidade desde as razões e os entendimentos da própria instituição. Isso sugere, de acordo com Peralta (2002), que

(...) no fundo, a ideia central é "co-construir" os sentidos e os juízos sobre o valor de
uma experiência educacional para assim definir sua qualidade através de um
processo crítico e reflexivo com toda a comunidade educativa, que integre a busca
de sentidos básicos da proposta educativa que se deseja. Na implementação do
processo, são fundamentais a problematização, uma boa documentação pedagógica e
o diálogo. Também pode ajudar a participação de facilitadores que apoiem o grupo-
base no caminho de busca, análise e construção dentro do contexto histórico-
espacial de cada experiência. (p. 60 - tradução minha)

Vejamos, pois, o caso do Brasil. A revisão documental da configuração de políticas indica, de forma semelhante ao Chile, a preocupação pública do Estado por estabelecer medidas nacionais que assegurem a qualidade de funcionamento estrutural e organizacional, tais como o FUNDEB, os programas de formação docente continuada, a inclusão das creches ao setor educacional, as diretrizes curriculares e os critérios de funcionamento para as instituições que, da mesma forma que os programas sociais de merenda escolar e transferência de renda, envolveram a exigência de fiscalização e acompanhamento dos resultados. Rosemberg (2010) denuncia algumas dessas iniciativas, nomeando-as como "política do espetáculo", traduzidas em práticas de grande visibilidade midiática, eleitoreira, mas pouco comprometidas com a qualidade do atendimento oferecido às crianças. O problema, segundo a autora, é que políticas dessa natureza, além de ignorarem "dimensões consensuadas sobre a especificidade da Educação Infantil", como "educar e cuidar com equidade e qualidade", levam a ações que desconfiguram o caráter dos espaços destinados às crianças pequenas, marcando um cenário de avanços, mas também de inconsistências, paralelismo e descontinuidade (2010, p.180). Embora tenha sido possível evidenciar esses conflitos no cenário brasileiro, no percurso deste trabalhou observou-se também uma orientação paralela que, coerente com o processo histórico de redemocratização pós-ditadura, fez a Educação Infantil percorrer e manter outro caminho, em grande parte pela responsabilização das redes municipais e da agência dos movimentos acadêmicos e da sociedade civil em prol da defesa de princípios diferentes à qualidade com base em resultados mesuráveis, senão que adotando processos mais participativos, com maior ênfase na responsabilização dos agentes e a colaboração, mais do que na competição. Daí que, quando aparecem a definição e a conceitualização de qualidade nos documentos Parâmetros Nacionais de Qualidade para a Educação Infantil (2006) e Indicadores de qualidade na Educação Infantil (2009), estas 
parecem estar mais orientadas por pressupostos democráticos, tentando integrar, dentro de um mesmo processo nacional, princípios participativos e de auto avaliação, os mesmos defendidos pelas posições contemporâneas de origem europeia, em torno da qualidade da EI.

No Brasil, os pressupostos de Moss, Dalhberg e Pence foram representadas nos documentos oficiais para definir o conceito de qualidade e parecem ter incorporado as teorizações de Ana Bondioli, que defende a importância da participação e da autoavaliação dos protagonistas da ação educativa:

(...) A participação vai além da pura representação e implica um compartilhamento
de valores, objetivos e práticas entre todos os que agem na escola. Ou seja, a
participação é entendida como processo de negociação da reflexão e da ação, que
parte da tomada de consciência da existência de "pontos de vista" nem sempre
coincidentes, e visa ao compartilhamento, à sinergia, à elaboração de formas cada
vez mais conscientes de identidade educativa com a intenção de oferecer a
possibilidade aos protagonistas da ação educativa - professores, pais, crianças - de
fazer ouvir a própria voz, de colocar essas vozes em debate, tendo como foco o
processo formativo: dialogar e refletir juntos para chegar a compartilhar tanto
idealmente quanto operativamente o projeto educativo, crescendo em consciência e
intencionalidade (BONDIOLI, 2013, p.33)

Um dos pilares no qual se fundamenta todo o documento Indicadores é o princípio da participação, isto é, apresenta um método participativo viabilizado pela autoavaliação a ser feita pela comunidade educativa. Segundo Ribeiro (2014), a partir de reflexões que foram iniciadas na elaboração do documento, quando se procurou entender porque os indicadores que descrevem fenômenos macro não são apropriados pelos atores locais, cogitou-se, entre outros fatores, que pesquisadores e tecnocratas não observam e não interrogam a realidade escolar da mesma perspectiva que as pessoas que a vivem no cotidiano. Esse fato, aliado à complexidade de não haver um conceito único de qualidade, somado ainda ao reconhecimento da legitimidade dos pontos de vista dos agentes escolares, das comunidades e de "sua capacidade de refletir e de seu direito de participar das decisões", levaram a uma necessária busca por "métodos de avaliação que fomentem o debate coletivo e a atribuição de valor com base na negociação entre os diferentes agentes” (p.223).

Nessa busca, a autoavaliação surge não como uma forma única de avaliar a qualidade, mas como uma iniciativa para construí-la e defini-la desde dentro das instituições de Educação Infantil, podendo engendrar um potencial transformador a partir de um processo que contemple as vozes dos diferentes envolvidos no processo educativo: professoras(es), diretoras(es), funcionárias(os), familiares, pessoas da comunidade, conselheiros tutelares, possibilitando, assim, “a reflexão e a definição de um caminho próprio para aperfeiçoar o trabalho pedagógico e social das instituições" (BRASIL, 2009, p.12). 
No Brasil, a temática da aferição da qualidade por meio de processos auto avaliativos ainda é um tema recente, não amplamente disseminado e não isento de tensões. Embora o documento Indicadores se apresente como um instrumento flexível, com varias formas de uso e, inclusive, com a "não obrigatoriedade" dos agentes para aplicar o processo nos centros educativos, o certo é que, para quem decide implementa-lo, o documento apresenta uma meticulosa forma de aplicação através da atribuição de cores segundo a gestão de cada centro. De fato, sem querer retirar o mérito da iniciativa, é importante lembrar que num país marcado pelas diferencias sociais, onde a preocupação pela desigualdade da EI é retratada uma e outra vez a partir de pesquisas nacionais ${ }^{44}$, a autoavaliação também implica uma complexa imbricação de poderes que podem revelar por um lado desejos de melhoria e trabalho em conjunto, mas também coações, legitimações de processos autoritários e encobrimentos burocráticos em vários níveis (RIBEIRO, 2016), dai a importância de ter clareza do instrumento e de suas limitações.

No entanto, estudos como o de Ribeiro (2016) alertam que não é possível considerar as cores e indicadores como único elemento a nos fornecer informações do contexto; é preciso casar essa pratica com outras que complementem o olhar sem, no entanto, deslegitimar o olhar dos atores que estão atuando dia a dia. A pesquisa coordenada por Campos (2015, p.36), nesse sentido, destaca que

\footnotetext{
(...) uma possível conclusão é que, para obter melhorias de qualidade, seria necessário um monitoramento externo e uma assistência pedagógica que apoiassem as equipes no exame de suas práticas de forma mais sistemática e as ajudassem a encontrar caminhos para superar as deficiências constatadas. Parece que, se a autoavaliação é uma importante etapa nessa direção, ainda assim, avaliações externas são necessárias para indicar pontos críticos nas rotinas e práticas adotadas no trabalho cotidiano com as crianças.
}

A ideia de maior fiscalização externa está adquirindo bastante legitimidade em nível nacional, ligada uma crescente linha de pensamento que sugere que maior interferência, avaliação institucional externa e universalização de indicadores por parte do Estado poderiam corrigir as deficiências na qualidade de gestão municipal, mesmo com uma minoria da população que rejeita qualquer avaliação externa e acredita que a melhoria da qualidade continua sendo resultante do apoio interno das equipes sobre as próprias práticas no trabalho com crianças pequenas.

É claro que a autoavaliação é um avanço oficial na consideração do contexto local na construção de qualidade da EI, mas é preciso ainda ponderar se essa alternativa sozinha dá

\footnotetext{
${ }^{44}$ Algumas delas citadas neste trabalho.
} 
conta do processo de avaliação da qualidade ou necessita ser complementada com outras modalidades avaliativas que levem "à percepção das verdadeiras implicações que podem prejudicar ou condicionar o processo de construção no que diz respeito à definição da qualidade num determinado contexto" (BONDIOLI, 2013, p.3).

Atualmente, o Chile e o Brasil reconhecem que, para alcançar os objetivos de qualidade, é preciso um constante equilíbrio entre os acordos nacionais e as particularidades de cada contexto. É na busca do equilíbrio que aparece o município como eixo de qualidade em ambos os países, mas, a partir de um cenário diferente e até inverso: enquanto o Chile requer se desprender de um Estado altamente centralizado e promover mais responsabilidade e participação local, para, dessa maneira, configurar o município como participante democrático da gestão, o Brasil, mesmo que ainda em discussão, tende a precisar de um Estado mais presente e colaborativo com as redes municipais. Essa perspectiva sugere uma rota interessante de análise, porque não se trata apenas de enfrentar dois contextos que parecem contrários: trata-se de que ambas as sociedades têm apostado em uma espécie de "negociação" em prol da garantia de direitos educacionais para todas as crianças e no respeito às diferenças, mas sem abrir mão de aspectos acordados histórica e internacionalmente como irrevogáveis para uma Educação Infantil de qualidade.

\subsection{Educação de infância chilena e brasileira frente aos modelos da responsabilização educativa para a qualificação da Educação Infantil}

Tal como foi apresentado, os atuais desafios da configuração das políticas públicas no Chile e no Brasil pretendem melhorar a qualidade da Educação Infantil a partir da confluência de duas posturas aparentemente contrárias, isto é, por um lado reconhecendo a qualidade como conceito que se constrói no contexto local e, por outro, exigindo do Estado a garantia do direito universal das crianças a acessar e a receber educação dentro de diretrizes acordadas nacional e internacionalmente. Tentando atingir esses objetivos, as políticas têm visado responsabilizar os agentes educativos, de acordo com os sistemas de descentralização da educação e envolvendo ao Estado, as esferas subnacionais, as instituições, a família e a comunidade em geral, com distintos ritmos, intensidades e matizes, sendo, em alguns casos, chamadas de "políticas de garantia de qualidade", "políticas de accountability", "reformas baseadas em standards", "políticas de responsabilização", "nova gestão pública" ou "sistema de asseguramento da qualidade". 
O termo accountability é recente em América do Sul. Sua tradução literal é "prestar contas", mas, nas línguas latinas, também tem sido traduzida como "responsabilização". O accountability apareceu, como conceito, inicialmente no âmbito financeiro remetendo à necessidade de outorgar responsabilidades pelas ações próprias e dar conta dos resultados da distribuição de dinheiros, informando aos clientes sobre os movimentos de recursos e sobre como esses eram utilizados (PURYEAR, 2006). No campo da educação, o conceito alude a dois sentidos: i) à "prestação de contas" dos resultados e dos processos educativos aos diferentes agentes involucrados; e ii) da "responsabilização" destes sobre tal processo.

\title{
Corvalán complementa
}

\begin{abstract}
Em primeiro lugar, a prestação de contas se refere ao processo onde os atores informam e/ou exigem informação pelo uso dos recursos para a consecução de um objetivo. Essa prestação nem sempre aponta para o financeiro, as também para o conjunto de meios (humanos, simbólicos, materiais, entre outros), ordenados de uma maneira concordante ao logro do objetivo em questão. (CORVALAN, 2006, p.10 tradução minha)
\end{abstract}

Nessa direção, tanto a prestação de contas como a responsabilização se perfilam como sentidos inseparáveis. O fato de prestar contas ou exigir a prestação de contas implica em si mesmo assumir ou demandar responsabilidades. Por sua vez, a responsabilização implica dar conta dos avanços e resultados do objetivo em comum. Dada essa indissolubilidade, Falabella \& Opazo (2014) explicam que, no planejamento de políticas públicas contemporâneas em educação, a responsabilização educativa pode se articular a partir de três orientações $\operatorname{distintas}^{45}$ :

i) Responsabilização Estatal: Ligada ao "Estado de Bem-Estar" predominante entre os anos 1940 e 1980 e vigente atualmente nos sistemas escolares de países como França, Itália e Portugal, sendo orientada pelos princípios de igualdade e pelo direito do sujeito a serviços sociais universais. Sob esse estilo de responsabilização, os agentes educativos devem garantir e assegurar o direito à educação através de medidas de incremento de cobertura, implementação de um currículo nacional e aplicação de normativas a todos os estabelecimentos por igual. Isso implica que as instituições são parte de uma estratégia educativa mais ampla, correspondente a um projeto específico de educação pública. Os educadores e os centros devem prestar contas pela adequada implementação das normativas nacionais, prescritas e administradas por níveis de governo superiores.

\footnotetext{
45 Para aprofundar-se nesses aspectos, ver: Carrasco, Falabella, Seppänen (2014); Daring-Hammond (1994); Hargreaves y Shirley (2012).
} 
ii) Responsabilização com altas consequências: Este aspecto começou a ser gradualmente observado nos anos 1980, desenvolvido nos sistemas escolares de países como Inglaterra, Estados Unidos e Nova Zelândia. Nele, os estabelecimentos são avaliados pelo seu desempenho, medido principalmente por provas padronizadas. A prestação de contas por desempenho implica uma dupla finalidade referida a um "accountability de mercado" e a um "accountability de desempenho ou performativo", em que os centros educativos e os órgãos intermediários como o município conta com as famílias, porque se espera que elas sejam também reguladoras da qualidade do sistema educativo, fundamentando assim o seu "poder de cliente". Por outra parte, o Estado define objetivos, entrega recursos, avalia e controla o desempenho de estabelecimentos e municípios "presenteando-os" com bônus por metas atingidas. Dessa maneira, as políticas de aferição de qualidade e publicação de resultados permitem o controle e a regulação desde o Estado, que, por sua vez, constitui um dispositivo de informação do mercado escolar como matriz de comparação e concorrência entre organismos por um melhor desempenho.

iii) Responsabilização Profissional: Esse tipo de responsabilização envolve regulações do Estado relacionadas com a formação docente, suas condições de trabalho e as da educação pública; identificado nos sistemas escolares de países nórdicos, como a Finlândia, além de Canadá, Escócia e Bélgica. Aponta que a equipe escolar se responsabiliza pelas experiências de aprendizagem de qualidade, o que depende em grande parte do desenvolvimento sustentado das capacidades profissionais dentro das instituições de poder. As políticas priorizam a obtenção de altos padrões profissionais na formação docente, a formação do estudante de pedagogia, junto com um alto status social da profissão e condições laborais atrativas, que se combinam com a confiança nos órgãos intermediários e nos centros de ensino, além de flexibilidade curricular e apoio estável do Estado através do governo local, que promove o trabalho colaborativo entre docentes, bem como a "autoavaliação de aprendizagem".

Para os dois países em estudo, resultou imprescindível no planejamento de políticas de qualidade da EI, a determinação de quem assumirá certas responsabilidades. Os modelos referidos acima variam segundo a ênfase de responsabilização educativa adotado por cada país e variam também de acordo com o enfoque pedagógico-curricular, as estratégias de implementação descentralizada e o envolvimento das distintas esferas de governo e agentes educativos.

No Chile, é possível constatar que, desde 1980, a responsabilização pelo atendimento das crianças tem mantido muitos elementos do modelo de "Altas Consequências", 
principalmente pelo caráter mercantil da educação chilena e pela incorporação da EI a sistemas de prestação de contas por desempenho, em que os municípios e estabelecimentos devem informar avanços e resultados às famílias e aos órgãos do MINEDUC - no caso, de pré-escolas - ou JUNJI - no caso, das creches-. Embora na metade da década dos anos 1990, tenha se observado esforço para formular uma política de Educação Infantil com elementos da ênfase de "Responsabilização Estatal", fazendo do Estado o maior responsável pela oferta, provisão e regulação de normativas nacionais, isso não significou o desaparecimento completo do sistema de altas consequências como forma de responsabilização pela Educação Infantil. De fato, e tal como foi registrado, ambos os modelos tiveram pontos de desencontro explícitos nas políticas e nos documentos legais, assim como nas práticas administrativas e pedagógicas nos municípios e instituições.

A atual Ley de Inclusión e a Ley del Sistema Nacional de Aseguramiento de la Calidad de la Educación Parvularia, Básica y Media assinalam que, frente ao fracasso do "experimento chileno" que permitiu a convivência desregulada de dois tipos de responsabilização, a mudança deve apostar na erradicação do lucro nas instituições particulares subvencionadas e o fim do controle do Estado, de maneira que as esferas locais de governo e aos agentes educativos da comunidade também possam assumir ação e responsabilização ativa do processo.

No Brasil, embora desde a década de 1990 seja estabelecido que a principal responsabilidade pela EI é do município e de seus centros educativos, observa-se a presença constante da União no planejamento de políticas nacionais e na tentativa de fiscalizar os resultados das implementações, colocando os municípios muitas vezes na posição de "dependentes", sobretudo no que diz respeito a financiamento e desempenho. A atual política de qualidade promove um ciclo de melhoria institucional e a participação democrática da comunidade educativa nos processos de implementação e seguimento dos indicadores de qualidade, permitindo, assim, que seja uma ferramenta flexível, dinâmica e voluntária. Observa-se no modelo, a inclinação à orientação de "Responsabilização Profissional", que legitima que cada equipe da instituição possa ser partícipe da consecução dos indicadores desprendidos dos parâmetros. Coerente com a estrutura descentralizada brasileira, pretende acentuar a confiança nas capacidades dos profissionais tanto dentro da instituição como dos órgãos intermediários, os municípios e centros, na construção de EI de qualidade. As políticas promovem o trabalho colaborativo e a flexibilidade do processo sempre sob senso comum de qualidade estabelecido em nível nacional. 
Semelhante ao chileno, o modelo de responsabilização educativa brasileira não consegue se encaixar apenas num aspecto e compartilha características, seja porque apenas um estilo de responsabilização não é suficiente para o avanço e a garantia da qualidade da EI, seja porque existem pendências no aperfeiçoamento de todas as características que definem cada estilo. No Brasil, a Responsabilização Profissional como eixo de qualidade na EI deixou em evidência o débil e tardio investimento na formação e no status dos profissionais envolvidos, que contrastam com as verdadeiras capacidades que precisam ter para responsabilizar-se nesse modelo. Por outro lado, e tal como foi comentado, as iniciativas de caráter nacional que exigem uma maior interferência do Estado na Educação Infantil, tanto nas avaliações e acompanhamento externo das políticas implementadas, assim como também o estabelecimento de dinâmicas que apostam por universalizar e unificar critérios como a Base Curricular Comum, que ainda se encontra em debate, faz supor que existe a intenção de incorporar algumas orientações da orientação de Responsabilização Estatal.

Contudo, a partir do olhar histórico de ambas as sociedades, constata-se como as políticas públicas fomentam a responsabilização educativa do Estado e das outras esferas de governo - municípios e instituições - na Educação Infantil de qualidade. Resulta evidente que o interesse por inserir políticas de responsabilização tem sido um tema compatível e necessário para os processos de reformas educativas na Educação Infantil brasileira e chilena, de acordo com as exigências de qualidade da cidadania e dos responsáveis de gestão, administração e práticas pedagógicas. A perspectiva adotada nesta pesquisa nasce da trajetória e do entendimento de que, embora o ponto de surgimento da configuração e processo de implementação das políticas brasileiras e chilenas por bastante tempo tenha sido distinto e inclusive oposto, o certo é que atualmente os dois países trabalham por conseguir o equilíbrio estrutural e organizacional a partir de uma espécie de "responsabilização mista" entre as autonomias locais e as regulações do Estado. Perfila-se um discurso eclético que concebe a educação como tarefa que compete "à sociedade no seu conjunto" e defende o valor da autonomia, participação e a manutenção da descentralização do sistema educativo, assim como um Estado ativo que oriente e apoie aos municípios e centros educativos na construção da educação de qualidade. Isso porque a persistência das desigualdades evidenciou, em ambos os países, que, por um lado, um sistema fortemente padronizado não pode ser bem-sucedido sem considerar os fatores do contexto local nem as decisões e contribuições dos gestores e profissionais in situ; e, por outro, que a relativização das práticas administrativas e pedagógicas podem trazer riscos na garantia dos direitos à educação e nos cuidados com todas as crianças. 
Estas afirmações se complementam com a postura de Helen Penn (2011), que reconhece que o contexto local é importante na conceitualização da qualidade, mas também que o Estado é responsável pela garantia de qualidade em sociedades desiguais. A autora defende a ideia de que a luta pela qualidade na EI, assim como em outras áreas encarregadas da infância, requer definições conceituais e metas claras, legislações, financiamento e sistemas de garantia submetidos ao monitoramento e à revisão constante dos objetivos nacionais e próprios por parte de todos os envolvidos no processo (PENN, 2011, p. 210, apud CAMPOS, 2013). Pode se afirmar, então, que tanto no Brasil como no Chile existe uma tentativa, pelo menos presente nas políticas recentes, de assumir a responsabilidade não apenas como respostas às metas compartilhadas através de leis e regulamentações, mas que deve nascer dos valores, dos diagnósticos e das expetativas que a instituição e os agentes têm de si mesmos. A partir dessa lógica, é indispensável ampliar e fortalecer a participação da comunidade educativa, fomentando o compromisso e a corresponsabilidade de todos os setores da sociedade (públicos, privados, nacionais e locais) e gerando as condições para integrar modos de responsabilização variados que permitam o planejamento, a implementação e a avaliação pertinentes, válidos e legitimados pelo contexto, de maneira a garantir os efeitos e os impactos pretendidos nelas. 


\section{CONSIDERAÇÕES FINAIS}

Os estudos realizados, primeiro em cada país e depois numa perspectiva comparada, permitiram identificar um conjunto de convergências e divergências significativas na configuração de políticas públicas de EI do Chile e do Brasil, compreender o contexto em que elas foram formuladas e destacar as principais tensões e tendências na relação Estadomunicípio na busca de novas formas de equação entre participação e responsabilização tanto nos contextos nacionais quanto nos locais, como fator de qualidade educativa. As tensões registradas nas revisões histórica e documental incidiram progressivamente tanto na descrição quanto na comparação da trajetória dos modos de gestão da Educação Infantil nos dois países, assim como na compreensão da relação - muitas vezes conflituosa - entre cada Estado e as esferas intermediárias de governo, a partir dos princípios de descentralização, qualidade e responsabilização.

Nos dois países, tem havido uma história política e social complexa, que influi na configuração de políticas públicas e reflete não só na produção de diretrizes que orientam o funcionamento do sistema e no efeito das regulações institucionais desencadeadas pelo Estado e sua administração, se não que também reflete no reajuste resultante da diversidade de ações dos diferentes agentes envolvidos - locais, nacionais e multinacionais -, das suas posições, interesses e estratégias. Assim, é possível apresentar as principais conclusões deste trabalho nos seguintes pontos:

a) A existência de uma agenda global para EI tem influenciado os ajustes da estrutura e a atuação dos países em estudo, mas esses processos não acontecem em um terreno "virgem".

Ao longo deste trabalho, foi possível evidenciar a presença constante de uma agenda global para a infância e para a Educação Infantil, estruturada por organismos internacionais que têm repercutido nas agendas nacionais do Chile e do Brasil, ao longo da história. Observou-se como as orientações externas da CDC, UNESCO, UNICEF, OCDE, Banco Mundial, entre outras, sejam elas econômicas, estruturais, sociais e/ou educativas, foram sendo apropriadas pelos Estados e incorporadas às políticas educativas num processo, conforme destacado neste estudo, que não ocorreu da mesma maneira nos dois países. Mesmo que seja possível observar diferenças nos contextos nacionais que repercutiram na definição dos papéis de cada Estado nas últimas décadas, no caso da EI é possível elucidar que a ação do poder do Estado, em ambos os países, é posicionada em função reguladora, com papel 
central na mediação exigida para a consolidação do processo de globalização. Tal como registrado nos capítulos anteriores, tanto as políticas de descentralização e municipalização da educação quanto as que promovem a EI como estratégia privilegiada para o "alívio da pobreza $^{46 "}$ foram adotadas pelos governos chileno e brasileiro como respostas associadas a uma lógica econômica transnacional e proclamada por organismos internacionais como eixo de produtividade com equidade. Da mesma maneira, quando a criança e seus direitos começaram a figurar como tema em diferentes conferências e reuniões internacionais, $o$ direito à Educação Infantil foi sendo configurado como uma questão fundamental para os países em estudo, tornando necessário, para os governos, garantir a oportunidade de acesso a esta educação e manter um padrão mínimo de qualidade de funcionamento, expansão e gestão. O interessante é que, ainda que as políticas chilenas e brasileiras se diferenciassem nos modelos de gestão, há uma inter-relação em algumas delas, tanto na apresentação de conceitos e pressupostos quanto nas concepções que os fundamentam, que são consonantes, ao mesmo tempo, às diretrizes de alcance mundial.

Três exemplos claros: a Educação Infantil em âmbito de planejamento e discurso das políticas públicas, nos dois países, ainda é apresentada e discutida como uma medida compensatória que deve privilegiar, como anunciam, as crianças e as famílias em situação vulnerável. Embora ressaltem as crianças como sujeitos de direitos, na prática da gestão, as políticas estão diretamente ligadas a condições econômicas redistributivas e de focalização, nas quais o direito é convertido em uma prestação de serviços individualizada e sujeita à variabilidade econômica que acaba resultando, no final, na segmentação e na exclusão da população que, nos discursos oficiais, deveria ser integrada, deixando a dimensão do direito comprometida e até mesmo ignorada.

Segundo, como foi destacado anteriormente, tanto nas orientações dos organismos internacionais quanto as políticas e programas em ambos os países, há uma permanência da diferenciação entre creche e pré-escola. Mesmo que atualmente a creche e a pré-escola no Chile e no Brasil sejam consideradas como uma etapa só, integradas organizacionalmente dentro de políticas de financiamento, formação docente e currículo para Educação Parvularia (no Chile) ou Educação Infantil (no Brasil), as indicações prioritariamente são pautadas a partir de formas diferenciadas: atendimento, para as crianças de até quatro anos, por meio de

\footnotetext{
${ }^{46}$ Refere-se ao perfil que a EI tomou em alguns países latino-americanos, sendo considerada como fundamental no rompimento dos ciclos de pobreza e na consolidação da equidade social. A partir dessa premissa, a Educação Infantil ganhou relevância, uma vez que poderia atuar nos setores historicamente desfavorecidos, como uma estratégia modificadora da situação de carência crítica. Veja-se no capítulo 3.1, pp.23-28.
} 
projetos integrados com outros programas sociais; e preparatório para desempenho futuro no ensino fundamental para as crianças de quatro a seis anos .

Por último, e também decorrente de indicações internacionais, a entrada do "terceiro setor" no cenário de políticas educativas reafirmou a parceria do poder público com a iniciativa privada na oferta de educação e na expansão do setor "público não estatal", compartilhando funções e legitimando a função do Estado como regulador e transferidor de recursos, dispensando as funções de intervenção e colaboração, até torná-lo finalmente, em fiscalizador externo, no caso do Brasil, e de "controlador à distância", no caso do Chile.

Conforme o exposto neste trabalho, as orientações dos organismos internacionais compõem uma agenda globalmente estruturada para infância e para a Educação Infantil vinculada a estratégias econômicas e de superação da pobreza, adaptadas por parte dos países de América do Sul na formulação de suas políticas, entre eles o Brasil e o Chile. Segundo Ball (2001, p.102), isso pode acarretar “empréstimos e cópia de fragmentos e partes de ideias de outros contextos, processo que acaba por conferir fragilidades às próprias políticas locais", resultando, por vezes, em acordos que podem ou não funcionar e configurando uma cultura de tentativas pautadas na lógica do ensaio e erro nas propostas educativas. Porém, de acordo com a linha desenvolvida nesta dissertação, não é possível caracterizar o processo como linear e isolado, nem tratar as políticas e os documentos oficiais de ambos os países como apenas reedições de propostas internacionais. Embora seja possível observar a relação entre as indicações globais e as formulações das políticas nacionais, essas não são apropriações diretas, antes são reelaboradas pelos próprios países, de forma que, se por um lado fica evidente a submissão a alguns pontos, como os citados acima, por outro também se observam algumas conquistas, vindas da influência dos movimentos da sociedade civil e acadêmica, o que demonstra que a definição de políticas de EI no Chile e no Brasil se situa contemporaneamente em uma constante arena de negociações.

\section{b) Qualidade de Educação Infantil: A busca do equilíbrio entre a avaliação externa e a construção de todos.}

Tal como foi expressado no capítulo anterior, apesar das conquistas da Educação Infantil em termos legais e do avanço no âmbito das políticas públicas e dos sistemas de gestão em ambos os países, no contexto real, muitas dessas conquistas ainda não foram consolidadas. Principalmente no que diz respeito à qualidade, há uma distância evidente entre sua definição e as ações tomadas para sua operacionalização e avaliação. De fato, a partir das 
tensões registradas ao longo deste trabalho, é possível advertir que existe um "circulo da qualidade" (PENN, 2011) presente em cada contexto estudado, dependente da história e da estrutura nacional, e carregado de consensos, arranjos e ambiguidades sobre o que "foi feito e também sobre o que se deixou de fazer" (p. 209), que reproduz e seguirá reproduzindo novas problemáticas e riscos.

Nos capítulos anteriores, foram registradas diferenças e similitudes nos processos de definição e avaliação da qualidade da EI entre o Chile e o Brasil, as quais são refletidas nas diferentes ênfases políticas e determinadas pelos modos de organização das esferas de governo e responsabilização dos agentes. As tensões destacadas revelam uma convivência pouco clara de, por um lado, políticas que concebem a qualidade no sentido de medição e/ou avaliação externa, salientando a função do poder público como regulamentador e fiscalizador; e, por outro, políticas participativas que resvalam no democratismo pois, tal como foi explicitado em ambos os contextos, nem sempre essas políticas fortalecem as capacidades locais de participação. Efetivamente, enquanto o conceito de qualidade de EI incita uma adesão maioritária e crescente por assumi-lo e compreendê-lo como forma de avaliar tanto o desenvolvimento das crianças, quanto o desempenho financeiro, administrativo e pedagógico dos responsáveis, observou-se no percurso histórico, que a qualidade tem sido orientada sob uma conceitualização que tem privilegiado o "dar conta dos resultados" como parte de ações gerenciais administradas externamente. A priorização da qualidade com racionalidade instrumental, sujeita apenas ao logro de metas e consecução de procedimentos exigidos, favorece em grande medida às estruturas governamentais centrais mais do que às autonomias locais, o que pode acabar ameaçando e "não garantindo", em algumas circunstâncias, a pertinência dos processos pedagógicos e a inclusão socioeducativa da gestão local. Não obstante, ao mesmo tempo em que essa tendência toma força nos dois países, a importância de políticas de qualidade democráticas e participativas também começa a ocupar espaços em vários lugares e movimentos - tanto da sociedade civil, quanto acadêmicos - que defendem a qualidade a partir de adequadas leituras e análises macro e micro, assim como desde uma perspectiva baseada no reconhecimento da Educação Infantil como tarefa compartilhada e desenvolvida em um cenário que implica interações entre diferentes atores, contextos e organizações.

A pesquisa realizada aponta para o caráter "negociável" que a qualidade da EI está adquirindo em ambos os países, termo "qualidade negociada" que no Brasil se encontra vigente por mais tempo do que no Chile, e que tende a ser vista não mais como um valor absoluto adequado a um padrão estabelecido a priori - como aconteceu no Chile por muito 
tempo -, nem como dado resultante de gestões altamente variáveis entre si - como no caso do Brasil -, senão como um processo, de acordo com Bondioli (2004, p.14), de construção participativa, autorreflexivo, contextualizado e transformador. Essa definição contrasta com a noção corrente de qualidade adotada pelas políticas públicas neoliberais presentes nos dois países, cuja concepção é quase sempre eivada de uma pseudoparticipação que objetiva legitimar a imposição verticalizada de "padrões de qualidade" externos ao local avaliado. Destaca-se, conforme o exposto pela autora, dois aspectos essenciais na construção de qualidade: os indicadores e o projeto educativo, os quais enfatizam as capacidades de significação, produção e colaboração dos agentes educativos envolvidos. Para ela, os indicadores são importantes para avaliar o funcionamento dos sistemas educativos locais e trazem para a Educação Infantil um método comparativo de contextos que permite saber qual é o grau de desempenho e uso de recursos da instituição ou esfera de governo, assim como as deficiências que são necessárias combater, sobretudo quando se envolvem recursos públicos. Porém, os indicadores adquirem valor pela significação compartilhada que possuem perante os agentes da instituição, mais do que pelo valor numérico ou de análise que possam gerar (Bondioli, 2004, p. 21). O projeto pedagógico, por sua vez, "assume um significado negociável, porque constitui uma espécie de 'pacto' entre o órgão público e o órgão gestor da rede (...), que define compromissos e responsabilidades recíprocas (...)” (IBIDEM, p. 22). Desta maneira, extrai-se do anterior a importância da construção que se desenvolve no interior da instituição educativa e que deve ter um lugar fundamental no curso da avaliação institucional, a qual deve ser acompanhada pelas políticas públicas e as esferas intermediárias de governo a partir da inter-relação dos múltiplos agentes: da instituição para com as crianças; da instituição consigo mesma; da instituição com os gestores do sistema escolar; e dos gestores do sistema para com a instituição.

Este trabalho salienta, portanto, a noção de "qualidade negociada" da EI, sem que isso sugira, sequer, que cada instituição defina isoladamente seus indicadores e seu projeto educativo de qualidade, muito menos que a normatização da Educação Infantil de qualidade "para todos" acabe por uniformizar padrões nacionais em detrimento das caraterísticas locais. Quaisquer dessas situações, em separado, podem conduzir à perpetuação de desigualdades e decorrer em consequências únicas em cada país, tal como as registradas ao longo desta pesquisa. $\mathrm{O}$ que se propõe é uma interface decisiva entre a comunidade educativa e as políticas centrais, na direção da construção do envolvimento amplo e responsável com os atores da instituição em um processo de avaliação institucional que veja no próprio projeto pedagógico uma forma de estabelecer um pacto pela melhoria da qualidade, uma qualidade 
negociada, sim, mas com a exigência de uma contrapartida de responsabilidades assumidas pelo poder público através de um monitoramento de qualidade construída coletivamente e onde as esferas intermediárias assumem um papel decisivo.

Em outras palavras, e de acordo com Penn (2011), assume-se que a qualidade da EI não pode se distanciar do contexto, mas se valoriza a pertinência do papel do Estado e do município na regulamentação e na participação conjunta da construção dessa qualidade. $\mathrm{O}$ aumento do interesse político do Estado por regulamentar a Educação Infantil conduzindo a expansão do atendimento e a aferição de políticas curriculares, de formação de professores, financiamento e cobertura, pode até considerar a avaliação externa como forma democrática da macropolítica para garantir os direitos educacionais universais de todas as crianças, mas isso não pode abrir mão da tomada de decisões importantes das outras esferas de ação, dentro de "espaços democráticos" e condições para práticas democráticas ativas. É importante considerar que a qualidade negociada implica uma relativização, sem que, por isso, deixe-a isenta de juízo de valor. A qualidade continuamente estará ligada a um tipo de avaliação feita para determinar se uma ou outra prática, processo ou resultado é de qualidade ou não, podendo haver mais de uma resposta correta para qualquer questão. Se atualmente ambos os países - Brasil desde muito antes que o Chile, por certo - assumem o discurso da importância da contextualização de qualidade na EI, do mesmo modo devem assumir e legitimar a convivência de distintas formas e espaços de trabalho para construí-la e por tanto, para avaliála. Deste modo, é necessário que continue ganhando força a ideia de favorecer a conciliação em ambos os países, daquelas políticas públicas que garantam o equilíbrio entre a organização do sistema e a construção dos espaços de qualidade para a educação de infância.

\section{c) $O$ município pode se configurar como mobilizador das negociações de qualidade da EI.}

Neste estudo, foram registradas acentuadas tensões e disparidades entre as proposições e as implementações de políticas públicas de EI em ambos os países. Os fatores são os mais diversos: as políticas públicas centrais v/s a realidade municipal, a gestão administrativa, financeira e pedagógica dos municípios num sistema descentralizado, a definição e a operacionalização da qualidade da EI, a responsabilização e a valorização dos profissionais e gestores, dentre outros. Diante da complexidade da continuação das lutas internas pela busca do equilíbrio entre as forças de integração e diferenciação, entre unidade e descentralização, entre padronização e diversidade, relações dialéticas altamente 
questionáveis, a gestão das esferas intermediárias de governo pode se configurar como um importante eixo de qualidade da EI.

No intuito de tornar a participação do contexto e a gestão democrática como pilares da EI de qualidade, tendência percebida tanto no Chile como no Brasil, destaca-se a ideia de que a mudança deve partir como uma construção local apoiada pelo Estado, mas não como uma transferência desde um órgão central para a "ponta" do sistema, e sim como uma nova forma de relacionamento que exclua tanto os modelos autoritários de gestão baseados na hierarquização das decisões quanto o populismo e o democratismo de gestões que transferem inadequadamente (para não dizer que abandonam) as decisões para o final da corrente de gestão, tornando-as unilaterais da mesma maneira.

Especificamente em Educação Infantil, faz-se necessário considerar que, tal como foi evidenciado neste trabalho, os sentidos de responsabilização do Estado e dos municípios decorrentes dos crescentes processos de descentralização supõem a mobilização dos agentes envolvidos e as transformações das subjetividades e práticas pedagógicas em torno de objetivos nem sempre próprios. Isso significa que tanto os níveis intermediários como locais, assim como as instituições e as famílias das crianças experimentam distintos graus de influência na tomada de decisões educativas, mas tais decisões respondem a exigências muito mais amplas, que nem sempre se relacionam necessariamente com as demandas locais. De fato, as políticas destinadas a garantir a qualidade da E.I incentivam níveis de autonomia e participação, mas simultaneamente maiores níveis de estruturação e controle do governo sobre a gestão municipal e institucional. Assim, no duplo movimento entre noções de qualidade baseadas no gerenciamento e noções de democratização, a articulação entre a ação do Estado e o contexto local é fundamental.

Não há dúvida de que, para conseguir tal articulação, é preciso o fornecimento dos recursos financeiros a serem administrados, mas também as ferramentas para fortalecer os processos coletivos baseados nos pilares de descentralização, qualidade e responsabilização. O investimento dos governos no desenvolvimento de políticas públicas que envolvam a multidimensionalidade da questão da participação do contexto deve promover efetivamente instâncias de apoio à autonomia administrativa e política dos municípios, e, com isso, saber/fazer a educação politicamente, formar a comunidade para a participação efetiva nos processos decisórios da instituição, criar/implementar políticas que atendam, de fato, os interesses educacionais e sociais locais, promover o acompanhamento, avaliar e redimensionar as ações procurando aproximar as macropolíticas educacionais das micropolíticas, visando ao alcance de uma prática educativa verdadeiramente democrática. 
Esse desafio não basta apenas com aceitar que existem diferentes níveis de participação, nem propiciar espaços para que a comunidade educativa "faça parte", o desafio é possibilitar espaços em que os sujeitos além de "fazerem parte" também "tomem parte" e tenham real poder de decisão. Acredita-se que isto não poderá ser concretizado em cada localidade e instituição se não houver um processo interno de reflexão conduzido pela comunidade educativa de forma participativa. É nessa tarefa que o município pode se perfilar com um importante papel de mobilizador e de canalizador a cumprir.

Mobilizador porque não apenas os gestores e gestoras devem participar. É a comunidade educativa completa, e isso inclui gestores municipais, professores, funcionários, famílias e crianças num processo de construção, definição e avaliação democrática da EI que não é simples, pois construir uma nova lógica de sociedade participativa é andar na contramão das experiências históricas e políticas gestadas até então. Portanto, acredita-se que as redes municipais (no Brasil) ou departamentos municipais de educação (no Chile) devem promover um processo alimentado pelo diagnóstico da realidade do contexto, a formação da comunidade para a participação e o conhecimento da legislação e das políticas públicas nacionais para, desta forma, canalizar as demandas locais em prol do rompimento de desigualdades e da conquista de condições de funcionamento e trabalho dos agentes educativos, deixando margem para a autonomia da instituição no encontro de um caminho próprio de praticas educativas que incentivem a melhoria da qualidade da EI. Nesse sentido, os Conselhos Escolares de EI, estabelecidos no Brasil há mais de uma década e no Chile agora em fase de conhecimento, podem se consolidar como espaço mobilizador e canalizador da gestão democrática e da participação da sociedade na definição dos rumos da EI pública. A sua efetivação, não somente técnica, mas também política no exercício da participação, implica a presença de gestores (in)formados e comprometidos para assim constituir a possibilidade de um novo senso comum de democracia, calcado na crença da contextualização da EI como eixo de qualidade, que respeite a autonomia do contexto, a responsabilização dos agentes educativos e os direitos da criança.

Através dos fundamentos metodológicos da Educação Comparada que sustentam este estudo, foram indicados os principais movimentos dos estados chileno e brasileiro na configuração de políticas públicas de EI e suas repercussões para os sistemas nacionais. A partir das linhas de teorização sobre descentralização, qualidade e responsabilização, foi possível extrair as implicações e as possibilidades da gestão local em cada país, resgatando as suas potencialidades e suas implicações em função da busca de EI de qualidade, um equilíbrio que, por sua vez, transforme o mesmo sistema. 
Em 2016, o governo chileno finalizou o estabelecimento das Intendências Regionais de Educação Infantil presentes em cada região do país, assim como o funcionamento dos Serviços Locais de Educação que se perfilam com atribuições muito semelhantes aos Conselhos Escolares. A secretaria ministerial de EI enfatiza, em cada um dos seus discursos, a colaboração entre os municípios e o MINEDUC, pois, "para fortalecer as alianças é muito importante que os municípios estejam bem informados dos sentidos da Reforma de Educação Infantil (...) sobretudo nas linhas de difusão de iniciativas, fortalecimento da capacidade de gestão municipal e a geração de estudos e matérias vinculadas ao setor ${ }^{47 \%}$. Paradoxalmente, nesse mesmo ano, o Senado recusou a integração das creches VTF aos Serviços Locais de Educação, e ainda não foram registrados avanços oficiais para definir qualidade de EI sob pressupostos participativos, nem para o estabelecimento de espaços de participação democrática das gestões municipais.

O Brasil, por sua parte, vive um período de avanços, mas também de muita turbulência política. Foi apresentada a segunda versão da Base Nacional Comum Curricular que, incluindo Educação Infantil, espera ser aprovada no final de 2017. Por outro lado, as recentes decisões governamentais, como: a obrigatoriedade da matrícula no ensino fundamental de crianças de 6 anos; a exclusão de questões de diversidade de gênero e sexual dos planos municipais e estaduais de educação; e a aprovação da PEC n ${ }^{\circ} 55 / 16$, que congela por vinte anos os investimentos nas áreas sociais, em especial, as de saúde e educação, obstaculizam o incremento do investimento em EI, o fortalecimento do regime de colaboração e o suporte às autonomias locais.

É clara a continuação de lutas e contradições em ambos os países, porém, sem querer tirar lições nem fórmulas mágicas para uma EI de qualidade, a aproximação e a compreensão de outro contexto contribuiu significativamente ao entendimento da realidade chilena frente aos novos desafios. Assim, embora assuma-se que as políticas públicas têm sido configuradas num cenário de contradições, estas mesmas permitem priorizar quatro considerações para a EI chilena atual:

a) A importancia da consolidação de uma definição de qualidade oficial a partir de um processo nacional participativo, em que os diferentes agentes envolvidos com a EI possam concertar e construir a concepção de qualidade da EI do país, coerente com os pressupostos participativos governamentalmente preconizados.

47 Disponível em http://parvularia.mineduc.cl/2017/01/11/subsecretaria-diaz-reafirma-convenio-colaboracionmunicipalidades-mineduc/. Data de acessso 04/03/2017 
b) Considerar nas políticas de asseguramento da qualidade formas de avaliação da EI que incluíam processos amplos de participação e melhoria institucional. Definição de critérios básicos de gestão e parâmetros de qualidade de caráter nacional, mas que permitam uma implementação democrática, em função do respeito aos sentidos de cada projeto pedagógico e que proveja os recursos necessários para dar sustentabilidade ao processo e, ao mesmo tempo, dar a flexibilidade para a tomada de decisões contextualizadas e que respondam à realidade local.

c) Assumir a complexidade e a integralidade da construção da qualidade da EI como um processo transparente. Dar conta de que a qualidade educativa vai muito além de mensurar e padronizar indicadores, de que se trata de pôr a avaliação em prol da melhoria da EI e não como juízo ou sanção dos problemas e fracassos. Requer-se um processo e instrumentos multidimensionais de fácil aplicação pelos membros da comunidade educativa, professionais, administrativos, famílias e crianças, que não se limitem à constância de presença ou ausência de indicadores nacionais, senão que permitam a valoração desses, concebendo a avaliação como uma instância que recolha e observe a interseção da percepção dos participantes, os objetivos de cada projeto educativo e os indicadores nacionais dentro de um mesmo processo de melhoria institucional.

d) O município deve se constituir como mobilizador e canalizador do processo, tendo como foco o acompanhamento e a retroalimentação, tanto externos, quanto internos. É fundamental a formação dos gestores locais para que a operacionalização da qualidade não se transforme num exercício de poder hierarquizado pelo qual o avaliador externo tem "a verdade e a solução aos problemas”. A participação dos agentes locais não estará assegurada enquanto não existir respeito das diversidades contextuais, da preparação, da representação na tomada de decisões e do compromisso. Sem esses elementos, qualquer reforma legislativa pode perder o sentido pois, para mudar a realidade, todo intuito de mudança deve se articular como instrumento de luta coletiva.

Finalmente, trata-se de abordar o tema da qualidade da EI como um processo social complexo, multifatorial e de construção permanente, que deve centrar-se na busca de coerência nos sentidos compartilhados e nas análises críticas que permitam emancipar a EI do olhar simples e ingênuo, para avançar para uma efetiva transformação na educação das crianças e onde os primeiros agentes da busca dessa qualidade sejam as próprias comunidades educativas. 
Entretanto, no momento em que a sociedade se volta sobre si mesma e se inscreve na difícil busca de sua autenticidade, começa a dar evidentes sinais de preocupação pelo seu projeto histórico. Quanto mais cresce esta preocupação, mais desfavorável se torna o clima para o compromisso.

Estamos convencidos de que o momento histórico da América Latina exige de seus profissionais uma séria reflexão sobre sua realidade, que se transforma rapidamente, e da qual resulte sua inserção nela, inserção esta que, sendo crítica, é compromisso verdadeiro. Compromisso com os destinos do país. Compromisso com seu povo. Com o homem concreto.

Compromisso com o ser mais deste homem. Se, numa sociedade preponderantemente alienada, o profissional, pela natureza mesma da sociedade hierarquicamente estruturada, é um privilegiado, numa sociedade que se está abrindo o profissional é um comprometido ou deve sê-lo.

Fugir da concretização deste compromisso é não só negar-se a si mesmo como negar o projeto nacional.

Paulo Freire (Educação e Mudança) 


\section{REFERÊNCIAS BIBLIOGRÁFICAS}

ABRUCIO, F. Reforma política e federalismo. Desafios para a democratização brasileira. In: VANNUCHI, P.; BENEVIDES, M.V.; KERCHE, F. (orgs). Reforma Política e Cidadania. São Paulo: Fundação Perseu Abramo, 2003. p. 225-265.

ADLERSTEIN, C. La política pública de la educación parvularia chilena: Una mirada desde la historia y su actualidad. Revista Docencia, Santiago de Chile, n.48, 2012.

ADRIÃO, T., GIL, J. (orgs.) Educação no Chile: Olhares do Brasil. São Paulo. Ed. Xamã. 2009.

ANDRADE, LBP. Educação infantil: discurso, legislação e práticas institucionais [online]. São Paulo: Editora UNESP; São Paulo: Cultura Acadêmica, 2010. 193 p. ISBN 978-85-7983085-3. Available from SciELO Books <http://books.scielo.org>.

ARELARO, L.R.G. Financiamento e qualidade da educação brasileira. Algumas reflexões sobre o documento "Balanço do primeiro ano do FUNDEF - Relatório MEC." Em: DOURADO, L. F. Financiamento da educação básica. São Paulo: Autores Associados, 1999.

A não transparência nas relações público-privadas: o caso das creches conveniadas. Em: ADRIAO, T.; PERONI, V. (Org.). Público e privado na educação: novos elementos para o debate. São Paulo: Xamã, 2008. p. 51-66

O ensino fundamental de nove anos e o direito à educação. Educação e Pesquisa, São Paulo, v.37, n.1, 220p. 35-51, jan./abr. 2011.

ARRETCHE, M. Relações Federativas nas Políticas Sociais. Educação e Sociedade, Campinas, UNICAMP-CEDES, v. 23, n. 80, p. 25-48, set. 2002.

AZEVEDO, J. A educação como política pública. Campinas: Editora Autores Associados, 2001.

BALL, S. Cidadania Global, Consumo e Política Educacional. Em: SILVA, L. (Org.) A Escola Cidadã no Contexto da Globalização. 2 ed. Petrópolis: Vozes, 1998.

BARBOSA, M. (Coord). Mapeamento e análise das propostas pedagógicas municipais para a educação infantil no Brasil. Relatório de pesquisa. MEC, UFRGS, Brasília, 2009.

BARRETO, A. A educação infantil no contexto das políticas públicas. Revista Brasileira de Educação. Rio de Janeiro, n. 24, p. 53-65, set./out./nov./dez, 2003.

BARRETO, M.; VIGEVANI, T. Cenário global e o espaço de intervenção dos governos locais. Em: MARTINS, A.; OLIVEIRA, C.; BUENO, M. Descentralização do Estado e municipalização do ensino: problemas e perspectivas. Rio de Janeiro: Ed. DP\&A, 2004. 
BARROSO, J. O reforço da autonomia das escolas e a flexibilização da gestão escolar em Portugal. Em: FERREIRA, N. (Org.). Gestão Democrática da Educação: atuais tendências, novos desafios. São Paulo: Ed. Cortez, 2008.

. O Estado, a Educação e a Regulação das Políticas Públicas. Educação \& Sociedade, Campinas, v. 26, n. 92, p. 725-751. 2005a. Disponível em:

< http://www.scielo.br/pdf/es/v26n92/v26n92a02.pdf>. Acesso em: 27/09/2016.

BOBBIO, N.; MATTEUCCI, N.; PASQUINO, G. Dicionário de Política. Tradução: Carmen C. Varriale, Brasília: UnB, 2009. v. 1 e 2.

BONDIOLI, A. O projeto pedagógico da creche e a sua avaliação: a qualidade negociada. Campinas: Autores Associados, 2004.

BONDIOLI, A.; SAVIO, D. (Org). Participação e Qualidade em Educação da Infância: Percursos de compartilhamento reflexivo em contextos educativos. Ed. UFPR. 2013.

BORON, A. Os "novos leviatãs" e a pólis democrática: neoliberalismo, decomposição estatal e decadência da democracia na América Latina. Em: SADER, E.; GENTILI, P. (orgs). Pós-Neoliberalismo II: Que Estado para que democracia? Rio de Janeiro: Editora Vozes/CLACSO, 1999. p. 7-67.

A sociedade civil depois do dilúvio neoliberal. Em: SADER, E.; GENTILI, P. (Orgs.). Pós-neoliberalismo: as políticas sociais e o Estado democrático. 7. ed. Rio de Janeiro: Paz e Terra, 2007.

BRASIL. Ministério da Educação. Secretaria de Educação Básica. A educação infantil nos países do MERCOSUL: análise comparativa da legislação / Ministério da Educação. Secretaria de Educação Básica. Brasília: MEC/SEB, 2013. 132 p.

. Constituição da República Federativa do Brasil: promulgada em 5 de outubro de 1988. Brasília, DF: Senado Federal/ Centro Gráfico, 1988.

Ministério da Educação e Cultura. Secretaria Geral. Comissão de Coordenação Geral. Programa Nacional de Educação Pré-Escolar. Brasília/DF, 1981

Lei ${ }^{\circ}$ 8069/90 de 13 de julho de 1990. Dispõe sobre o Estatuto da Criança e do Adolescente e dá outras providências. Presidência da República. Casa civil. 1990.

Lei no 9394 de 20 de dezembro de 1996. Estabelece a Lei de Diretrizes e Bases da Educação Nacional. 1996. Diário Oficial da União. Brasília, DF, 1996.

Lei n. 9.424, de 24 de dezembro de 1996. Dispõe sobre o Fundo de Manutenção e Desenvolvimento do Ensino Fundamental e de Valorização do Magistério - Fundef. Diário Oficial da União, Brasília, DF, 26 dez. 1996.

Ministério da Educação e do Desporto. Referencial Nacional Curricular Nacional para a Educação Infantil. Brasília: MEC/SEF, 1998. 
- Ministério da Educação e do Desporto. Subsídios para credenciamento e funcionamento das instituições de Educação Infantil. Brasília, 1998.

. Resolução ${ }^{\circ}$ 01, de 07/04/1999. Define as Diretrizes Curriculares Nacionais para a Educação Infantil. Brasília: CNE/CEB, 1999.

Lei complementar $n^{\circ} 101$, de 4 de maio de 2000. Estabelece normas de finanças públicas voltadas para a responsabilidade na gestão fiscal e dá outras providências. Diário Oficial da União. Brasília, DF, 2000.

. Lei $\mathrm{n}^{\circ} 10.172$, de 9 de janeiro de 2001. Aprova o Plano Nacional de Educação e dá outras providências. Diário Oficial da União. Brasília, DF, 2001.

Política nacional de Educação Infantil: pelo direito das crianças de zero a seis anos à educação. Brasília: Secretaria de Educação Básica. Ministério da Educação, 2005a.

. Proinfantil, 2005b. Disponível em: http://portal.mec.gov.br. Dados capturados em dezembro de 2010.

. Parâmetros Nacionais de Qualidade para a Educação Infantil. Brasília: Ministério da Educação. Secretaria de Educação Básica, 2006

Lei $\mathrm{n}^{\circ}$ 11.494, de 20 de junho de 2007. Regulamenta o Fundo de Manutenção e Desenvolvimento da Educação Básica e de Valorização dos Profissionais da Educação FUNDEB, de que trata o art. 60 do Ato das Disposições Constitucionais Transitórias; altera a Lei no 10.195, de 14 de fevereiro de 2001; revoga dispositivos das Leis nos 9.424, de 24 de dezembro de 1996, 10.880, de 9 de junho de 2004, e 10.845, de 5 de março de 2004; e dá outras providências. Brasília, DF, 21 jun. de 2007a.

Ministério da Educação. Secretaria de Educação Básica. Política de Educação Infantil no Brasil: Relatório de Avaliação. Brasilia/DF, 2009

Orientações sobre convênios entre secretarias municipais de educação e instituições comunitárias, confessionais ou filantrópicas sem fins lucrativos para a oferta de educação infantil. Brasília: MEC, SEB, 2009a.

- Resolução $n^{\circ}$ 5, de 17 de dezembro de 2009. Fixa as Diretrizes Curriculares Nacionais para a Educação Infantil. Brasília: CNE/CEB, $2009 \mathrm{~b}$.

Emenda Constitucional n. 59, de 11 de novembro de 2009. Acrescenta $\S 3^{\circ}$ ao art. 212 da Constituição Federal, dá nova redação aos incisos I e VII do art. 208, de forma a prever a obrigatoriedade do ensino de quatro a dezessete anos e ampliar a abrangência dos programas suplementares para todas as etapas da educação básica, e dá nova redação ao $\S 4^{\circ}$ do art. 211 e ao $\S 3^{\circ}$ do art. 212 e ao caput do art. 214 , com a inserção neste dispositivo de inciso VI. Diário Oficial da União. Brasília, DF, 2009c.

. PROJETO DE LEI 8.035. Aprova o Plano Nacional de Educação para o decênio 2011-2020 e dá outras providências. Brasília, 2010b. 
CAMPOS, M. M.; FULLGRAF, J.; WIGGERS, V. A qualidade da educação infantil brasileira: alguns resultados de pesquisa. Cadernos de Pesquisa. São Paulo, n.127, 2006.

CAMPOS, M. M.; ROSEMBERG, F.; FERREIRA, I. M. Creches e pré-escolas no Brasil. São Paulo: Cortez, 1995.

CAMPOS, M. M. et al. Qualidade da educação infantil: um estudo em seis capitais Brasileiras. Cadernos de Pesquisa v.41, n.142, 2011. p.20-54.

. Entre as políticas de qualidade e a qualidade das práticas. Cadernos de Pesquisa v.43, n.148, (2013) pp.22-43.

A legislação e as políticas nacionais de educação infantil e a realidade: desencontros e desafios. Em: MACHADO, M ${ }^{a}$. L. de A. Encontros e desencontros em educação infantil. São Paulo: Cortez, 2002.

Educação e políticas de combate à pobreza. Revista Brasileira de Educação, n.24, Set /Out /Nov /Dez 2003. p.183-191.

CAMPOS, R. Educação Infantil e Organismos Internacionais: uma análise dos projetos em curso na América Latina e suas repercussões no contexto nacional. $215 \mathrm{f}$. Tese (Doutorado em Educação) - Centro de Ciências da Educação - PPGE, Universidade Federal de Santa Catarina, Florianópolis, 2008.

CANDIA, A. Razones y Estrategías de la Descentralización Educativa: Un Análisis Comparado de Argentina y Chile. Revista Iberoamericana de Educação, 2004. n 34.

CASSASSUS, J. El precio de la evaluación estandarizada: la pérdida de calidad y la segmentación social. Revista Brasileira de Política e Administração da Educação. RBPAE2007. v.23, n.1, p. 71-79

CASTRO-PAREDES, M. Códigos para el análisis de política educativa local en Chile: temas pendientes. Ensaio de Avaliação de Políticas Públicas Educacionais, Rio de Janeiro, 2010. v.18. n. 67.

CLARKE, J. Thriving on Chaos? Managerialisation and Social Welfare. Em: CARTER, J. Postmodernity and the fragmentation of welfare. London, Ed. Routledge.1998. p.171-186.

CORNEJO, R. El experimento educativo chileno 20 años después: una mirada crítica a los logros y falencias del sistema escolar. REICE - Revista Electrónica Iberoamericana sobre Calidad, Eficacia y Cambio en Educación, 2006. v. 4, n.1.

CORREA, B. Políticas de educação infantil no Brasil: Ensaio sobre os desafios para a concretização de um direito. Jornal de políticas educacionais, n. 9, jan./jun., 2011, p.20-29.

CORVALAN, J.; MCMEEKIN, R. Accountability educacional: posibilidades y desafíos para America Latina a partir de la experiencia internacional. Santiago, Chile. Ed. San Marino. 2006. p.125-135. 
COX, C. La Reforma de la educación chilena: contexto, contenidos, implementación. Colección de Estudos CIEPLAN, 1997. n.45, pp 5-32.

CHAMBOREDON, J.; PRÉVOT, J. O "ofício de criança": definição social da primeira infância e funções diferenciadas da escola materna. Trad. Ferreira, M. Cadernos de Pesquisa. n 59, São Paulo, nov., 1986.

DALHBERG, G.; MOSS, P.; PENCE, A. Beyond Quality in Early Childhood Education and Care: Postmodern Perspectives. USA. Ed. Falmer Press, Taylor \& Francis Inc. 1999.

.; __ . B B B B Languages of Evaluation. New Zealand Journal of Teachers' Work, v. 5, Issue 1, 2008. p. 312.

DALE, R. A promoção do mercado educacional e a polarização da educação. Educação, Sociedade e Cultura. n $^{\circ}$ 02. Porto: Edições Afrontamento, 1994.

DEMO, P. Política Social, educação e cidadania. Campinas, São Paulo: Papirus, 1994.

DIDONET, V. Balanço crítico da educação pré-escolar nos anos 80 e perspectivas para a década de 90. Aberto, Brasília, ano 10, n.50/51, abr./set., 1992.

ESPINOLA, V. La Descentralización Educativa en Chile: Continuidad y Cambio de un Proceso de Modernización. Revista Latinoamericana de Innovaciones Educativas, 1997. Año VI, n. 16.

FALABELlA A.; OPAZO, C. Sistema de Aseguramiento de la Calidad y procesos de mejora: Una mirada desde la gestión educativa. Estudio encargado por el Ministerio de Educación y UNESCO. Chile. 2014

FARIA, A. L. G. Políticas de regulação, pesquisa e pedagogia na educação infantil, primeira etapa da educação básica. Revista Educação \& Sociedade. Campinas. Vol. 26, n.92, p. 1013 1038, out., 2005.

FERREIRA, A. O sentido da Educação Comparada: uma compreensão sobre a construção de uma identidade. Revista Educação. Porto Alegre, v. 31, n. 2, p. 124-138, maio/ago. 2008.

FILMUS, D. La descentralización educativa: elementos para el análisis de un proceso abierto. Coloquio Regional sobre Descentralización de la Educación en América Central, Cuba y República Dominicana, nov. 3-5, San José, Costa Rica, CLAD. 1997.

FIORI, J. L. O Federalismo diante do desafio da globalização. Em: AFFONSO, R.; SILVA, P. (orgs.). A Federação em perspectiva: ensaios selecionados. São Paulo: FUNDAP, 1995a. p.19-38.

FUNDAÇÃO CARLOS CHAGAS. Educação Infantil no Brasil: Avaliação Quantitativa e Qualitativa, Relatório Final. 2010. 
GAITÁn MUÑOZ, L. El Bienestar social de la Infancia y los Derechos de los Niños. Política y Sociedad. v. 43, $\mathrm{n}^{\circ}$ 01, Facultad de Ciencias Políticas y Sociología. Campus de Somosaguas. Madrid, 2006.

GASPAR, M. Os impactos do FUNDEB na Educação Infantil brasileira: oferta, qualidade e financiamento. Revista Evidencia, Araxá, 2010, n.6, p.121-136.

GENTILI, P. A. A.; SILVA, T. T. (org.) Neoliberalismo, qualidade total e educação: visões críticas. Petrópolis: Vozes, 1996. p. 93-110.

GENTILI, P. (Coord.). A falsificação do consenso: simulacro e imposição na reforma educacional do neoliberalismo. 3 ed. Petrópolis, RJ: Vozes, 2002.

GIL, J. O mito da descentralização do ensino: o caso chileno. São Paulo: USP, 2000. 192 f. Dissertação (Mestrado em Educação) - Faculdade de Educação, Universidade de São Paulo, São Paulo, 2000.

Glewwe, P. e Kassouf A (2008). The Impact of the Bolsa Escola/Familia Conditional Cash Transfer Program on Enrollment, Drop Out Rates and Grade Promotion in Brazil. Department of Applied Economics, University of Minnesota. Disponível em http://www.ipcundp.org/pub/port/IPCOnePager107.pdf. Data de acesso 17/12/2016

GOMEZ, C. A educação infantil no fogo cruzado das relações inter e intragovernamentais. Em: MINISTÉRIO DE EDUCAÇÃO, Política de Educação Infantil no Brasil: Relatório de Avaliação. Ed. MEC, 2009. p. 99-120.

GOBIERNO DE CHILE. Constitución política de la República. Santiago de Chile. 1980. 111 p.

Agencia de Calidad de la Educación. Estudio de Calidad Educativa en Educación Parvularia: Experiencias Internacionales y Representaciones Sociales Nacionales.Universidad Alberto Hurtado, Santiago de Chile, 2015.

. Consejo Asesor Presidencial para la Reforma de las Políticas de Infancia. El futuro de lós niños es siempre hoy. Santiago de Chile, junio de 2006.

. Ley n. ${ }^{\circ}$ 18.962, Orgánica Constitucional de Enseñanza (LOCE). Diario Oficial de la República de Chile, Santiago, Chile, 7 marzo de 1990.

. Ley n. 20.370 , General de Educación (LGE). Diario Oficial de la República de Chile, Santiago, Chile, 12 de setembro de 2009.

Ley $\mathrm{n}^{\circ}$ 20.529, del Sistema Nacional de Aseguramiento de la Calidad de la Educación Parvularia, Básica y Media, Diario Oficial de la República de Chile, Santiago, Chile, 11 de Agosto de 2011.

Ley $\mathrm{n}^{\circ}$ 20.845, Ley de Inclusión Escolar, Diario Oficial de la República de Chile, Santiago, Chile, 8 de junio de 2015. 
- Ministerio del Interior. Chile Crece Contigo. Cuatro Años Creciendo Juntos.

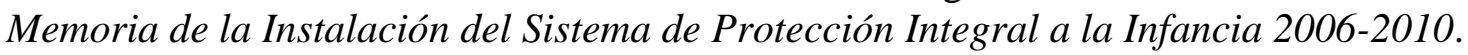

2005.

. Ministerio de Educación. Bases Curriculares de La Educación Parvularia. Chile.

GOERGEN, P. L. Educação comparada: uma disciplina atual ou obsoleta? Pro-posições. Campinas, UNICAMP-FE, n. 6, p. 5-20, dez. 1991.

HADDAD, L.; OLIVEIRA, E. C. de. Secretaria do Bem-Estar Social e a creche: dos primórdios a 1970. Serviço Social \& Sociedade. São Paulo, v.11, n.34, p.90-117, dez.1990.

A trajetória da educação infantil em quatro ciclos. Em: XAVIER, M. E. S. P. (org.). Questões de educação escolar. Campinas: Alínea, 2007.

A creche em busca de identidade. São Paulo. Loyola, 1991.

HERMOSILlA, B. La Educacación Parvularia en la Reforma: Una Contribución a la Equidad. Ministerio de Educación de Chile. 1998.

KALOYIANNAKI, P.; KAZAMIAS, A. Os primórdios modernistas da educação comparada: o tema protocientífico e administrativo reformista-meliorista. Em: Cowen R., Kazamias, A. e Ulterhalter, E. Educação Comparada: Panorama Nacional e Perspectivas. Brasília: UNESCO, CAPES, 2012. 2v, p.25-54

KISHIMOTO, T. M. A pré-escola em São Paulo (1877 a 1940). São Paulo: Loyola, 1988.

KRAMER S.; TOLEDO L.; BARROS C. Gestão da educação infantil nas políticas municipais. Pontifícia Universidade Católica do Rio de Janeiro, Rio de Janeiro, RJ, Brasil. Revista Brasileira de Educação. v. 19 n. 56 jan.-mar. 2014

As crianças de 0 a 6 anos nas políticas educacionais no Brasil: educação infantil e/é fundamental. Revista Educação \& Sociedade. Campinas, vol. 27, n. 96 - Especial, p. 797-818, out. 2006. 1995.

A Política do Pré-Escolar no Brasil: A arte do Disfarce. 5. ed. São Paulo: Cortez,

MACHADO, C. Políticas públicas para a educação da criança pequena: uma análise das décadas de 1970 a 1990. Jornal de Políticas Educacionais. $N^{\circ} 13$ | janeiro-junho de 2013 | PP. 37-46.

MAIA, M.; CRUZ, S.; VIEIRA, S. Eleição de Diretores no Ceará - uma visão geral do processo. Em: VIEIRA, S. Eleição de Diretores: o que mudou na escola? Brasília: Plano, 2011. 
MARTINS, G. Educação Infantil: políticas públicas e ação institucional. 161 f. Dissertação (Mestrado em Educação) - Centro de Ciências Humanas e Sociais, Universidade Federal de Mato Grosso do Sul, Campo Grande. 2000.

MENESES, C. Educação Infantil: a interseção entre as políticas públicas, a gestão educacional e a prática pedagógica, um estudo de caso no município de Itabuna - Bahia. Tese 274 f. (Doutorado em Educação) - Faculdade de Educação, FACED, Universidade Federal de Bahia, Salvador, 2012.

MIDAGLIA, C.; ROBERT, P. Uruguay: un caso de estrategias mixtas de protección, salud y alimentación. In ZICCARDI, A. (Org.) Pobreza, desigualdad social y ciudadanía: los límites de las políticas sociales en América Latina. Buenos Aires: CLACSO, mar. 2001.

MONCKEBERG, A. Prevención de la desnutrición en Chile. Revista Chilena de Nutrición, Santiago, 2003. v. 30, n. 1, p. 160-176.

MONJE, J. et al. La Acción Educativa en Educación Parvularia: Una Mirada Etnográfica. 239 f. Trabalho de conclusão de curso. (Pedagogia em Educação Inicial) - Facultad de Ciencias Sociales, Universidade de Chile, Santiago, 2007.

OLIVA, M. Política educativa y profundización de la desigualdad en Chile, Instituto de Investigación y Desarrollo Educacional. Revista Estudios Pedagógicos XXXIV. Talca, Chile, $\mathrm{n}$ 2: 207-226, 2008

OLIVEIRA, D.; DUARTE, A. Política educacional como política social: uma nova regulação da pobreza. Revista Perspectiva. Florianópolis, v.23, n.2, jul/dez 2005. p.279-301.

OlIVEIRA, D.; ROSAR, M. (Orgs.) Política e Gestão da Educação. Belo Horizonte. Ed. Autêntica, 2002.

OLIVEIRA, F. Um Governo de (Contra-) Reformas. Em: SADER, Emir et al. O Brasil do Real. Rio de Janeiro: EdUERJ, 1996. p. 93-111.

OLIVEIRA, Z de Ramos. A creche no Brasil: Mapeamento de uma trajetória. Revista da Faculdade de Educação. São Paulo, v.1, n. 114, p.43-52, jan/jul 1988.

PENN, H. Quality in Early Childhood Services - An International Perspective. Open University Press. (2011).

PERALTA, M. La calidad en la Educación Parvularia, un tema complejo pero posible en cuanto sea emancipadora. Ciclo de Debates, ¿Qué se sabe sobre la calidad de la Educación Parvularia chilena?, Concepción, Chile. pp. 57-63. abr. 2002.

PERALTA, M. V. Un análisis del desarrollo curricular de la educación parvularia chilena: ¿Cuánto se ha avanzado?. Revista Docencia, Santiago de Chile, 2010. n.46.

PINTO, J. M. R. A política recente de fundos para o financiamento da educação e seus efeitos no pacto federativo. Educação \& Sociedade, v.28, n.100. Campinas, out. 2007 
PURYEAR, J. La accountability en la educación: ¿Qué hemos aprendido? Em: CORVALAN, J.; MCMEEKIN, R. Accountability educacional: posibilidades y desafíos para America Latina a partir de la experiencia internacional. Santiago, Chile. Ed. San Marino. 2006. p.125135

RIBEIRO, B. Qualidade da Educação Infantil no Brasil: tendências e perspectivas. Texto apresentado no Anpae 2014. $\quad$ Disponível em http://www.anpae.org.br/IBERO_AMERICANO_IV/GT1/GT1_Comunicacao/BrunaRibeiro_ GT1_integral.pdf (Acesso 27/02/2017)

. Autoavaliação na Educação Infantil: O desafio da construção compartilhada da qualidade. Revista Veras, São Paulo, v. 6, n. 2, p. 301-332, julho/dezembro, 2016.

ROJAS, Jorge. Historia de la infancia en el Chile republicano 1810-2010. Junta Nacional de Jardines Infantiles, JUNJI. Santiago de Chile. 2010.

ROSEMBERG, F. Educação Infantil pós-Fundeb: avanços e tensões. Em: SOUZA, G. (org.). Educar na Infância: perspectivas histórico sociais. São Paulo: Contexto, 2010. p.171-186.

Panorama da Educação Infantil brasileira contemporânea. Simpósio Educação Infantil: construindo o presente. Anais- Brasilia: UNESCO Brasil, 2003a. $2003 b$.

Sísifo e a educação infantil brasileira. Revista Pro-Posições, v.14, n.1 (40), jan/abr.

A educação pré-escolar brasileira durante os governos militares. Cadernos de Pesquisa, São Paulo, n.82, p.21-30, agosto, 1992.

Educação Infantil pós-FUNDEB: avanços e tensões. Em: Seminário Educar na Infância: perspectivas histórico-sociais. Curitiba. 2007.

Organizações multilaterais, estado e políticas de educação infantil. Cadernos de Pesquisa, n. 115, p. 25-63, março/ 2002a.

SADLER, M. How far can we learn anything of practical value from the study of foreign systems of education. Comparative Education Review, n. 7, p. 307-314, 1964

SANCHEZ, S. La municipalización de la educación, sus antecedentes y proyecciones. Revista de Pedagogia, 1985. n. 280, p.171-172.

SOARES, L. Ajuste neoliberal e desajuste social na América Latina. Petrópolis: Vozes, 2001.

Vozes, 2002.

Os custos sociais do ajuste neoliberal na América Latina. Petrópolis: Editora 
ROSSETTI-FERREIRA, M.; RAMON, F.; SOARES, A. Políticas de atendimento à criança pequena nos países em desenvolvimento. Cadernos de Pesquisa, n. 115, março/ 2002.

SANCHEZ, S. La municipalización de la educación, sus antecedentes y proyecciones. Revista de Pedagogia, 1985. n. 280, p.171-172.

SILVA, I. Democracia e participação na "reforma" do estado. São Paulo: Cortez, 2003. (Coleção Questões da Nossa Época; 103)

SOUZA, D.; MACEDO, L. Reforma do Estado, Descentralização e Municipalização do Ensino no Brasil: A Gestão Política dos Sistemas Públicos de Ensino Pós-LDB 9.394/96. Ensaio de Avaliação de Políticas Públicas Educacionais, Rio de Janeiro. 2004. v.12, n.45, p. 925-944.

TEIXEIRA, F. J. S. O neoliberalismo em debate. Em: TEIXEIRA, F J. S.; OLIVEIRA, M. A. (Orgs.). Neoliberalismo e reestruturação produtiva: as novas determinações do mundo do trabalho. São Paulo: Cortez; Fortaleza: Universidade Estadual do Ceará, 1996.

TOKMAN, A. Radiografía de la Educación Parvularia Chilena: Desafíos y Propuestas. Documentos de Trabajo, Serie de Políticas Públicas UDP, 2010. n.5.

WINTERSBERGER, H. Infancia y ciudadanía: El orden generacional del Estado de Bienestar. Política y Sociedad, v. 43, $\mathrm{n}^{\circ}$ 01, Facultad de Ciencias Políticas y Sociología. Campus de Somosaguas. Madrid, 2006.

ZEMELMAN, H. Algunas reflexiones metodológicas a partir del problema de las investigaciones comparativas. Em: KRAWCZYK, N. R.; WANDERLEY, L. E. (orgs.). América Latina: Estado e reformas numa perspectiva comparada. São Paulo: Cortez Editora/PUC-SP, 2003. p. 83-103.

ZICCARDI, A. (Org.) Pobreza, Desigualdad social y ciudadanía los límites de las políticas sociales en América Latina. Buenos Aires: CLACSO, 2001. 